Florida International University

FIU Digital Commons

$11-14-2000$

\title{
Karl Kraus and the Jewish question: assimilation, language, and persecution in Vienna, 1874-1936
}

Chad Russell Fulwider

Florida International University

Follow this and additional works at: https://digitalcommons.fiu.edu/etd

Part of the History Commons

\section{Recommended Citation}

Fulwider, Chad Russell, "Karl Kraus and the Jewish question: assimilation, language, and persecution in Vienna, 1874-1936" (2000). FIU Electronic Theses and Dissertations. 3426.

https://digitalcommons.fiu.edu/etd/3426

This work is brought to you for free and open access by the University Graduate School at FIU Digital Commons. It has been accepted for inclusion in FIU Electronic Theses and Dissertations by an authorized administrator of FIU Digital Commons. For more information, please contact dcc@fiu.edu. 
FLORIDA INTERNATIONAL UNIVERSITY

Miami, Florida

KARL KRAUS AND THE JEWISH QUESTION: ASSIMILATION, LANGUAGE, AND PERSECUTION IN VIENNA, 1874-1936

A thesis submitted in partial fulfillment of the requirements for the degree of MASTER OF ARTS in HISTORY by Chad Russell Fulwider 2000 
To: Dean Arthur W. Herriott

College of Arts and Sciences

This thesis, written by Chad Russell Fulwider, and entitled Karl Kraus and the Jewish Question: Assimilation, Language, and Persecution in Vienna, 1874-1936, having been approved in respect to style and intellectual content, is referred to you for judgment.

We have read this thesis and recommend that it be approved.

Joseph Patrouch

Benjiman Webb

Mitchell Hart, Major Professor

Date of Defense: November 14, 2000

The thesis of Chad Russell Fulwider is approved.

Dean Arthur w. Herriott College of Arts and Sciences

Interim Dean Samuel S. Shapiro Division of Graduate Studies

Florida International University, 2000 
( Copyright 2000 by Chad Russell Fulwider

All rights reserved. 


\section{DEDICATION}

I dedicate this thesis to my friends and colleagues. Without their patience, guidance, and understanding, this work would not have been possible. Thank you all. 


\section{ACKNOWLEDGMENTS}

I wish to thank the members of my committee, Dr. Mitchell Hart, Dr. Joseph Patrouch, and Dr. Benjiman Webb, for their time, support, advice, and guidance. Their insight and direction has been invaluable. I would also like to thank Dr. Lara Kriegel for her assistance and suggestions for further development of this project. I also extend my thanks to my outside readers for their comments and critiques of this project throughout its development. 


\section{ABSTRACT OF THE THESIS}

KARL KRAUS AND THE JEWISH QUESTION: ASSIMILATION, LANGUAGE, AND PERSECUTION IN VIENNA, 1874-1936

by

Chad Russell Fulwider

Florida International University, 2000

Miami, Florida

Professor Mitchell Hart, Major Professor

This study examines the Viennese satirist Karl Kraus and his responses to the "Jewish Question" and antisemitism. Through a comprehensive analysis of his major works, this project reveals Kraus's underlying views on Jewish identity and his ideas for resolving the "Jewish Question." Kraus attacked acculturated German-speaking Jews for "failing" to assimilate into society. In his mind, the bourgeois Jewish intellectuals had retreated into a "transparent ghetto" of aesthetic values, literary expression, and capitalist-materialism, represented by the "Jewish" press. For Kraus, anti-Semitism persisted because the Jews maintained their status as "Jews," and therefore could not assimilate into Viennese society. His solution to this "faulty" assimilation was to renounce all ties to Judaism and adopt Viennese culture completely. 
CHAPTER

I. AN INTRODUCTION TO THE SATRICIAL WORLD OF KARL KRAUS.1

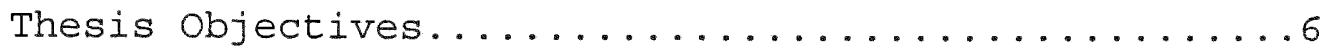

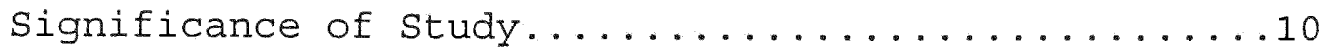

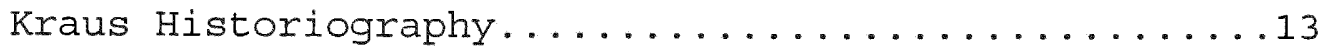

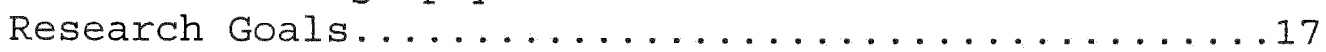

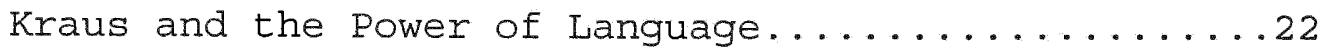

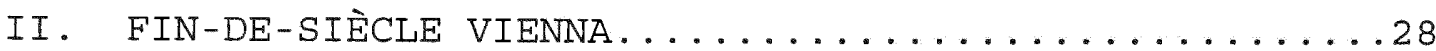

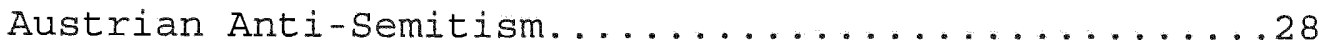

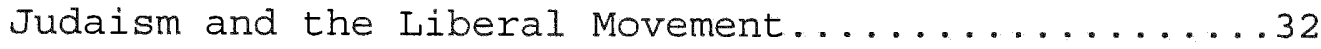

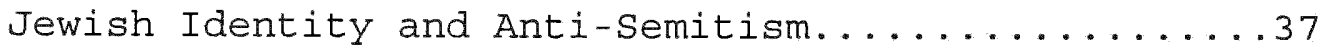

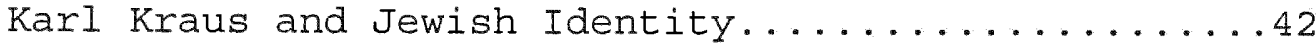

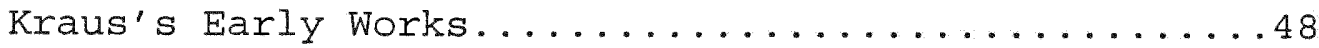

III. KARL KRAUS AND THE "JEWISH QUESTION"............55 Jewish Responses to the "Jewish Question"........55 Karl Lueger and the Christian Socialists..........58

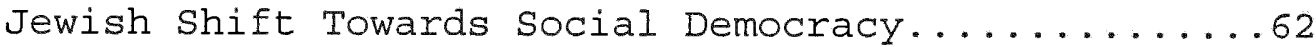

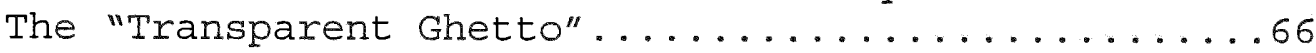
Karl Kraus and the "Jewish Question"............75 Karl Kraus: "Self-Hater" or "Modern Day Prophet"...93

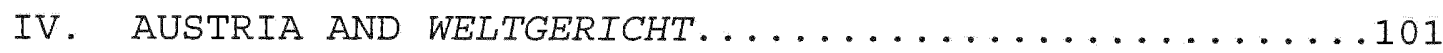

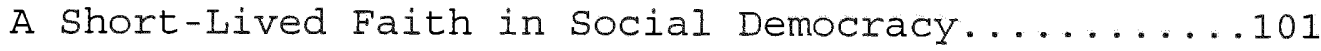
The Dreyfus Affair and the Krausian Reaction......107

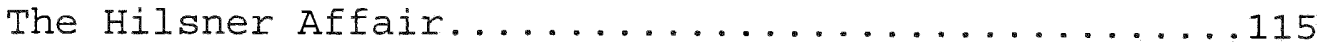

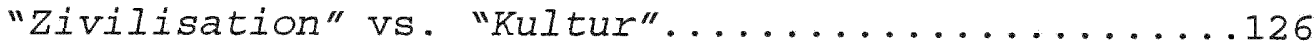
Kraus's Hope for Judaism and Humanity............132

V. CONCLUSION: THE LAST DAYS OF MANKIND................... Kraus's Evolution - The Expiration of the Word....139 Karl Kraus and the "Third Force"..............145

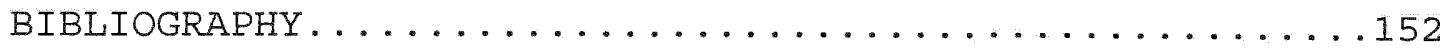




\title{
Chapter I: An Introduction to
}

\section{the Satirical World of Karl Kraus}

\author{
"People don't understand German, but I can't tell them \\ things in Journalese."1 \\ "Lord, forgive them, for they know what they do!" 2
}

The Viennese satirist Karl Kraus once declared that according to the 1911 census, "Vienna had 2,030,834 inhabitants, that is $2,030,833$ souls and myself." ${ }^{3}$ This bold statement demonstrates Kraus's self-imposed detachment from Viennese society. Convinced of his own uniqueness and unwilling to be labeled or categorized, Kraus launched his own personal campaign to attack all that he perceived to be wrong in Viennese society.

Kraus's campaign involved attacking acculturated, westernized German-speaking Jews through his particular brand of bitter and piercing satire. At the same time, he struggled with his own Jewish identity in the anti-Semitic

\footnotetext{
${ }^{1}$ Karl Kraus, Half-Truths and One and a Half Truths:
} Karl Kraus, Selected Aphorisms, edited and translated by Harry Zohn (Montreal: Engendra Press, 1976), 68.

${ }^{2}$ Ibid, 124

${ }^{3}$ "Die Volkszählung hat ergeben, daß Wien 2030834 Einwohner hat. Nämlich, 2030833 Seelen und mich. "Harry Zohn, "Karl Kraus: "Jüdischer Selbsthasser " oder "Erzjude"?" Modern Austrian Literature 8 (1975) : 1. From Die Fackel, 315-316, January 26, 1911, 13. 
climate of Vienna. Kraus believed that "corrupt" and "liberal" Jews were dragging Austrian and German culture into a precipitous state of decline. To measure this decline, Kraus brought the yardstick of language to bear against his opponents. By quoting directly from his counterparts and then explaining their underlying paradoxes or hypocrisies, Kraus sought to revolutionize language and by extension, to rescue the Austria he loved - by teaching the Viennese population to read with careful scrutiny. Though ultimately doomed to failure, Kraus devoted his life to a one-man crusade to revive the "lifeless" body of the German language. ${ }^{4}$

Born in Jičin, Bohemia in 1874, the young Kraus and his family moved in 1877 to Vienna. He lived there until his death in 1936. Kraus's father, a devout Jew, was the owner of a prosperous paper manufacturing company that provided a comfortable way of life for his family. Kraus entered the University of Vienna in 1892, where he studied law, philosophy, and German literature. He left, however, in 1898 before completing a degree. During his time at the

${ }^{4}$ One of Kraus's aphorisms reads "I put my pen to the Austrian corpse because I persist in believing there is life in it." Kraus, Half-Truths and one and a Half Truths, 101. 
university, Kraus wrote book reviews and satirical

sketches, some of which were published in periodicals and newspapers in both Germany and Austria. ${ }^{5}$

Kraus's first major satirical work was Die demolirte Literatur, which appeared origianlly in the Wiener Rundschau and subsequently as a pamphlet in 1896. The piece, which lampooned the "Jung Wien" circle of intellectuals and authors in Vienna, marked Kraus as a distinguished social critic. Three years later, Kraus founded Die Fackel (The Torch), a satirical journal that he published from 1899 to 1936. Although Kraus originally accepted submissions from other authors, from 1911 onward he wrote and published Die Fackel single-handedly. Kraus once commented, "I no longer have collaborators. I used to be envious of them. They repelled those readers whom I want to lose myself." ${ }^{6}$ Again, this demonstrates Kraus's sense of isolation from the Viennese public and his mission

\footnotetext{
${ }^{5}$ Kraus published articles in Die Gesellschaft (Leipzig), Magazin für Literatur (Berlin), Neue literarische Blätter (Bremen), and the Viennese Liebelei, Die Wage, Wiener Literatur-Zeitung, Wiener Rundschau, and Die Neue Freie Presse. Harry Zohn, Karl Kraus and the Critics, (Columbia: Camden House, 1997), xi.

${ }^{6}$ Karl Kraus, Half-Truths and One and a Half Truths, 4. out of the 30,000 pages of Die Fackel, Kraus is responsible for writing just over 25,000.
} 
to attack those elements he saw as detrimental. "There are $2,030,833$ souls and myself;" the one-man crusade had begun in earnest.

In his voluminous works, ${ }^{7}$ Kraus focused his criticism on those elements of society that he felt were contradictory or hypocritical to the cultural norms of Vienna in the early twentieth century. Kraus believed that capitalist-materialism, anti-Semitism, linguistic corruption and the misuse of language, and the wild exaggerations of the media were all contributing to a cultural decline in Vienna during this period. He claimed that "once upon a time the actors were genuine and the decorations of cardboard; nowadays the decorations do not give rise to doubt - and the actors are of cardboard." ${ }^{8}$ By this Kraus meant that while Austro-German authors and

${ }^{7}$ Kraus's works, not including the 922 numbers of Die Fackel, were bound and reissued by his longtime friend, Heinrich Fischer. Karl Kraus, Werke. Edited by Heinrich Fischer, 14 vols. (Munich 1952-1967). Comprised of the following volumes: I Die dritte Walpurgisnacht (1952), II Die Sprache (1954), III Beim Wort genommen (1955), IV Widerschein der Fackel (1956), V Die letzten Tage der Menschheit (1957), VI Literatur und Lüge (1958), VII Worte in Versen (1959), VIII Untergang der Welt durch schwarze Magie (1960), IX Unsterblicher Witz (1961), X Mit vorzüglicher Hochachtung (1962), XI Sittlichkeit und Kriminalität (1963), XII Die chinesische Mauer (1964), XIII Weltgericht (1965), XIV Dramen (1967).

${ }^{8}$ Kraus, Half-Truths and one and a Half Truths, 50. 
playwrights used to create genuine works of art, as exemplified in the operas of offenbach and the plays of Nestroy, the current writers now recycled old plots and dialogues, cloaking them in aesthetic ideals and grand artistic illusions.

In Kraus's view, this decline culminated with the catastrophic outbreak of the First World war. The tragic effects of this war were vividly depicted in his epic drama Die letzten Tage der Menschheit. This drama satirizes the manipulation of the public by the press in an apocalyptic warning of impending disaster. Moreover, despite having been born into a Jewish family, Kraus blamed this decline in part on the purported influence of negative "Jewish" forces in society and culture. Kraus arguably believed that a revival of the ideals of German Kultur was possible, and that such a revival could take place through the creation of a "critical enlightenment" of the reading public with his satire. These newly enlightened groups could then reverse the decline which Kraus perceived as resulting from the "Jewish" corruption of language."

${ }^{9}$ Wilma Abeles Iggers, Karl Kraus: A Viennese Critic of the Twentieth Century (The Hauge: Martinus Nijhoff, 1967), 94 . 


\section{Thesis Objectives}

Through a comprehensive analysis of Kraus's major works, particularly Die Fackel (The Torch) and his early works, this essay will examine how Kraus was influenced by his view of the Jews and his responses to the "Jewish Question" "in fin-de-siècle Vienna. Kraus's views will be placed in a broader context through analysis of the recent literature on Jewish identity and Jewish reactions to antiSemitism. ${ }^{10}$ Was Kraus an example of a "Jüdischer Selbsthasser" ("Jewish self-hater") or was he a self-

${ }^{10}$ Some of the works to be consulted are: Steven $E$. Aschheim, Brothers and Strangers: The East German Jew in German and German Jewish Consciousness, 1800-1923 (Madision: University of Wisconsin Press, 1982) ; idem., Culture and Catastrophe: German and Jewish Confrontations with National Socialism and Other Crises (New York: New York University Press, 1996); Jonathan Frankel and Steven Zipperstein, eds., Assimilation and Community: The Jews in nineteenth-century Europe (Cambridge: Cambridge University Press, 1992) ; Sander Gilman, Jewish SelfHatred: Anti-Semitism and the Hidden Language of the Jews (Baltimore: Johns Hopkins University Press, 1986) ; Brigette Hamann, Hitler's Vienna: A Dictator's Apprenticeship, translated by Thomas Thornton (Oxford: Oxford University Press, 1999) ; Sandra Harding, ed. The Racial Economy of Science: Toward a Democratic Future (Bloomington: Indiana University Press,1993) ; Peter Pulzer, The Rise of Political Anti-Semitism in Germany and Austria (New York, London: John Wiley and Sons, 1964); Jack Wertheimer, Unwelcome Strangers: East European Jews in Imperial Germany (Oxford: Oxford University Press, 1987) ; Robert Wistrich, The Jews of Vienna in the Age of Franz Joseph (Oxford: Oxford University Press, 1989). 
ostracized "Erzjude" ("arch-Jew," in the sense of an Old Testament prophet), seeking to come to terms with his own identity in the assimilated Viennese-Jewish environment? Due to the extraordinary complexity of his thought, Kraus provides a unique insight into the plight of acculturated Jews who sought to gain acceptance into the particularly anti-Semitic environment of Vienna. His own radical response is also a vivid example of the difficulties and complexities of identity, nationalism, and the sense of a "community" during this period in Austrian history.

This essay will systematically analyze Kraus's views on anti-Semitism and the "Jewish Question"." Kraus's personal struggle with his Jewish identity can be understood within the context of his overall condemnation of European society and his perception of the failure of acculturated Jews to assimilate completely into Austrian and German societies. ${ }^{11}$ For Kraus, powerful and influential

${ }^{11}$ Initially, Kraus's polemic was directed against the ruling classes who had forced Europe into war. Later, his focus would be upon the "enemy within," a phrase from Die Fackel in May 1916. This term is further explored in the Grumbler's second monologue in Act II, scene 10 of Die letzten Tage. Kraus links anti-Semitic rhetoric with this notion by emphasizing that the "enemy within" has a "crooked nose" (Krummnas). Karl Kraus, Die letzten Tage der Menschheit: Tragödie in fünf Akten mit Vorspiel und Epilog (München: Kösel-Verlag, 1957), 252. See also Edward Timms, Karl Kraus, Apocalyptic Satirist: Culture 
Jewish intellectuals were fundamentally responsible for the corruption of culture and society because they reinforced negative Jewish stereotypes through their misuse of language. Jewish businessmen and financiers "manipulated" the capitalist economy and thereby contributed to the materialist-consumer culture, thus stimulating hatred against the Jews in general through their economic success. In his writings, Kraus sought to provoke his readers into action so that they would learn to think for themselves. Through his satire he hoped to expose the hypocrisy of Viennese society and the malicious intents of the "Jewish" liberal press. By quoting directly from his opponents, Kraus revealed their inherent contradictions and ambiguities. Rather than accept the wild exaggerations, financial advice, and opinions of the press and politicians at face value, the reading public should learn to discern solid facts from "cardboard" fiction.

For example, in Die letzten Tage der Menschheit Kraus contrasts the different perceptions of the Viennese people through the characters der Nörgler (Grumbler) and der Optimist. The Grumbler finds the bad in everything and

and Catastrophe in Habsburg Vienna (New Haven: Yale University Press, 1986), 373. 
constantly tries to convince the Optimist of the dangers of the war, of materialism and the failure of liberalism, and of the pervasive manipulation of the press. Kraus blames these conditions on the assimilated and corrupt liberal Jews. The Grumbler is a focused projection of Kraus's views, but the character does not reflect the full range of Kraus's identity. The Grumbler is instead utilized as a literary instrument that Kraus manipulates to illustrate his points with precise clarity. ${ }^{12}$

In contrast to the Grumbler, the Optimist is an intelligent and educated member of Viennese society, but

${ }^{12}$ Although many Kraus scholars assume that "the Grumbler is, of course, Kraus himself" (Harry Zohn, Karl Kraus, New York: Twayne Publishers, 1971, 73), this is an oversimplification of the complexities of the character. In the Grumbler's dialogues, Kraus's own conservatism, as reflected in Die Fackel during this same period, is significantly downplayed, while the comments on the negative effects of capitalism and militarism are highly emphasized. Also, the one-sidedness of the Grumbler's character is significant. The Grumbler remains in Vienna and is committed to showing the hypocrisy of the war; whereas, Kraus himself traveled frequently during this period and was more concerned with wider social and political issues. The Grumbler also assumes a desperate polemic with the Optimist, while Kraus's other works are much more carefully balanced and rational. The essential significance of the Grumbler is as a character in the play, not as a mirror image of Kraus. Although Kraus incorporates important aspects of his views into the Grumbler's dialogues, the character is ultimately "shaped by an overriding literary purpose." Timms, Karl Kraus, Apocalyptic Satirist, 391, 388-391. 
one who is socially and politically naive. It is this "typischer Wiener," as represented by the Optimist, whom Kraus hoped to enlighten with his satire, thereby reversing the cultural decline he saw in Viennese society. Although the Optimist does eventually comprehend the Grumbler's warnings and see the "true reality" around him, Kraus himself never succeeded in creating the "critical enlightenment" he sought for his readers. He continued to publish his journal until his death in 1936. Had he lived longer, Kraus would have soon been forced to discontinue Die Fackel because of declining readership and the radicalization of the political systems of Germany and Austria. Sadly, his "Torch" was mostly forgotten until after the second world War.

\section{Significance of Study}

The fundamental strength of Kraus's work derives from his methodology applied on a massive scale. His collected works fill fourteen substantial volumes. Additionally, there are thirty-seven volumes of Die Fackel, comprised of nine hundred and twenty two numbers. ${ }^{13}$ The drama Die

${ }^{13}$ Kraus inherited a substantial sum of money at his father's death in 1900. This allowed him to devote all his time to his writing, and the financial independence to 
letzten Tage der Menschheit is nearly eight hundred pages in length and consists of some two hundred fifty-nine scenes. Its list of characters includes approximately five hundred figures. Much of Kraus's writings consist of quotations, of words, songs and phrases that were spoken or written by others in his day. In the preface of Die letzten Tage, Kraus states:

Die unwahrscheinlichsten Taten, die hier gemeldet werden, sind wirklich geschehen; ich habe gemalt, was sie nur taten. Die unwahrscheinlichsten Gespräche, die hier geführt werden, sind wörtlich gesprochen worden; die grellsten Erfindungen sind Zitate. Sätze, deren Wahnwitz unverlierbar dem ohr eingeschrieben ist, wachsen zur Lebensmusik. ${ }^{14}$

The most improbable deeds reported here really happened. I have reported only what was done. The most improbable conversations that are carried on here were spoken word for word. The most glaring inventions are quotations. Sentences whose insanity is indelibly imprinted on the ear grow into a melody that stays with one for life.

Rather than create fictional characters or imagined dialogues, Kraus absorbed the attitudes and slogans around

criticize others without regard for the consequences. Timms, Karl Kraus, 36.

${ }^{14}$ Karl Kraus, Die letzten Tage der Menschheit, 9. A textual analysis of Die letzten Tage reveals that at least half of the dialogue in the drama consists of verbatim newspaper excerpts, primarily from the pages of the Neue Freie Presse. Richard Grunberger, "Jews in Austrian Journalism" in The Jews of Austria, edited by Josef Frankel (London: Valentine, Mitchell, \& Co., 1967), 91. 
him. He often used real people or thinly veiled representatives as vehicles for his damning social critiques. Kraus would quote verbatim from his sources and then deconstruct them to reveal the underlying contradictions and hypocrisies. This unique approach gives his work a documentary quality. Kraus showed the inconsistencies and conflicts within the words and conversations themselves. This was the most devastating aspect of his satire.

Only a small number of Kraus's works have been translated. Frederick Ungar and Harry Zohn have rendered portions of Die letzten Tage der Menschheit and other selected works in the mid-1970s, but both of their translations are heavily edited and abridged and amount to only an introduction into the world of Karl Kraus. The difficulty in translating Kraus arises from his precise use of language. He was an expert at puns and word play and intentionally constructed sentences that could be interpreted in multiple, often-contradictory ways. Additionally, Kraus often inserted "Jewish" pronunciations - mauscheln or jüdeln - into his works to portray certain cultural stigmas or prejudices or to demonstrate how other 
Jewish writers propagated negative Jewish stereotypes through their misuse of language.

This study will analyze Kraus's use of language and critical satire to reveal his views on Jewish identity and his responses to the "Jewish Question." German scholars have attempted to address similar issues in relation to Kraus, but the subject has received little attention in English. By building on the work of other scholars and with careful attention to Kraus's own writings, the current study will help to explain Kraus's views on Jews and Jewish identity - and the ways that they were refracted through his satire - to an English-speaking audience.

\section{Kraus Historiography}

Though Kraus has received a great deal of attention in Austria and Germany since his death, he is largely unknown outside of Europe. A few German works were written about Kraus during his lifetime: Robert Scheu's Karl Kraus, Leopold Liegler's Karl Kraus und sein Werk, and Berthold Viertel's Karl Kraus: Ein Charakter und die Zeit. ${ }^{15}$ Kraus is also discussed in Theodor Lessing's Der jüdische

${ }^{15}$ Robert Scheu, Karl Kraus (Vienna: Jahoda \& Siegel, 1909) ; Leopold Liegler, Karl Kraus und sein Werk (Vienna: Richard Lanyi, 1920) ; Berthold Viertel, Karl Kraus: Ein Charakter und die Zeit (Dresden: Kämerer, 1921). 
Selbsthaß, in which he is labeled as "the shining example of Jewish self-hatred."16 After World War II, a few studies were written in English. However, these works on Kraus lack a focused analysis of his Jewishness or his views on the "Jewish Question." In the direct aftermath of Hitler and the Holocaust, such a study would arguably be inflammatory and controversial by its very nature.

Wilma Iggers's Karl Kraus: A Viennese Critic of the Twentieth Century devotes a chapter to Kraus's antiSemitism. However, this "virtually unchanged" dissertation merely condemns him from a moral perspective and fails to analyze Kraus's response to his own Jewishness. ${ }^{17}$ In a subsequent article, Iggers still avoids the "Jewish Question," but she does point out some of Kraus's multiple and varied contradictions. ${ }^{18}$ In seeking to promote social change and to demonstrate the hypocrisy of Vienna, Kraus attacked a wide variety of subjects. He spoke out against

${ }^{16}$ "das leuchtendste Beispiel des jüdischen Selbsthasses, "Theodor Lessing, Der jüdische Selbsthaß, (Berlin, Jüdischer Verlag, 1930), 43.

${ }^{17}$ Iggers, Karl Kraus: A Viennese Critic of the Twentieth Century (1967). First published as a Ph.D. dissertation for the University of Chicago in 1952. Zohn, Karl Kraus and the Critics, 116.

${ }^{18}$ Wilma Abeles Iggers, "Karl Kraus and his Critics," Modern Austrian Literature 8 (1975) : 26-47. 
Jewish support of Dreyfus in the late 1890s, advocated the rights of prostitutes and homosexuals during the 1900s, wrote as an ardent pacifist during the war, attacked the Christian Socialists throughout his writings, and came to support Dollfuss against the Nazis in 1934. From 1914 onward, Kraus was a committed pacifist. He attended an international peace conference that was held in Amsterdam in 1932. Romain Rolland, Henri Barbusse, Frans Masereel, Albert Einstein, Heinrich Mann, John Dos Passos, Upton Sinclair, and Maxim Gorky, among others were present at the conference, and Kraus was the only Austrian representative. ${ }^{19}$ This is evidence of his belief in promoting a peaceful solution to the problems and the "decline" of European society as a whole, while at the same time seeking to create an enlightened liberal community.

General interpretative works also appeared in the 1960s and 1970s, but they likewise neglect to address the relationship between Kraus and anti-Semitism. ${ }^{20}$ The most

${ }^{19}$ Zohn, Karl Kraus, 23.

${ }^{20}$ Frank Field's The Last Days of Mankind: Karl Kraus and his Vienna (New York: St. Martin's Press, 1967) is a basic summary of Kraus's work, if overly praise-laden. Harry Zohn's Karl Kraus (New York: Twayne Publishers, 1971) details Kraus's life within the context of Vienna. Zohn also published a Kraus reader in English, In These Great Times: A Karl Kraus Reader, edited by Harry Zohn, 
comprehensive study of Kraus's overall work to date is Edward Timms's Karl Kraus, Apocalyptic Satirist: Culture and Catastrophe in Habsburg Vienna. ${ }^{21}$ Timms reviewed the first performance of Die letzten Tage der Menschheit in Vienna in 1964 and presents a well-researched view of Kraus's overall life. However, his work does not attempt to uncover Kraus's views of Jews or of anti-Semites. In fact, John Theobald's The Paper Ghetto: Karl Kraus and Anti-Semitism, is the only study in English to even address the evolution of Kraus's perception of the Jews and of his anti-Semitism. ${ }^{22}$ This study, however, does not place Kraus within his environment, but seems to label him as "Kraus, the Jew" against other Jews. Other works have focused on Kraus's satirical journal Die Fackel, his use of language,

translated by Joesph Farby, Max Knight, Karl F. Ross, and Harry Zohn (Montreal: Engendra Press, 1976). Zohn's most recent contribution is a general critique of the literature on Kraus, Karl Kraus and the Critics (Columbia: Camden House, 1997).

${ }^{21}$ Edward Timms, Karl Kraus, Apocalyptic Satirist: Culture and Catastrophe in Habsburg Vienna (New Haven: Yale University Press, 1986) ; idem., "The Last Days of Mankind: A Neglected Play," Times (London), 22 June 1964, p. 14 .

${ }^{22}$ John Theobald, The Paper Ghetto: Karl Kraus and Anti-Semitism (Frankfurt am Main: Peter Lang, GmbH, 1996). 
or his works in general and have avoided the issue of antiSemitism altogether.

\section{Research Goals}

In order to reveal Kraus's responses to his own Jewish identity as well as the "Jewish Question," three major issues must be addressed. First, there is the idea of a "liberal materialism," often associated during this period with acculturated Jews. Most Central European Jews during this time embraced liberalism in an effort towards assimilation and acceptance into society. ${ }^{23}$ Those who succeeded in assimilating often rose to prominent positions in society and were viewed as materialistic and exploitative by anti-semites.

Kraus, himself from an upper middle-class Jewish family, was acutely aware of racial and ethnic prejudices in Viennese society. In attempting to dissociate himself from his Jewish heritage, Kraus offered the stereotypical "Eastern" Jew who embraced Zionism or refused to assimilate as "the Other" or "bad" Jew. As an assimilated, educated,

${ }^{23}$ This is a well-documented phenomenon. See Jonathan Frankel and Steven J. Zipperstein, eds., Assimilation and Community; Jacob Katz, From Prejudice to Destruction; Peter Pulzer, The Rise of Political Anti-Semitism; Jack Wertheimer, Unwelcome Strangers: East European Jews in Imperial Germany. 
and cultured Jew, Kraus's response to what John Murray Cuddihy has called "the ordeal of civility" was to attack. the purported elements of Jewishness that he saw as fostering anti-Semitism: those individuals of eastern Europe who would not or could not assimilate. ${ }^{24}$ Cuddihy asserted that Jewish intellectuals were caught between two separate worlds, one that was the religious, Orthodox Judaism of the East, and the assimilated, secular world of the West. The adopted "Gentile host culture" forced the Jewish intellectual to experience a "cultural shame and awkwardness, guilt, and the 'guilt of shame'." Thus, according to Cuddihy, the focus of the assimilated Jew was the "public behavior of his fellow Jews, the Ostjuden."25 Additionally, Kraus believed that acculturated Jews had failed to assimilate fully into society. By maintaining and utilizing their Jewish identity when it was advantageous, these Jews thus arguably contributed to anti-

${ }^{24}$ John Murray Cuddihy, The Ordeal of Civility: Freud, Marx, Levi-Strauss, and the Jewish Struggle with Modernity (New York: Basic Books, 1974). Cuddihy's argument is highly controversial. He has been accused of using antisemitic ideas and stereotypes to reach his conclusions. Nevertheless, Cuddihy's idea of an "ordeal" of assimilation closely parallels Kraus's conception of a struggle towards assimilation that involves a rejection of Jewish identity and a critical attitude towards the ostjuden in Vienna.

${ }^{25}$ Ibid, 4. 
Semitism. This analysis of Kraus's works will show that ultimately he believed the only way to eliminate antiSemitism was complete assimilation on the part of the Jews and the rejection of all things Jewish. ${ }^{26}$

The second point to be addressed is Kraus's concern with language and its "corruption" by journalists through the mass production and circulation of newspapers, the popularity of the feuilleton ${ }^{27}$ or cultural essay, and the power of the media to inspire hysteria through the printing presses. ${ }^{28}$ Kraus felt that language, literature, and intellectual thought were being replaced by clichés, the

${ }^{26}$ Kraus coined the term "paper ghetto" to describe the world that assimilated Jews in Vienna had constructed for themselves, "whose boundaries were not physical walls but boundaries of perception created by newspapers which shielded them from the broader reality and, contrary to the inherent aim of assimilation, set them apart as a clique, and a target for anti-Semitism." John Theobald, The Paper Ghetto: Karl Kraus and Anti-Semitism, 16.

${ }^{27}$ The feuilleton, popularized in the German-speaking world primarily by Heinrich Heine, was the most important section of the daily paper from many aesthetes and cultural aficionados in Vienna. Such essays mixed fact and opinion with cultural stereotypes to shape the views of the reader.

28 "One ought to acknowledge the significance for mankind of the simultaneous invention of gunpowder and printer's ink." Kraus, Half-Truths and One and a Half Truths, 82 . 
feuilleton, and editorials. ${ }^{29}$ Claiming to be an apolitical conservative, Kraus attempted to distance himself from strong political ideologies, particularly those expressed in Die Neue Freie Presse and other liberal Jewish publications. Aside from being the most influential newspaper of the Habsburg Empire, Die Neue Freie Presse was for Kraus the symbol of "negative Jewish forces" spreading across Europe.

Kraus regarded the majority of the Viennese middleclass as mere mouthpieces for the "Jewish" newspapers. Such journalism fed the mind by supplying all moral, political, and religious views, along with disinformation and cultural stereotypes. To Kraus, "the feuilleton destroyed both the objectivity of the situation and the creative fantasy of the writer...it both reduced the essayist's creativity to the level of word-manipulation and prevented the reader from making any rational assessment of

29 "Heine, der der deutschen Sprache so sehr das Mieder gelockert hat, daß heute alle Kommis an ihren Brüsten fingern können." (Heinrich Heine so loosened the bodice of the German language that today every little salesman can fondle her breasts.) Kraus, Half-Truths and one and a Half Truths, 65 . 
the facts of the case." ${ }^{30}$ The press misrepresented the facts for ulterior motives. Without the accurate reporting of information and events, public opinion became a complete fabrication of the press. Kraus's only hope was that mankind "would become so stupid and primitive from reading newspapers that it would have to learn the first elements of reading and thinking over again, and then have learned its lesson." 31

Finally, the third point is Kraus's view of Jewish intellectuals as the "true" cause of anti-semitism and as traitors to the social order. He believed they were interested only in notions of power, nationalism, and imperialism. Kraus blamed "Jewish materialism" for provoking the First World War for financial gain. The intellectuals' support of nations and empires would ultimately lead to catastrophe. During the war, Kraus condemned war profiteers, the press and the propaganda machine, intellectuals (particularly Jews) who glorified the war, and the generals responsible for the carnage and

${ }^{30} \mathrm{All}$ an Janik and Stephen Toulmin, Wittgenstein's Vienna (New York: Simon and Schuster, 1973), 79, 45-46, $78-81$.

${ }^{31}$ Iggers, Karl Kraus, $94-95$. 
destruction throughout the course of the war. ${ }^{32}$ For Kraus, these groups represented the negative "Jewish" forces that were destroying society through capitalism, "Jewishmaterialism," and the corruption of language.

\section{Kraus and the Power of Language}

Language became a crucial political issue in the aesthetic and cultured environment of Vienna. National and patriotic sympathies are connected to language and Iinguistic usage. ${ }^{33}$ In the Austrian half of the Dual Monarchy, there were seven official nationalities, of which Germans were a small majority. ${ }^{34}$ In the Hungarian lands of the Empire, Germans ranked second in terms of population, significantly outnumbered by Magyars. Throughout the

${ }^{32}$ Various intellectual targets of Kraus's satire include Gerhart Hauptmann, Hugo von Hofmannsthal, Stefan Zweig, Rainer Maria Rilke, Heinrich Heine, Theodor Herzl, Sigmund Freud, and Heinrich Friedjung. Kraus's favorite target was Die Neue Freie Presse's editor-in-chief, Moritz (Maledikt) Benedikt, whom Kraus caricatured as "Lord of the Hyenas," feasting on the fallen carcasses of Austrian soldiers in Die letzten Tage der Menschheit.

${ }^{33}$ For a complete discussion on the complexities of "German" nationality and "Austrian" Citizenship, see Andrew G. Whiteside, The Socialism of Fools: Georg Ritter von Schönerer and Austrian Pan-Germanism (Berkeley, Los Angeles, London: University of California Press, 1975), 942 . 
Habsburg Empire, there were twelve recognized national groups. The following table illustrates the tenuous numerical majority held by the German-speaking population during the last decades of the Habsburg Empire.

\begin{tabular}{|c|c|c|c|c|}
\hline $\begin{array}{l}\text { Nationality } \\
\text { statistics by } \\
\text { Percentage }\end{array}$ & 1880 & 1890 & 1900 & 1910 \\
\hline \multicolumn{5}{|l|}{$\begin{array}{l}\text { Cisleithanian } \\
\text { Austria }\end{array}$} \\
\hline Germans & 36.8 & 36.1 & 35.8 & 35.6 \\
\hline $\begin{array}{l}\text { Czechs and } \\
\text { Slovaks }\end{array}$ & 23.8 & 23.3 & 23.2 & 23.0 \\
\hline Poles & 14.9 & 15.8 & 16.6 & 17.8 \\
\hline Ruthenians & 12.8 & 13.2 & 13.2 & 12.6 \\
\hline Serbo-Croats & 2.6 & 2.8 & 2.8 & 2.6 \\
\hline Rumanians & 0.9 & 0.9 & 0.9 & 1.0 \\
\hline \multicolumn{5}{|c|}{$\begin{array}{l}\text { Lands under } \\
\text { Hungarian Crown }\end{array}$} \\
\hline Magyars & 41.2 & 42.8 & 45.4 & 48.1 \\
\hline Germans & 12.5 & 12.2 & 11.0 & 19.8 \\
\hline Slovaks & 11.9 & 11.1 & 10.5 & 9.4 \\
\hline Rumanians & 15.4 & 14.9 & 14.5 & 14.1 \\
\hline Ruthenians & 2.3 & 2.2 & 2.2 & 2.3 \\
\hline Croats & 9.0 & 8.7 & 8.8 & na \\
\hline Serbs & 6.1 & 5.5 & 5.3 & na \\
\hline \multicolumn{5}{|l|}{$\begin{array}{l}\text { Empire Totals } \\
\text { for } 1910\end{array}$} \\
\hline Germans & & & & 23.9 \\
\hline Magyars & & & & 20.2 \\
\hline Czechs & & & & 12.6 \\
\hline Slovaks & & & & 3.8 \\
\hline Croats & & & & 5.3 \\
\hline Serbs & & & & 3.8 \\
\hline Poles & & & & 10.0 \\
\hline Ruthenians & & & & 7.9 \\
\hline Rumanians & & & & 6.4 \\
\hline slovenes & & & & 2.6 \\
\hline Italians & & & & 2.0 \\
\hline
\end{tabular}

Source: Kann, A History of the Habsburg Empire, 606-607.

${ }^{34}$ Robert A. Kann, A History of the Habsburg Empire, 1526-1918, (Berkeley: University of California Press, 1974), 606 . 
In fact, despite having political control, the Germanspeaking aristocracy faced stiff competition from the Czech-speaking groups, particularly in the East. The American satirist Mark Twain was in Vienna in 1897 when two decrees were introduced into Parliament. These decrees called for the Czech language to be made equal to German for official uses in Bohemia and Moravia. Twain documents the riots that followed the proposal and the complete ineffectiveness of the parliamentary government in the Empire. He also notes the violence exhibited towards Jews. According to Twain, sixty policemen entered Parliament by force and removed the Social Democrats who had stormed the podium. As a result,

the Badeni government ${ }^{35}$ came down with a crash; there was a popular outbreak or two in Vienna: there were three or four days of furious rioting in Prague, followed by the establishing there of martial law; the Jews and Germans were harried and plundered and their houses destroyed; in other Bohemian towns there was rioting - in some cases the Germans being the rioters, in others the Czechs - and in all cases the Jew had to roast, no matter which side he was on...public opinion believes that parliamentary government and the constitution are actually threatened with extinction, and that the permanency of the

${ }^{35}$ Count Badeni was governor of Galicia and served as Prime Minister from 1895-1897. John W. Mason, The Dissolution of the Austro-Hungarian Empire, 1867-1918, $2^{\text {nd }}$ ed., (London and New York: Longman, 1997), 39-40. 
monarchy itself is a not absolutely certain thing! ${ }^{36}$

The Neue Freie Presse covered these riots extensively with front-page stories attacking the "anti-Semitic silence;" in these stories Czech and German victims were mourned, while "no mention was made of the real victims, the Jews." 37

In this unique framework of fin-de-siècle Austria, grammar and correct word usage took on political, social, and ethical connotations. The arguable misuse of language, on the part of the Jews, allowed them to be seen as nonpatriotic and hence a threat to the nation. According to J.P Stern, "the whole complex of anti-semitic attitudes is

${ }^{36}$ Mark Twain, "Stirring Times in Austria," Harper's New Monthly Magazine (1897), 540. This particular article also "stirred" up a wave of controversy, and Twain published a second article to clarify his statements with regard to the Jews in the first article. Mark Twain, Concerning the Jews (Philadelphia: Running Press, 1985), first published in Harper's New Monthly Magazine, 1897.

${ }^{37}$ For Kraus, this was simply further proof that liberal Jews drew attention to themselves and to other Jews; this only encouraged anti-Semitism and anti-Jewish violence. Die Neue Freie Presse, 24 October 1899, 1 ; quoted in Steven Beller, "The Hilsner Affair: Nationalism, AntiSemitism and the Individual in the Habsburg Monarchy at the Turn of the Century," in Robert B. Pynsent, ed., Pynsent, T.G. Masaryk (1850-1937) Volume 2 Thinker and Critic (New York: St. Martin's Press, 1989), 60-61. 
steeped in language consciousness and is unthinkable without it." ${ }^{38}$

During his lifetime, Kraus seemed to believe that the cause of the multifarious problems of the world did not lie within human nature, but rather with "that which deadened the soul most, the unconscientiously used and distributed word." ${ }^{39}$ The newspapers acted as candy, continually malnourishing the mind, if not destroying it outright. ${ }^{40}$ They supplied all the moral, political, and religious views, all knowledge, and all feeling to their readers. Without the reliable transmission of information, or simply through the unquestioning acceptance of reported "facts," public opinion became insignificant, a mere puppet of the media.

For Karl Kraus, it was language that defined mankind as a whole. He saw language as the moral index of society and used it to gauge the cultural strength or weakness of a western society. It is from this concern regarding

${ }^{38}$ J.P. Stern, "Words Are Also Deeds: Some Observations on Austrian Language Consciousness," New Literary History 12 (1981) : 509.

${ }^{39}$ Iggers, Karl Kraus, $94-95$.

40 "Das ist der Krieg---C'est la guerre---Das ist die Zeitung!" Karl Kraus, Untergang der Welt durch Schwarze Magie (München: Kösel-Verlag, 1960), 363. 
language that his vilification of the press and other "corrupters of language" arose. This essay will show how Kraus wrestled with his own Jewish identity through his use and interpretation of language in the pages of his works, at the same time succeeding in isolating himself in his own sort of "paper ghetto." 


\section{Chapter II: Fin-de-Siècle Vienna - Anti-Semitism and Jewish Identity}

"Nothing is more narrow minded than chauvinism or race hatred. To me all men are equal: there are jackasses everywhere, and I have the same contempt for all. No petty prejudices!" ${ }^{1}$

\section{Austrian Anti-Semitism}

During the late nineteenth and early twentieth centuries, the percentage of the Jewish population of Vienna compared to other European cities was very high. Over 175,000 Jews were recorded in the census of 1910, not counting those who were konfessionslos or who had converted. ${ }^{2}$ The political and social influence of Jewish groups was enhanced, in perception if not in practice, by the extreme national and cultural diversity present in the late Habsburg Monarchy. A large portion of the elite German-speaking Austrians were unable to accept the fact

${ }^{1}$ Karl Kraus, quoted in Harry Zohn, Karl Kraus (New York: Twayne Publishers, 1971), 59.

${ }^{2}$ Vienna's share was not the largest, however. Fifty percent of the population of Cracow was Jewish, twenty-five percent in Lemberg and Budapešt, and around 10 percent in Prague. Vienna's Jewish population was at least double that of Berlin and Hamburg, with four to five percent and two to three percent, respectively. Brigitte Hamann, Hitler's Vienna: A Dictator's Apprenticeship, translated by Thomas Thornton (Oxford: Oxford University Press, 1999), 326-327; Frank Field, The Last Days of Mankind: Karl Kraus and his Vienna (New York: St. Martin's Press, 1967), 60. 
that what they considered to be a unitary empire was being transformed into a modern federalist nation-state in response to the demands of nationalism and individualistic cultural identity. ${ }^{3}$ In this atmosphere, Jewish aspirations, either towards assimilation or Zionist nationalism, were heavily influenced by anti-Jewish sentiment and action. Out of the 6,999 Jews recorded in the Lower Austrian census of 1857, 6,217 lived in Vienna where they formed 2.17 percent of the population. ${ }^{4}$ Between 1857 and 1910, Vienna's Jewish population increased dramatically. The following table illustrates this trend. ${ }^{5}$

${ }^{3}$ John W. Mason, The Dissolution of the Austro-Hungarian Empire, 1867-1918, $2^{\text {nd }} \mathrm{ed}$. (London and New York: Longman, 1997), $32-45$.

${ }^{4}$ The number of Jews in the Habsburg Empire around the middle of the nineteenth century has been estimated at eight hundred thousand. In the same period, about three hundred thousand Jews lived in the German Confederation compared with over two million in the Russian Empire. Jonathan Frankel, The Damascus Affair: "Ritual Murder," Politics, and the Jews in 1840 (Cambridge University Press, 1997), 6.

${ }^{5}$ It should be noted that the census recorded persons as Jewish based on their religion, and therefore does not include individuals who renounced their religion or had left the Jewish community. 


\begin{tabular}{|c|c|c|c|}
\hline Year & Jewish Population & $\begin{array}{c}\text { Percent of } \\
\text { Viennese } \\
\text { Population }\end{array}$ & $\begin{array}{c}\text { Populati } \\
\text { on of } \\
\text { Vienna }\end{array}$ \\
\hline 1857 & 6,217 & $2.17 \%$ & N/A \\
\hline 1880 & 72,588 & $10.29 \%$ & 704,756 \\
\hline $1890 *$ & 118,495 & $8.68 \%$ & $1,364,548$ \\
\hline 1900 & 146,926 & $8.77 \%$ & $1,674,958$ \\
\hline $1910^{6}$ & 175,294 & $8.7 \%$ & N/A \\
\hline
\end{tabular}

*The incorporation of new suburbs reduced the proportion of Jews to the rest of the population. Source: Jakob Thon, Die Juden in Österreich, (Berlin: Halensee, 1908), $15-16$.

Although the percentage of Jews in Vienna was highest in 1880, mass Jewish immigration to the city slowed in the first decades of the twentieth century until a sudden influx of Galician and Hungarian Jews in 1923 due to the chaotic political events that followed the dissolution of the Austro-Hungarian Empire.

This rapid growth was due mostly to heavy immigration of poverty-stricken Jews from central and eastern Europe. Notwithstanding their relatively low numbers, the Viennese Jews were a highly visible minority. According to Menachem Rosensaft, Jewish intellectuals soon gained control of the liberal press, and within a short time became "so identified with the [Liberal] party that its opponents were able to use anti-Semitism as a highly effective weapon

${ }^{6}$ Figures for 1910 are from Field, The Last Days of Mankind, 60 . 
against the liberals." ${ }^{7}$ Interestingly, despite the successes of the Liberal Party in Vienna during the late nineteenth-century, no Jews were elected or appointed to office in the city because "the Liberals were widely regarded as the party of the wealthy Jews." ${ }^{8}$ In fact, it was not until after the anti-Semitic Karl Lueger was mayor that Julius Porzer, of Jewish heritage, became deputy mayor in $1904 .^{9}$

The conservative and nationalist elements of Viennese society saw the massive immigration of Ostjuden, or eastern European Jews, as a threat. These conservatives responded by attempting to limit Jewish immigration from the east and resorted to anti-Semitic stereotypes and generalizations to support their anti-Jewish stance. Kraus was surrounded by an atmosphere of hostility and thus felt that a response

\footnotetext{
${ }^{7}$ Menachem Rosensaft, "Jews and Antisemites in Austria at the End of the Nineteenth Century," in Leo Baeck Institute Year Book, 21 (1976), ed. Arnold Paucker, (London: Martin Secker and Warburg, 1982), 58. It should be noted that although the major Viennese newspapers were operated by Jews, they did not become "Jewish" publications or forums for Jewish issues. In fact, quite the opposite was true. The Neue Freie Presse's policy towards antiSemitism was to ignore it and hope that it would "disappear" rather than bring the Jews and Jewish issues to the attention of the Neue Freie Presse's readership.

${ }^{8}$ Field, The Last Days of Mankind, 63.

${ }^{9}$ Ibid.
} 
was necessary. Rather than opt for zionism or blame the Eastern Jews for anti-Semitism, Kraus chose to represent the "liberal Jew" as the real cause of anti-Semitism and to champion a move towards complete assimilation and the rejection of "Jewish" Iinguistic characteristics.

\section{Judaism and the Liberal Movement}

- A Target for Attack

Jews in the Habsburg Empire were not granted full emancipation until 1867, after a period of limited constitutional government. ${ }^{10}$ The Jews owed their newly liberated status to the strength of the liberal movement during the middle of the nineteenth century. It was also during this period that the perception of the Habsburg Empire as a great power began to come into doubt. They

${ }^{10}$ Robert Kann, "German-Speaking Jewry During AustriaHungary's Constitutional Era (1867-1918) Jewish Social Studies 3 (July 1948) : 239. The Jews of the Habsburg Empire were first granted emancipation from the ghettoes under Josef II's Edict of Toleration in 1782. Theobald, The Paper Ghetto, 18. However, it was only after the revolution of 1848 that marriage and religious restrictions were removed. The last obstacles to free economic activity were not surmounted until 1859, and full emancipation was only granted after the creation of the Dual Monarchy in 1867. Hillel J. Kieval, "The Social Vision of Bohemian Jews: Intellectuals and Community in the 1840s, "in Frankel and Zipperstein, eds., Assimilation and Community: The Jews in nineteenth-century Europe (Cambridge: Cambridge University Press, 1992), 246. 
suffered a military defeat at the hands of the French in 1859 and the Prussians in 1866, and were forced to sign an Ausgleich (Compromise) with Hungary that gave the Hungarian Magyars some measure of autonomy. ${ }^{11}$ Although outside appearances were strengthened through an alliance with the newly formed German Reich in 1879, the Habsburg Empire contained a fragmented, multi-national population, of which the Jews were only one minority, and faced many internal difficulties. Austrian liberalism during this period was supported only by the upper middle class and was often associated with the Jews. ${ }^{12}$ Liberalism was never able to cultivate support from the masses, either in rural areas or in the cities. Thus, it often came under attack from other parties, such as the Christian-Socialists and the PanGermans who adhered to radically different viewpoints. ${ }^{13}$ As

${ }^{11}$ Mason, The Dissolution of the Austro-Hungarian Empire, 5-6.

${ }^{12}$ Marsha L. Rozenbilt, The Jews of Vienna, 1867-1914 (Albany: State University of New York Press, 1983), 6, 34, 154-155; Bruce F. Pauley, From Prejudice to Persecution: A History of Austrian Anti-Semitism (Chapel Hill: University of North Carolina Press, 1992), 43-44; Robert S. Wistrich, The Jews of Vienna in the Age of Franz Joseph (Oxford: Oxford University Press, 1989), 140-153.

${ }^{13}$ Robert A. Kann, A History of the Habsburg Empire, 1526-1918 (Berkeley: University of California Press, 1974), 430-443. 
the biggest beneficiaries of liberalism, Jews were strong supporters of the liberal cause. ${ }^{14}$ Such associations led to the successful use of anti-Semitic and racist propaganda by conservatives against the Liberal Party.

Right-wing groups such as the Christian Socialists, under the leadership of Karl Lueger, and the Pan-German and nationalist groups, particularly the new Deutschnationale Verein led by Georg von Schönerer, were able to undermine the progressive measures implemented by the Liberal Party during the last decades of the nineteenth century. This was accomplished by appealing to the racial stereotypes and prejudices of large segments of the population. These proGerman right-wing political parties exerted control through key economic positions in Austria. Although more liberal pro-German figures dominated the major newspapers, including the Neue Freie Presse, after 1888 the socialist Arbeiter zeitung, and after 1894, the clerical Reichspost, the fanatical nationalist groups were able to promote their ideas through small publications and propaganda pieces. ${ }^{15}$ Since the radical and racial elements of German nationalism

${ }^{14}$ Wistrich, The Jews of Vienna in the Age of Franz Joseph, 140-153 ; Kann, "German-Speaking Jewry During Austria-Hungary's Constitutional Era," 242.

${ }^{15} \mathrm{Kann}$, A History of the Habsburg Empire, 432. 
were not directly connected to major newspapers, their influence was focused instead on a "series of rapidly appearing and disappearing dailies and periodicals."16

The powers of the press were also labeled as "Jewish." According to Peter Pulzer, Jews dominated journalism more than any other profession.

Most of the leading organs of opinion, the National-Zeitung of Berlin, the Frankfurter Zeitung, the Neue Freie Presse in Vienna, were owned and edited by Jews... In the humorous papers, UIk, Kladderdatsch, and Berliner-Wespe, Jews had a monopoly on political satire. It can be said that only in the specifically clerical or conservative press were no Jews found. The "Liberal" press, which grew up with industry and parliamentarism and flourished by advertising and sensational reporting, owed its origins almost entirely to Jews. ${ }^{17}$

In Kraus's view, journalists had no responsibility to the true representation of news, they simply were after a story that would sell newspapers for economic gain. The exploits of the press were unconscionable. Journalists often printed advertisements disguised as news articles. The founder of the Neue Freie Presse once stated that his ideal for a newspaper would be one "that did not contain a single

${ }^{16} \mathrm{Ibid}$.

${ }^{17}$ P.G.J. Pulzer, The Rise of Political Anti-Semitism (New York, London: John Wiley and Sons, 1964), 13. 
line which had not been paid for."18 Economic speculation and manipulation also abounded, particularly focused on the upper bourgeoisie. The Neue Freie Presse's "Economist" section dictated the financial market of the empire. Thus, the Liberals were blamed for the series of economic depressions that plagued Austria and Germany during this period. The focal point of this criticism of the Liberals was then placed on the Jews. The burgeoning capitalist system was blamed for causing the economic disasters, and Jews were caricatured as the money-lenders and usurpers. The conservative parties competed to reduce the political freedoms enjoyed by Jews and hoped to weaken the Liberal Party in the process. They also attempted to limit the immigration of eastern Jews, ${ }^{19}$ organized boycotts of Jewish shops, and effectively blocked entry of Jews into

${ }^{18}$ Edward Timms, Karl Kraus, Apocalyptic Satirist: Culture and Catastrophe in Habsburg Vienna (New Haven: Yale University Press, 1986), 32.

${ }^{19}$ Due to the new freedoms gained by Jews during the liberal period in Austrian history, large numbers of Jews from the poor eastern provinces of the empire immigrated into Vienna. These Jews wore traditional Jewish clothing, spoke primarily Yiddish or simple German, and were easily differentiated from other Viennese citizens. They were thus easy targets for anti-semites and violence. Steven E. Aschheim, Brothers and Strangers: The East German Jew in German and German Jewish Consciousness, 1800-1923 (Madison: University of Wisconsin Press, 1982), 3-79. 
positions within the universities. ${ }^{20}$ All of these factors came to a climax between 1897 and 1898. During this period, the Austrian Empress Elisabeth (wife of the philosemitic Francis Joseph) was assassinated by Lucheni, an Italian anarchist; the Dreyfus Affair was causing upheaval in Paris; and Theodor Herzl founded political Zionism in Vienna. ${ }^{21}$ Looking back at this period during the final years of his life, Karl Kraus saw realized that the "golden era" of Vienna was over. He referred to this time as a "paradise 1ost." 22

\section{Jewish Identity and Anti-Semitism}

It is easy to understand why a significant number of Jews thought they could escape anti-Semitism and prejudice through conversion, which they viewed as a means to

${ }^{20}$ Kann, "German-Speaking Jewry During Austria-Hungary's Constitutional Era," 248.

${ }^{21}$ Timms, Karl Kraus, Apocalyptic Satirist, 35. The aging emperor Francis Joseph, after receiving the news of his wife's murder, was heard to say "So I will be spared nothing in this world?" - an eerie prediction of the decades to come. E.C. Corti and H. Sokol, Der alte Kaiser: Franz Joseph I. vom Berliner Kongress bis zu seinem Tode Styria, Graz, 1955), 234; quoted in steven Beller, Francis Joseph (London and New York: Longman, 1996), 157.

${ }^{22}$ Karl Kraus, Die Fackel (München: Kösel-Verlag, 19681973), nos. 912-915, p. 9. 
accelerate the process of assimilation. This is precisely what many Viennese Jews chose to do as a way of distancing themselves from the "Jewish Question." Viennese Jews converted to Christianity at a higher rate than anywhere else in Europe. ${ }^{23}$ Many "westernized" Jews believed themselves to have assimilated into western society, even though they were still often seen as Jews, both by antiSemites and by Jews themselves. At the same time, the Zionist movement was encouraging Jewish nationalism, and this in turn directly contradicted the assimilationist trend of most German-speaking Jewry. ${ }^{24}$ However, the sudden flood of eastern immigrants from impoverished areas of eastern Europe also aroused a profound fear in the hearts of westernized, acculturated Jews who were trying to distance themselves from Judaism. ${ }^{25}$

${ }^{23}$ Rozenbilt, The Jews of Vienna, 7, 128, 132 ; Pauley, From Prejudice to Persecution, 58.

${ }^{24}$ To encourage assimilation, the German-Jewish community favored a "Reform Judaism that separated religious identity from ethnicity and that regarded German Jews as 'Germans of Mosaic faith'." Aviel Roshwald, "Jewish Cultural Identity in Eastern and Central Europe during the Great War" in Aviel Roshwald and Richard stites, eds. European Culture in the Great War: The Arts, Entertainment, and Propaganda, 1914-1918 (Cambridge: Cambridge University Press, 1999), 105. 
Until the revolution of 1848 , Jews were not legally allowed to settle in Vienna or to establish an organized community there. However, some wealthy Jews were "tolerated," so that there were almost 4,000 Jewish residents in Vienna by 1848. After the full emancipation of the Jews in 1867, Jews from all areas began to emigrate to Vienna. A large population of Ostjuden (eastern Jews), primarily from the eastern European province of Galicia, settled in and around the Jewish suburb of Leopoldstadt. ${ }^{26}$ The historical memory of the "ghetto Jew" was still prevalent in Austrian society, and the ostjuden were highly evocative of this image. Whereas acculturated, westernized Jews looked like non-Jewish Germans and could blend into a non-Jewish society, the Ostjuden were a continual reminder

${ }^{25}$ Marsha L. Rozenbilt, "Jewish Assimilation in Habsburg Vienna," in Johnathan Frankel and Steven J. Zipperstein, eds., Assimilation and Community, 226.

${ }^{26}$ The first Jews were brought into Vienna around 1150 and worked as moneylenders and tradesmen under special monarchial protection. Vienna had its first synagogue by 1200. Emperor Leopold I, at the behest of his Spanish wife Margarita Theresa, had all Viennese Jews expelled in 1670. The synagogue was burned, and a Catholic Church built in its place. The old ghetto inhabited by the Jews, Leopoldstadt, existed as a Catholic suburb. A few years later, the now-widowed emperor was in need of money and the Jews were brought back into Vienna and placed in Leopoldstadt, which was scornfully referred to as "Matzohville." By 1900, nearly one-third of all Jews in Vienna lived there. Hamann, Hitler's Vienna, 325-326. 
of the stereotypical "Jewish" vagabond. Generally, in what could be termed non-rational or "stereotypical" antiSemitism, the east European Jews were seen as "dirty, loud, and coarse...immoral, culturally-backward creatures of ugly and anachronistic ghettoes" by both acculturated Jews and non-Jews. ${ }^{27}$ As these Jews became an increasingly common sight in Vienna, the acculturated Jews made a concerted effort to distance themselves from "Jewish" associations. In this ocular regime, Jews who were discernable "by sight," such as the Ostjuden, were easy and likely targets for anti-Semitism. Their very presence served as a catalyst for anti-Semitism directed toward themselves and more acculturated Jews. The close association of antiSemitic stereotypes of the "eastern Jew" could easily be transferred to all persons regarded as "Jewish."28

One of the peculiarities of Austrian and German societies during the nineteenth and early twentieth centuries was the rather confusing issue of "who was

${ }^{27}$ Aschheim, Brothers and Strangers, 3.

${ }^{28}$ Steven Aschheim's discussion of German sentiment with regard to the eastern Jews can also be extended to Vienna during this time. Despite having their own empire, the Habsburgs were uniquely connected to German culture and language. Steven E. Aschheim, Brothers and Strangers, 154156 ; also Roshwald, "Jewish Cultural Identity in Eastern and Central Europe during the Great War," 105-107. 
Jewish?". During this particular phase of Austro-German history, Jews were labeled as an "ethnic group," both by Jews and non-Jews. ${ }^{29}$ Thus, simple conversion was insufficient to make someone "un-Jewish." People of Jewish descent were considered Jewish, regardless of their professed religion, and the actual acceptance of someone as non-Jewish was never clarified. Anti-Semitism abounded throughout Austria, but it was never as clearly raciallyoriented as the German National Socialist version. Steven Beller claims that this was the case simply because, "like all things Viennese, no one had bothered to clarify it." ${ }^{30}$ According to Arthur Schnitzler, "it was impossible,

${ }^{29}$ According to Austrian law, all Jews were required to belong to the Israelitische Kultusgemeinde (organized Jewish Community of Vienna) unless they declared themselves konfessionslos and left the Jewish fold. Rozenbilt, The Jews of Vienna, 1867-1914, 11. Bruce Pauley has argued that "most Jews, even in Western Europe would have agreed as late as the mid-nineteenth century that they were a separate nation," since they were still not granted full freedoms under the law. By 1914, however, acculturated Jews "considered themselves to be members of the surrounding gentile nationality." However, the assertions of anti-Semites and the close associations of Western Jews primarily with other acculturated Jews forced all persons of Jewish background to maintain a Jewish identity on some level, even if they considered themselves to have assimilated into German culture. Pauley, From Prejudice to Persecution, 57.

${ }^{30}$ Steven Beller, Vienna and the Jews, 1867-1938 (Cambridge: Cambridge University Press, 1989), 205. 
especially for the Jew in the public eye, to ignore the fact that he was a Jew, for the others did not, the Christians not, and the Jews even less" (Es war nicht möglich, insbesondere für einen Juden, der in der Öffentlichkeit stand, davon abzusehen, dass er Jude war, da die andern es nicht taten, die Christen nicht und die Juden noch weniger). ${ }^{31}$

\section{Karl Kraus and Jewish Identity}

In the midst of this hostile environment devoid of clear distinctions of "identity" and "community," a young Kraus entered the Franz-Josephs-Gymnasium in 1884. Also attending the school at the same time was Hugo Bettauer, who later wrote Die stadt ohne Juden, a fictional story of the expulsion of the Jews from Vienna in the 1920 s that described how culture and prosperity in Vienna disappeared

${ }^{31}$ Arthur Schnitzler, Jugend in Wien (Frankfurt am Main, 1981), 322 ; quoted in Beller, Vienna and the Jews, 18671938, 205-206. Schnitzler's novel Der Weg ins Freie revolves around young acculturated Viennese Jews who were attempting to assimilate into society while the paths of liberalism previously open to them were being swept away. Arthur Schnitzler, Der Weg ins Freie (Berlin: S. Fischer, 1920); Carl E. Schorske, Fin-de-Siècle Vienna: Politics and Culture (New York: Vintage Books, 1981), 12. 
without the presence of a Jewish element in society. ${ }^{32}$ Bettauer's views of such an expulsion of Viennese Jewry provide a counterpoint to Kraus's later views of Jewish assimilation as the answer to anti-semitism. The ideas of both authors were clearly linked to their exposure to antiSemitism and the responses of Jews and non-Jews to the "Jewish Question" in Vienna during this time.

For some German-speaking Jews who were reared in a thoroughly assimilated fashion, anti-Semitism was not always perceived as an immediate threat to themselves, but rather as directed at the Jewish community as a whole. In most cases, these individuals became aware of the inherent problems of being both German and Jewish. These GermanJews often came to be torn between the western culture in which they wished to participate and their Jewish heritage, which they had left behind. In addition to Kraus, other

${ }^{32}$ Hugo Bettauer, Die Stadt ohne Juden: ein Roman von Übermorgen, (Frankfurt am Main: Ullstein, 1988). Bettauer was also the victim of the first Nazi-organized murder in Austria. He was shot at point-blank range by Otto Rothstock on March 10, 1925. In addition to his novel, Bettauer was also known as the "father of the sexual revolution in Vienna." See Yale Companion to Jewish Writing and Thought in German Culture, 1096-1996. Sander I. Gilman and Jack Zipes, eds. (New Haven: Yale University Press, 1997), 440 . 
Jews were forced to develop different solutions for solving the Jewish "problem."

Jakob Wassermann (1873-1934), in his autobiography My Way as a German and a Jew, explained that he could identify with Germans and Germany from a young age. His blond hair and generally "non-Jewish" appearance aided him in assimilating with non-Jewish Germans and allowed the young Wassermann to consider himself "German" by nationality. However, in a culture that rejected his works as profoundly "un-German," Wassermann became isolated and marginalized. Like Kraus, Wassermann was unable to find comfort or support in Zionism because of his close identification with German culture. Thus Wassermann declared:

I found myself rejected and isolated in a triply difficult position; as a man of letters, as a German without social standing, as a Jew detached from my group. ${ }^{33}$

Gustav Mahler is another example of a German-speaking Jew who felt the pressure of isolation and marginalization despite his conversion to Christianity. By attaining one of the most prestigious posts of the Viennese cultural world, Director of the Court Opera, Mahler had proven that Jews

${ }^{33}$ Jakob Wassermann, My Way as a German and a Jew (New York: Coward-McCann, 1933), 125. 
could assimilate and be successful in Austrian society by renouncing Judaism and adopting German culture. Mahler had become Catholic in 1897, and married into an elite Austrian family. Like Wassermann, Mahler imagined himself as triply isolated from the society in which he lived:

Ich bin dreifach heimatlos: als Böhme unter den österreichern, als Österreicher unter den Deutschen und als Jude in der ganzen Welt. Überall bin ich Eindringling, nirgends "erwünscht. " 34

I am thrice homeless, as a Bohemian among Austrians, as an Austrian among Germans, and as a Jew throughout the world. Everywhere I am regarded as an interloper, nowhere am I what people call "desirable."

Kraus, like Mahler, was Bohemian, Austrian, and Jewish, and felt the same sort of loss and displacement. Despite distancing themselves from Judaism, Wassermann, Mahler, and Kraus were still ostracized and isolated from the culture in which they were reared. Despite Kraus's claims and support for complete assimilation, the accomplishment of such a goal proved to be elusive.

Rather than renounce his claims to Judaism, Wassermann maintained his dualistic identity for the rest of his life, later writing, "I refuse to deny myself, I refuse to betray 
myself." ${ }^{35}$ Reared within an assimilated framework, Wassermann believed himself to be both German and Jewish, and the majority of his works attempted to reconcile this view. Fürth, the German Jewish community in which Wassermann was born, dated back to the ninth century. His family ties stretched back four centuries. Thus, Wassermann believed himself to be a true German through "an innate tie of blood to the German landscape and an unshakable claim to a German identity." ${ }^{36}$

Despite this identification with Germany, Wassermann paradoxically maintained that Jews remained distinct and "Oriental" by virtue of blood. Wassermann claimed however, that such "Oriental" characteristics should not be used to restrict the rights or freedoms of Jews in Germany. For Wassermann, Jews and non-Jews could learn to live in harmony in Germany, united in a German identity.

Wassermann's idea of harmony is in direct contrast to Kraus's perception of the situation of the Jews. After the

${ }^{34}$ Steven Beller, Vienna and the Jews, 207 ; Helmut Gruber, "Red Vienna and the "Jewish Question"," in Leo Baeck Institute Year Book XXXVIII (1993) : 105.

${ }^{35}$ Wassermann, My Way as a German and a Jew, 263.

${ }^{36}$ Marcus Bullock, Yale Companion to Jewish Writing and Thought in German Culture, edited by Gilman and Zipes, 474 . 
Dreyfus Affair, Kraus rejected Judaism in 1899, declaring himself konfessionslos at the age of twenty-five. ${ }^{37} \mathrm{He}$ firmly believed that the only way to end anti-semitism was complete assimilation on the part of the Jews, thereby eliminating the target of attack. Much as Zionism isolated the Jews as a "national" group and therefore a target for anti-Semitism, Wassermann's idealistic view of a GermanJewish utopia only served to perpetuate the identities of "Jew" and "German" as distinct and therefore in competition. Wassermann's worldview was also bound by the blinders of nationalism. He saw no underlying bond with Polish or Galician Jews, as a social group, but rather placed the defining factors on individualism and national identity.

Kraus, on the other hand, saw language, rather than nationalism, as the most significant characteristic that divided societies. Kraus acknowledged the plight of the Galician Jews, but he believed that through education, the proper use of German and the rejection of their Jewish identity, the ostjuden would gradually cease to be a target of anti-Semitism and become assimilated. For Kraus, the only true solution to the "Jewish question" for Jews living

${ }^{37}$ Zohn, Karl Kraus, 17. 
in or emigrating to the West was complete assimilation into western society and the complete rejection of everything Jewish.

\section{Kraus's Early Works-}

\section{Anti-Establishment, Anti-zionist}

Between 1894 and 1896, Kraus contributed several pieces to the Neue Freie Presse. Kraus's first pamphlets, Die demolirte Literatur (1896) and Eine Krone für zion (1898), became the intellectual foundations for his satire. With these works, Kraus effectively isolated himself from the two leading social movements that were popular among the bourgeois intellectuals of the day: the culturalliterary "Jung Wien" and Theodor Herzl's radical answer to the "Jewish Question," Zionism."

${ }^{38}$ After publishing Eine Krone für Zion, Kraus was offered a position as a satirical writer for the Neue Freie Presse in January 1899. The position had been vacant since the death of Daniel spitzer, whom Kraus greatly admired, in 1893. Spitzer's witty and satirical "Wiener Spaziergänge" ("Viennese Perambulations") column was widely read in Vienna during this period. Although Kraus had aspired to the position earlier, he declined the offer and instead began production and publication of his own journal, Die Fackel. Kraus would later say that "there are two fine things in the world: to be a part of the Neue Freie Presse or to despise it. I did not hesitate for one moment as to what my choice had to be." Kraus, Die Fackel, no. 5, 11. Also, Harry Zohn, Karl Kraus, 15-18, 34-36. 
Die demolirte Literatur, Kraus's first major

satirical work, appeared in the Wiener Rundschau in 1896.

This work attacked the frivolity of the Jung wien group of coffeehouse literati, of whom Kraus had been generally

associated. The key targets of Kraus's venom were Hermann Bahr and Felix Salten, the former a key member of the Jung Wien, and the latter the foremost feuilleton writer at the time. ${ }^{39}$ Salten was so offended by Kraus's lightly concealed attack on him that he physically attacked Kraus in public and gave him a beating. Kraus, never the forgiving type, continued to lampoon and belittle salten at every opportunity. ${ }^{40}$

Kraus's second work, Eine Krone für Zion (1898), attacked Zionism as a misguided and inherently flawed reaction to anti-Semitism. It is important to note that

${ }^{39}$ Salten is most famous as the author of the famous children's story Bambi and, interestingly enough, as the anonymous author of a pornographic novel, Josefine Mutzenbacher: Die Lebensgeschichte einer wienerischen Dirne (Josefine Mutzenbacher: The Story of a Viennese whore). Harold B. Segel, The Viennese Coffeehouse Wits, 1890-1938 (West Lafayette: Purdue University Press, 1993), 166. Ritchie Robertson, The "Jewish Question" in German Literature, 1749-1939 (Oxford: Oxford University Press, 1999), 313 .

${ }^{40}$ Kraus wrote a parody of salten's sequel to Bambi, the story Fünfzehn Hasen (Fifteen Rabbits), in which Kraus pointed out the "Jewish" mannerisms of the rabbits. Segel, The Viennese Coffeehouse Wits, 61, 166-67. 
the zionist movement emerged at this time only after the Jews were freed from the ghettoes and began to become integrated into modern culture. Under increasingly hostile pressure from social and political groups in late nineteenth-century Vienna, a replacement for the protection offered by the physical walls of the ghettoes became necessary for psychological reasons. While some Jews chose to embrace liberalism or helped to shape Viennese culture through artfully written newspaper pieces, others concluded that assimilation into the ardently nationalist and often anti-Semitic Austrian society was impossible. Theodor Herzl's response to the fanatical nationalism of Vienna was to create a Jewish nationalist movement, Zionism, to provide a refuge for Jews who could not assimilate into Western society.

The first Zionist Congress was held in Basel, Switzerland in August 1897. In Herzl's mind, Zionism sought to provide a "publicly recognized, legally secured home in Palestine" for the Jewish people. ${ }^{41}$ Zionism was unique among all other forms of nineteenth century nationalism in that its goals were to acquire political

${ }^{41}$ Arthur Hertzberg, ed. The zionist Idea: $A$ Historical Analysis and Reader (New York: Atheneum, 1959, 203. 
sovereignty without the usual preexisting conditions of a common language or national state for the people it intended to represent. Zionism envisioned the creation of a Jewish nation and a Jewish national language and thereby a Jewish national identity simply through "the élan of its nationalist will."42 Herzl's idea also broke with the previous notions for resolving the Jewish Question in that it did not see either assimilation or religious reforms as successful solutions for the Jewish people. ${ }^{43}$

Herzl's belief that the western nations, however liberal and progressive, would never fully accept Jews as complete members of their societies arose out of his perception of the anti-Semitic sentiments of Austria and from his personal experiences in Paris as a correspondent for the Neue Freie Presse where he reported on the Dreyfus Affair. Zionism would create a Jewish nation, outside of Europe, as a "Jewish sacrifice" for the creation of the modern world. According to Arthur Hertzberg, Herzl's great faith in liberalism allowed "the Jew to assure the peace of western society by abandoning it for a state of his [the

${ }^{42}$ Ibid, 15.

${ }^{43}$ Ibid, 20-21. 
Jew's] own, [as] it is the ultimate sacrifice on the altar of his love for the modern world." ${ }^{44}$

For Herzl and many other zionists, anti-Semitism was a necessary force. It was needed to motivate the Jews towards the creation of their own national identity. Political Zionism explained hatred of the Jews as a "mixture of national antipathy and economic struggle" which made anti-Semitism "the engine driving the train towards Zion." ${ }^{45}$ However, Herzl and others had a profound faith in nineteenth century liberalism and sincerely believed that this liberalism would prevent anti-Semitism from seriously injuring the Jewish people. For Herzl, the "Jewish Question" was a dialectical problem. Anti-Semitism was the thesis, with liberalism and nationalism as its antitheses. Since he possessed an extraordinary faith in the continual forward motion of progress and emancipation for Jews, Herzl conceived of Zionism as the synthesis of these two conflicting ideologies of the nineteenth century. ${ }^{46}$

In direct contrast to Herzl's view, Kraus saw Zionism as picking up where anti-Semitism left off. Rather
${ }^{44}$ Ibid, 54 .
${ }^{45}$ Ibid, 51.
${ }^{46}$ Ibid, 50. 
than attempting to force Jews back into their old ghettoes, Zionists encouraged Jews into a "new ghetto" by stimulating anti-Semitic sentiments which would otherwise be overlooked.

Sieht man jedoch von allen Möglichkeiten einer politischen Gefahr ab, dann hat noch immer der gute Geschmack ein Recht, dagegen zu protestiren, dass die Gedankenfülle, aus der der betrunkene Greisler in Hernals sein "Hinaus mit Euch, Juden!" ruft, im Zionismus ihre einfache Wiederholung erfährt, und dass die Antwort "Jawohl, hinaus mit uns Juden!" bis auf den feierlicheren Ton gar zu wenig Abwechslung bietet.... ${ }^{47}$

While refraining from every possibility of political danger, good taste still has a right to protest when the intellectual wealth from which the drunken old man in Hernals shouts his 'out with you, Jews!' meets with simple repetition by Zionists, and that their answer 'Yes, out with us Jews!' offers too little variety save in its celebratory tone....

Zionism discouraged assimilation at the very time that such assimilation was achieving its first successes with westernized, educated Jews. It called for the poorer Jews of eastern and central Europe to emulate their western brothers so that the Jewish people could unite as one nation in Palestine. Kraus felt that Zionism simply made Jews, eastern Jews in particular, the focal point of an 
even more dangerous form of anti-Semitism, pitting

nationalist against nationalist. Rather than exporting the problems of the Jews to another area, the situation of the Jews in Europe should be improved.

${ }^{47}$ Karl Kraus, "Eine Krone für Zion," in Frühe Schriften, vol. 2 (Munich: Kösel Verlag, 1979), 312. 


\title{
Chapter III: Karl Kraus and the "Jewish Question"
}

\author{
"Keep your passions in check, but beware of giving your \\ reason free rein." ${ }^{1}$ \\ "To be human is erroneous." 2
}

\section{Jewish Responses to the "Jewish Question"}

Whereas Zionism called for Jews to celebrate their Jewish identity, many Jews attempted to blend into the dominant Austro-German culture with as little disturbance as possible. Individual Jews or those from wealthy and influential families were largely successful in this endeavor from 1867 until the late 1890s, when widespread political anti-Semitism became prevalent and the non-Jewish bourgeoisie moved away from the Liberal Party and instead supported the Christian Socialists. The newspapers and media of the time, both liberal and conservative, played upon Jewish stereotypes and reinforced the cultural stigmas of what it meant to be a "Jew" in Austria or Germany. This prompted Karl Kraus to declare:

Man weiß, daß mein Haß gegen die jüdische Presse nur noch von meinem Haß gegen die antisemitische übertroffen wird, während hingegen mein Haß gegen

${ }^{1}$ Karl Kraus, Half-Truths and one and a Half Truths: Karl Kraus, Selected Aphorisms, edited and translated by Harry Zohn (Montreal: Engendra Press, 1976), 124.

${ }^{2}$ Ibid. 
die antisemitische Presse nur wieder von meinem Haß gegen die jüdische Presse übertroffen wird...3

One knows that my hatred of the Jewish press is only surpassed by my hatred of the anti-Semitic press, while on the other hand my hatred of the anti-semitic press is only surpassed again by my hatred of the Jewish press...

With this statement, Kraus reveals his obsessive drive to attack all elements that he saw as fostering anti-Semitism and heightening the malicious tension surrounding the "Jewish Question."

Kraus's attacks on his opponents produced a profound negativity regarding the quasi-assimilation of Viennese Jews. Kraus's aim was to end anti-Semitism through complete assimilation, not surrender to it like the Jewish nationalists and the Zionists. Kraus described Theodor Herzl as an executor of the ultimate wishes of the Christian Socialists, who wanted to rid Austria of the Jews anyway. ${ }^{4}$ Assimilation was the only realistic way to resolve

${ }^{3}$ John Theobald, The Paper Ghetto: Karl Kraus and Anti-Semitism (Frankfurt am Main: Peter Lang, GmbH, 1996), 11 .

${ }^{4}$ Karl Kraus, "Eine Krone für Zion, " in Frühe Schriften, vol. 2 (Munich: Kösel Verlag, 1979), 299-301. The efforts of nationalist or Zionist Jews to be recognized as a national minority in Austria was "strangely consonant with the Christian Social[ist] attempts to re-ghettoize the Jews as a subject nationality." Helmut Gruber, "Red 
the "Jewish Question." An egalitarian system of Social Democracy, as "the last major political theory after liberalism's demise in which Jews could hope to be seen as equals," was the direction in which Jews needed to go, not to the east towards Zion. ${ }^{5}$ According to Kraus, "it is hardly acceptable that the Jews will march into the Promised Land with dry feet; another red sea, Social Democracy, will block their way" (Es ist kaum anzunehmen, dass die Juden diesmal trockenen Fusses in das gelobte Land einziehen; ein anderes rothes Meer, die Socialdemokratie, wird ihnen den Weg dahin versperren). ${ }^{6}$

After the liberal reforms of the late nineteenthcentury, the Austrian Jews found themselves in a relatively progressive system. It is true that anti-Semitism was a factor and that the non-Jewish "Iiberal" bourgeoisie had moved to support the anti-Jewish Christian Socialists, but the Jews did have basic human rights (Menschenrechte) in Austria, which gave them equal civil, political, and

Vienna and the "Jewish Question"," in Leo Baeck Institute Year Book XXXVIII (1993) : 104.

5Steven Beller, Vienna and the Jews, 1867-1938 (Cambridge: Cambridge University Press, 1989), 209.

${ }^{6}$ Kraus, "Eine Krone für Zion, " 314. 
religious freedoms, and the Emperor Franz Joseph was described as relatively philo-semitic. ${ }^{7}$

\section{Karl Lueger and the Christian Socialists}

\section{-The Failure of Viennese Liberalism}

Between 1890 and 1920, the Viennese Christian

Socialist movement began to attract large numbers of disillusioned bourgeois groups who had previously supported the Liberal Party. ${ }^{8}$ According to John Boyer, property owners, teachers, government officials, artisans, merchants, shopkeepers, and a group of anti-Semitic Catholic clerics supported the Christian Socialists under the leadership of Karl Lueger. ${ }^{9}$ The party was based around

${ }^{7}$ Marsha L. Rozenbilt, The Jews of Vienna, 1867-1914 (Albany: State University of New York Press, 1983), 10-11; William M. Johnston, The Austrian Mind: An Intellectual and Social History, 1848-1938 (Berkeley: University of California Press, 1972), 40.

${ }^{8}$ Some factors for this shift were the overall weakness of the Liberal Party in Austria, the great stock Exchange Crash of 1873 (in which both wealthy aristocrats and the Viennese middle class suffered heavily, with most of the blame falling on Jews), the implication of members of the Liberal Cabinet in the financial affairs of the LembergCzernowitz Railroad scandal, and the close association of Jews with the Liberal Party. Robert S. Wistrich, The Jews of Vienna in the Age of Franz Joseph (Oxford: Oxford University Press, 1989), 147-148.

"John W. Boyer, "Karl Lueger and the Viennese Jews," in Leo Baeck Institute Year Book XXVI (1981) : 125. 
a policy of nebulous anti-Semitism, which Lueger carefully manipulated to serve his own ends. ${ }^{10}$ With Lueger as mayor of Vienna from 1897 until his death in 1910, the Christian Socialists succeeded in "destroying the Viennese Liberal presence in the city's political culture." ${ }^{11}$ The demise of the Liberal Party was due in large part to its associations with Jews and "Jewish" manipulation of the economy accusations which were emphasized and turned into a grand propaganda scheme by the Christian Socialists and other anti-Semites. Non-Jewish liberals attempted to separate their party from Jewish stereotypes, but they were largely unsuccessful. For their part, the Jews, particularly middle class Jews, continued to support the Liberal Party

10 "Karl Lueger possessed what was probably the most delicately attuned political sense in Austria." He won the support of rabid anti-Semites, Christian idealists, agnostics, clerics, conservatives, and democrats. Andrew G. Whiteside, The Socialism of Fools: Georg Ritter von Schönerer and Austrian Pan-Germanism (Berkeley, Los Angeles, London: University of California Press, 1975), 146. Lueger's famous remark runs, "I decide who is a Jew" ("Wer ein Jud ist, das bestimme ich"). Robert S. Wistrich, Between Redemption and Perdition: Modern Anti-Semitism and Jewish Identity (London and New York: Routledge, 1990), $48,43-54$.

${ }^{11}$ Boyer, "Karl Lueger and the Viennese Jews," 125 ; Carl E. Schorske, Fin-de-Siècle Vienna: Politics and Culture (New York: Vintage Books, 1981), 4-10. 
even after being abandoned by it. ${ }^{12}$ Thus, men like Karl Lueger and Georg Ritter von Schönerer were able to use anti-Semitism as a club to drive non-Jewish supporters further from the Liberal Party. ${ }^{13}$

Lueger himself did not personally dislike Jews. In fact, he often associated with the wealthy, acculturated Jews that were part of the high culture of Vienna. ${ }^{14}$ His use of a "political" anti-Semitism was largely restricted to public propaganda campaigns aimed at influencing the disenfranchised masses and providing a release for their dissatisfaction with Viennese society in the twilight years of the Habsburg Empire. ${ }^{15}$

${ }^{12}$ The Jewish middle class had little choice. "They could not vote for the anti-semitic Christian socialists or the antibourgeois Social Democrats. Thus the establishment's press urged the Jews of Vienna, and indeed all of Austria, to vote for Liberal candidates in the nalve hope that they might defend Jewish rights in parliament." Rozenbilt, The Jews of Vienna, 180.

${ }^{13} \mathrm{Jacob}$ Toury, "Troubled Beginnings: The Emergence of the Österreichisch-Israelitische Union," in Leo Baeck Institute Year Book XXX (1985) : 458.

${ }^{14}$ Boyer, "Karl Lueger and the Viennese Jews," 126-127; Whiteside, The Socialism of Fools, 146-148.

${ }^{15}$ Although it has been shown that the assimilated Jews of Vienna did not suffer material losses during Lueger's tenure in power, they certainly felt the pressures of bourgeois hostility towards successful Jews, much as the Ostjuden were the targets of the anti-semitic working class. Under the Christian Socialists, Jews were labeled 
The weakness of the Austrian Liberal Party resulted from their "rise" to power in the 1860s, after the Austrians were defeated by the Prussians. They were unable to overthrow the power of the aristocracy and the emperor during the revolution of 1848, and it was only in the economic and social chaos after 1868 that they gained any real power in the Austrian government. Although they did institute liberal reforms for the next two decades, it was only with the acquiescence of the aristocracy and the old imperial bureaucracy. Popular support for the Liberals was limited to the German middle classes in the cities and assimilated Jews. ${ }^{16}$ In the first few years of the twentieth century, the Liberal Party had lost nearly all its political influence due to its disintegration into ever smaller factions. ${ }^{17}$

as "agents of cultural fragmentation and social disunity," and could never be fully admitted into Viennese society. Boyer, "Karl Lueger and the Viennese Jews," 126-127, 132.

${ }^{16}$ Schorske, Fin-de-Siècle Vienna, 5. Additionally, the Austrian bourgeoisie was dependent upon the emperor for political support, having failed to defeat or completely merge with the aristocracy. The aristocracy was mostly Catholic, and therefore unsympathetic to the problems of the liberals and their "Jewish elements".

${ }^{17}$ Toury, "Troubled Beginnings," 458. 


\section{The Jewish Shift Towards Social Democracy}

After 1900, an increasing number of acculturated Jews and intellectuals joined the Social Democratic Party. The founder and leader of the party, Victor Adler, was himself a converted Jew. The party paper, the Arbeiterzeitung, had been edited by Friedrich Austerlitz, a Moravian Jew, since 1895. Austrian workers were well represented by committed Jewish leadership and intellectuals in the social Democratic Party. ${ }^{18}$ Naturally, they faced some anti-Semitic hostility from Lueger's Christian Socialists, but under the leadership of Victor Adler the Social Democratic Party was neutral on the "Jewish Question," claiming that it was "equally opposed to liberal capitalism and anti-Semitism."19 Adler was well aware of the complexities of anti-semitism and was not eager to risk losing the support of the Viennese proletariat. Although the Social Democratic Party was well supported in Vienna, the rural districts of

${ }^{18}$ Robert $S$. Wistrich, Socialism and the Jews: The Dilemmas of Assimilation in Germany and Austria-Hungary (London and Toronto: Associated University Presses, 1982), 332 .

${ }^{19}$ Ibid, 351-352. Even so, this was a stronger stance on these questions than that of the German Social Democrats during the $1890 \mathrm{~s}$. 
Austria were loyal to the Christian Socialists, the PanGerman parties, and other nationalist groups. ${ }^{20}$

The Social Democratic Party was a complex multinational group from the very outset, but by 1908 , it represented the largest national cross-section of Austrian voters. Of the eighty-seven deputies in the Reichsrat in 1908, "fifty were German, twenty-four Czech, six Polish, five Italian, and two Ruthenian."21 Acculturated Jews within the party were tolerated, and even appreciated for their intellectual vigor and commitment to socialist ideas. However, the mass immigration of ostjuden was a continual source of hostility, particularly from the Czechs. The Social Democrats, hoping to avoid the stigma of a "Jewish party," opposed the reforms suggested by the Galician Jews and also the recognition of Yiddish as an official language. ${ }^{22}$ However, tensions between German and Czech nationalism were too difficult for the party leadership to

${ }^{20}$ After the First World War, the Social Democratic Party held majorities in Vienna of 54 to 60 percent, while the other conservative parties held the remainder of the Austrian Republic with at least 57 percent of the vote. Gruber, "Red Vienna and the "Jewish Question"," 101.

${ }^{21}$ Brigitte Hamann, Hitler's Vienna: A Dictator's Apprenticeship, translated by Thomas Thornton (Oxford: oxford University Press, 1999), 317.

${ }^{22}$ Wistrich, Socialism and the Jews, 353. 
resolve. In 1910, a majority of Czech Social Democrats left the party and established the Czech Workers' Party (the Autonomists). Their departure drastically weakened the political unity of the party. ${ }^{23}$

The conservative parties during this time, particularly the Christian Socialists, used anti-Semitism as a weapon not only against the Jews, but against the Social Democrats. More than anywhere else in Europe, the Catholic Church in Vienna played an extremely important political and social role. The Church led the fight against "Red Vienna" and all that was deemed "unChristian." The Christian Socialists' Kulturkampf was motivated by the Church's call to "battle against the Jewish-Socialist anti-Christ." ${ }^{24}$

The Social Democrats reacted to these attacks by turning them upon their opponents. Despite their Jewish leadership, the Social Democrats accused the conservative parties, especially the Christian Socialists, of being "financed by Jewish capitalists, of harboring clandestine

\footnotetext{
${ }^{23}$ Hamann, Hitler's Vienna, 319.

${ }^{24}$ Gruber, "Red Vienna and the 'Jewish Question'," 100.
} 
Jews within its own leadership, and of engaging in 'Jewish practices'." 25

Despite this anti-Semitic rhetoric, the social

Democrats were alone in opposing anti-Semitism in Austria. Over 80 percent of Viennese Jews supported the party, and over 50 percent of party officers were Jews. By comparison, only 10 percent of officers in the Sozialdemokratische Partei Deutschlands (SPD) were Jewish. ${ }^{26}$

It was indeed striking that the only political party willing to take a stand against anti-Semitism still resorted to "Jewish stereotypes" and "Jewish scapegoating" in order to defend itself from criticism. Helmut Gruber assumes that the rationale behind this mentality was based "on the historically mistaken notion that the followers of the opposition, by being made aware of their own party's dependence upon Jewish capitalism, could be persuaded to support the Socialists who fought against capitalism of every stripe." 27 The party chose to suppress their "Jewish element," rather than celebrate the contribution of the Jews to the Social Democratic movement and to the
${ }^{25}$ Ibid.
${ }^{26}$ Ibid, 106.
${ }^{27}$ Ibid, 114. 
intellectual, artistic, and cultural life of Vienna. After a series of revolts in major urban areas between social Democratic forces and government troops in 1934, Chancellor Dollfuss outlawed the Social Democratic Party. The final irony was that the party leaders at that time were blamed, not as over zealous Socialists, but as Jews disrupting the social order. ${ }^{28}$

\section{The "Transparent Ghetto"}

\section{- A Faulty Assimilation}

In order to avoid being seen as "Jewish," and to create his own foundation from which he could work to espouse his own views for solving the Jewish Question, Kraus broke with the two major intellectual groups of Vienna, the Zionists and the literary "Jung Wien" group. This was accomplished through his inflammatory pamphlets, Die demolirte Literatur (1897) and Eine Krone für Zion (1898). Kraus's next move was to leave the Jewish community and become konfessionslos (without religious

${ }^{28}$ For a complete discussion on the history of the Austrian Social Democratic Party, including its "illegal" status after 1934, see Robert Schwartz, "Antisemitism and Socialism in Austria, 1918-1962," in Josef Fraenkel, ed., The Jews of Austria (London: Valentine, Mitchell, \& Co., 1967), 445-466. 
affiliation) in 1899. Kraus considered himself a part of the Jewish community only "through an unpleasant chance of birth" (durch den leidigen Zufall der Geburt), and was eager to prove that he was unwilling to be counted as a member of any group, regardless of its affiliation. ${ }^{29}$

By renouncing Judaism, Kraus had taken the first step toward becoming a full member of German culture. This was an extraordinarily difficult venture given that large segments of the population believed in the pseudo-

${ }^{29}$ Kraus remained konfessionslos until 1911, when "after a time of comfortable and never sufficient nonreligiousness" (nach einer zeit der bequemen und nie genug gewürdigten Konfessionsloskeit), he secretly was baptized and converted to Catholicism. Harry Zohn, "Karl Kraus: "Jüdischer Selbsthasser " oder "Erzjude"?" Modern Austrian Literature 8 (1975) : 1 . He would later publicly renounce his ties to the Catholic Church in 1922 because the Salzburg Cathedral had been made available to Max Reinhardt for a production of Hugo von Hofmannsthal's morality play Jederman as a tourist attraction. Additional factors were the Church's complacent attitude during the First world war and the Catholic Reichpost's assertion that the Jews, the Freemasons, the Social Democrats, and the Czechs were to blame for the war. Initially, Kraus's reasons for such a conversion are unclear (perhaps motivated by the general revival of Christianity before the war), but there is evidence that people only became aware of his conversion when he renounced the Catholic Church in 1922. Frank Field, The Last Days of Mankind: Karl Kraus and his Vienna (New York: St. Martin's Press, 1967), 124 ; Harry Zohn, Karl Kraus (New York: Twayne Publishers, 1971), 2122 . 
scientific mentality of Jewish "racial inferiority." ${ }^{30}$ For Kraus, the idea of complete assimilation became the very model for solving the "Jewish Question." Kraus sought not only to free the Jews from their ghettoes in the east, but also from the "transparent ghetto" of western Jewish assimilation, which only perpetuated the stereotypes and prejudices against the Jews. ${ }^{31}$

These transparent ghettoes were a product of the middle class Jewish bourgeoisie, against whom Kraus and other Jewish intellectuals fought. This view of "transparent ghettoes" is comparable to Herzl's vision of western society in his play, Das neue Ghetto, in which the hero dies while uttering a plea for the Jew to leave the "new ghetto," which anti-Semitism has created. For Herzl, death would be the ultimate result if the Jews continued towards assimilation, which he saw as impossible because

${ }^{30}$ There is an extensive secondary literature on this subject. Some notable examples are: Beller, Vienna and the Jews, 1867-1938, 190-194; Pauley, From Prejudice to Persecution, 27-44; Jack Wertheimer, Unwelcome Strangers: East European Jews in Imperial Germany (Oxford: Oxford University Press, 1987), 77-88, 143-161; Robert S. Wistrich, Between Redemption and Perdition, 31-42; Sander L. Gilman, Jewish Self-Hatred: Anti-Semitism and the Hidden Language of the Jews (Baltimore: Johns Hopkins University Press, 1986).

${ }^{31}$ Kraus, Die Fackel, no. 33, 19 (1900). 
Jews were seen as a separate race or ethnic group and thus could not become "true" members of the nation. Herzl believed that even the most "assimilated" Jews were contained by an "invisible ghetto" in a gentile world. Any hope for Jewish-Gentile reconciliation was dashed, in Herzl's mind, by the Dreyfus Affair in France. ${ }^{32}$

Kraus, however, thought that Jews were discriminated against because their assimilation was incomplete and they remained in a "Wertvakuum" ("Value vacuum") of cultural and aesthetic ideals. ${ }^{33}$ Wealthy Jews, particularly in Vienna, preferred to live in a comfortable, gemütlich world of aesthetically pleasing illusions. The society created by these wealthy elites did not accurately reflect their reality. The Jewish middle class refused to acknowledge anti-Semitism, or if this were not possible, they simply blamed the ostjuden as the true cause of it. ${ }^{34}$ Kraus sought

${ }^{32}$ Arthur Hertzberg, ed., The Zionist Idea: A Historical Analysis and Reader (New York: Atheneum, 1959), 202 .

\section{${ }^{33}$ Beller, Vienna and the Jews, 133 ; Kraus, Eine Krone} für zion.

34 "As Jews with negative views of Jewishness and positive views of German culture in an anti-semitic ambiance, their [assimilated Jews] tendency was to seek ways for Jews to eliminate their Jewishness, and to place the primary blame on the Jews themselves." Theobald, The Paper Ghetto, 77. 
to tear down this façade of liberal freedom and instead to allow for the complete assimilation of Jews through the rejection of Judaism in all forms.

Acculturated Jews often rejected their former identities as Jews in order to become members of Austrian and German society. However, this society would not accept them as true citizens. By denying their past and their ancestry, these Jews were isolated on all sides and became dependent only upon one another. Steven Beller has described the Viennese Jewish cultural elite as "no longer really Jews, but neither were they Germans nor Austrians." 35 Lacking any concrete form of identity, these Jews embraced the world of high culture. Literature, theater, music, art, and intellectual exchange became the bonds which linked assimilation-seeking Jews together, as a substitute for the absence of the "true community" from which they were now excluded. ${ }^{36}$ According to Stefan Zweig, "nine-

${ }^{35}$ Beller, Vienna and the Jews, 214.

${ }^{36}$ This does not imply that high culture was simply a "Jewish" phenomenon. Non-Jews played a significant role in high culture throughout this period. From 1900 to the 1930s, however, the major contributions to high culture were overwhelmingly made by Jews. There is also some evidence that non-Jews were pressured into not associating with Jews, due to the anti-Semitic prejudices of Vienna. According to Beller, "the claim that culture was "verjudet" became a self-fulfilling prophesy, as non-Jews were warned 
tenths of what the world celebrated as Viennese culture in the nineteenth-century was promoted, nourished, or even created by Viennese Jewry." ${ }^{37}$

Kraus was not alone in viewing the acculturated Jews in a negative light or in doubting their success at assimilating. Walter Benjamin claimed that the political opinions of German-Jewish intellectuals were nothing but a thin veneer over their superficiality, resulting from a lack of a true identity. For Benjamin, the German-Jewish intellectuals, as a group, worked

to establish not political parties, but cliques, their literary function to produce not schools but fashions, and their economic function to set into the world not producers but agents. Agents or "smarties" who know how to spend their poverty as if it were riches and who make "whoopee" out of their yawning vacuity. One could not establish oneself more comfortably in an uncomfortable situation. ${ }^{38}$

off from all but the most conservative forms of culture." Beller, Vienna and the Jews, 216, 214-217; Schorske, Finde-Siècle Vienna, 5-7, 12-14, 116-175.

${ }^{37}$ Stefan Zweig, The World of Yesterday (Lincoln and London: University of Nebraska Press, 1964), 22. For a comprehensive analysis of Austrian high culture in the early twentieth century, see Schorske, Fin-de-Siècle Vienna.

${ }^{38}$ Walter Benjamin, "Der Autor als Produzent, " a lecture given in Paris in 1934 ; quoted in Benjamin, Illuminationen (Frankfurt am Main: Suhrkamp Verlag, 1961), 33-34. 
In reference to the same groups, Franz Kafka called them a "linguistic middle class," which consisted of "nothing but ashes which can be given a semblance of life only by overeager Jewish hands rummaging through them." 39 Both of these viewpoints echo Kraus's assertion of the "cardboardlike" nature of both Viennese culture and the state of quasi-assimilation of the Jews.

Kraus, Benjamin, and Kafka were exemplary because they did not want to "return" to the Jewish community or to Judaism as a faith. They believed in the Enlightenment notion of progress and truly thought that anti-semitism would disappear with the successful assimilation of the Jews. However, by isolating themselves from the Jewish community, they were now alienated from their Jewish heritages as well as their traditions and cultures. Although it is tempting to label Jewish critics as "selfhaters" or Jewish "anti-Semites," one must take the antiSemitic atmosphere in which they lived into account. ${ }^{40}$ The reactions of these men were a response to anti-Semitism.

${ }^{39}$ Max Brod, Franz Kafkas Glauben und Lehre (Winterthur, 1948) ; quoted in Benjamin, Illumenationen, 33-34.

${ }^{40} \mathrm{Gilman}$, Jewish Self-Hatred, 209-308. The subject of "Jewish self-hatred" will be dealt with in more detail in a later section. 
Hannah Arendt contrasted Kraus, Benjamin, and Kafka with the Viennese Jewish middle class method of "blaming the Ostjuden" as follows: "What gave their criticism its bitter sharpness was never anti-Semitism as such, but the reaction to it of the Jewish middle class, with which the intellectuals by no means identified."41

The German-Jewish middle class saw the typical caricature of the Eastern Orthodox Jew with his caftan and curls, the primary focus of anti-Semitic propaganda, as the source of anti-Semitism. However, a significant portion of German-Jewish intellectuals in the late nineteenth and early twentieth centuries created new caricatures and stereotypes in response to anti-Semitism and the drive for self-definition that redefined the causes of anti-Semitism. For men like Kraus, Benjamin, and Kafka, the "eastern Jew" became the image of the "good Jew," and this image was contrasted precisely with the quasi-assimilated or "acculturated Jew, who became the prototypical 'bad' Jew,"

${ }^{41}$ Hannah Arendt, "Introduction," in Walter Benjamin, Illuminations, edited with an introduction by Hannah Arendt, translated by Harry Zohn (New York: Harcourt, Brace, and World, 1968), 32, 36. 
the "Mauschel," and thus the reason that anti-Semitism remained. ${ }^{42}$

It is important to note that until the late nineteenth century, when this shift took place, the eastern Jew had normally been the focal point for feelings of insecurity and hatred on the part of western Jews. The eastern Jews were objects of derision because of their orthodox dress, their "corrupt" mixed language, their religious expression and adherence to strict dietary laws, thus becoming the quintessential "bad" Jew. As the nineteenth century drew to a close, the growing unease with the place of Jews in German and Austrian societies caused the focus of fear and anxiety to be placed on the acculturated Jew. According to Gilman, "the negative view of the Eastern Jew was displaced by the image of the assimilated Western Jew (or at least the Jew in the West), by Mauschel. This image was no longer associated with the Yiddish-speaking Eastern Jew, but with the Western Jew with his Jewish affectation."43

${ }^{42}$ Gilman, Jewish Self-Hatred, 270. ${ }^{43}$ Ibid. 


\section{Kraus and the "Jewish Question"}

\section{-The Problem of Language}

For Kraus, assimilation and social democracy were the only solutions to the Jewish Question. In the 1890 s and early years of the twentieth century, Kraus believed that the "Jewish Question," at least its more dangerous elements, could be solved through socialism. In his early letters, Kraus claimed that economic anti-semitism would be absorbed by Social Democracy, which made "all things equal, even noses." ${ }^{44}$ He also claimed that it was much more profitable to have a crooked nose than a straight one, at least for matters of finance. ${ }^{45}$ In fact, the "Jewish Question" continued because "certain gentlemen," the Zionists and the liberal Jewish middle class, simply refused to let it go.

Es liegt neuestens ein Verdienst darin, keine geradlinige Nase zu besitzen, und man kann sie darum nicht hoch genug tragen. Das sind die Herren, die es nie zugeben werden, dass der wirthschaftliche Antisemitismus von der Alles, auch die Nasen gleichmachenden Sozialdemokratie absorbirt werde; die den Gedanken nicht zu ertragen vermögen, dass die Deutschnationalen, im Kampfe gegen Slaven und Clericale vollauf beschäftigt, die leidige Judenfrage ruhen lassen könnten. Gerade in Oesterreich, wo die

${ }^{44}$ Kraus, "Eine Krone für Zion," 306.

${ }^{45}$ Ibid. 
Parteienkämpfe das Interesse für diese zeitweise ersticken, hat sich der Typus in seiner ganzen grotesken Aufdringlichkeit entfaltet. ${ }^{46}$

It seems to be newly profitable not to possess a straight nose, and if one has a crooked nose, one cannot hold it high enough. There are gentlemen, who will never admit that the economic antiSemitism of the masses will be absorbed by social democracy, which also makes noses equal. These gentlemen cannot endure the thought that the German nationals are perfectly occupied in their struggles against Slaves and Clerics, so that the unpleasant "Jewish Question" could be laid to rest. Precisely in Austria, where the parties' struggles occasionally suffocate interests in this question, the character [Jewish stereotype] has developed in all its complete grotesque intrusiveness.

Here, Kraus is echoing Karl Marx's ideas regarding the "Jewish Question." Marx believed that the "materialistic Jew" was a product of an exploitative capitalist system. For Marx, the solution to the "Jewish Question" was to get rid of capitalism in favor of socialism. This transformation of economic means would eliminate the economic-materialistic motivations for the "Jewish Question," and therefore (for Marx) the "Jewish Problem" in society. ${ }^{47}$

${ }^{46}$ Ibid.

${ }^{47}$ Karl Marx, "On the Jewish Question" in Early Writings, translated by Rodney Livingstone and Gregor Benton (New York: Penguin Books, 1992) ; Julius Carlebach, 
Additionally, Kraus posited that the anti-semitic slogans of the Christian Socialists, at least in the 1890s, were simply evidence of their overall political weakness.

Das politische Programm der Christlich-Sozialen wird von einem unbestimmten dumpfen Hasse bestimmt, der seinen prägnantesten Ausdruck, seine vollste Befriedigung in dem Wörtchen "Jud!" findet. Diese Weltanschauung erscheint bei einigen Herren noch insoferne vertieft, als diese sich auch des Ausrufes "Schandbube!" nicht bedienen können. ${ }^{48}$

The political program of the Christian-Socialists is determined by an indeterminable and vague hatred, which finds its most succinct expression, its fullest realization in the little word "Jew." This world view appears to deepen still in the works of several so that the cry "shame boy" is not sufficient for them.

"Shame boy" lacked the stereotypical associations of "Jew," which counted on an ingrained mentality of fear and hatred to inspire an instantaneous negative reaction. The Christian-Socialists had no real solutions to the problems in Viennese society, other than to blame the Jews. It is interesting to note that in Hugo Bettauer's 1923 novel Die Stadt ohne Juden, the political scene becomes stagnant after the Jews are thrown out of Vienna. With no one to

Karl Marx and the Radical Critique of Judaism (London, Henley, and Boston: Routledge and Kegan Paul, 1978).

${ }^{48}$ Karl Kraus, Frühe Schriften, ii, 116. 
blame, the conservative parties can only squabble among themselves.

It was not long before it became evident that all the parties, the Christian socialist as well as the Social-Nationalist, had as their common basis the portrayal of the Jew as an evil spirit, a bogeyman, and a scapegoat. Now that there were no Jews or people of Jewish descent in Austria this no longer attracted the public, and party politics became even more stupid and boring than before. ${ }^{49}$

Even more pointedly, Bettauer depicted the quick loss of any influence for "Swastika groups" and other antiSemitic parties.

Formerly the Hakenkreuzler (Swastika-men Bettauer's prototype of the Nazis to come) had attracted notice and aroused the masses with their posters. Bosel and other Jewish plutocrats had been called the rulers of Austria, had been reviled as vampires and oppressors. But now Bosel was living in London, and the Hakenkreuzler posters had become so colorless that no one bothered to read them anymore. One after another the papers that displayed the Hakenkreuz suspended publication....

In addition to critiquing the political scene, Kraus also contradicted the typical view of the western acculturated Jew in that he did not consider the fin-desiècle culture and society of Germany and Austria a worthy model for assimilation. Kraus instead favored the ideas

${ }^{49}$ Hugo Bettauer, Die stadt ohne Juden: ein Roman von übermorgen (Frankfurt am Main: Ullstein, 1988), 114. 
from the early days of liberalism, the Vormärz, or

Restoration period from the Congress of Vienna to the Revolutions of 1848. Under such a system, the "true" and "benevolent" assimilation he envisioned might have been possible but was in fact becoming more and more unlikely as anti-Semitism grew more hostile in twentieth-century Vienna. Rather than face the reality of a diverse and unstable political system that arose from the failure of the Austrian liberal movement, ${ }^{50}$ Kraus instead projected the political atmosphere of the early nineteenth-century upon his own time. The obvious result of this was his negative and pessimistic outlook. The strong central aristocratic authority was crumbling under the weight of nationalism and minority dissention. ${ }^{51}$ The newspapers, which had previously operated under heavy censorship with limited circulation,

${ }^{50}$ The "Constitutional Era" of Austria-Hungary lasted from 1867-1918. The years 1867-1879 are generally considered the time of "liberalism."

${ }^{51}$ During this period, Austria-Hungary recognized eleven nationalities: Germans, Hungarians, Czechs, Poles, Ruthenes (Ukrainians), Italians, Romanians, Slovaks, Slovenes, Croats, and Serbs. Marsha L. Rozenbilt, "Jewish Ethnicity in a New Nation-State: The Crisis of Identity in the Austrian Republic," in Michael Brenner and Derek J. Penslar, eds., In Search of Jewish Community: Jewish Identities in Germany and Austria, 1918-1933 (Bloomington and Indianapolis: Indiana University Press, 1998), 136. 
now manipulated public opinion to an extraordinary degree, reducing the reading public into mouthpieces of the press. ${ }^{52}$ Even more important to Kraus was his perception of the utter decay of language at the hands of Jewish intellectuals, particularly Heinrich Heine, through the feuilletons of the Neue Freie Presse. Thus Kraus created his "Torch" (Die Fackel) to burn through the corruption of modern liberalism and to seek to enlighten the populace by exposing the debased language of the press. However, simple social reform was not his major goal. Kraus hoped to teach people to read - "to read the public prints with skepticism and mistrust." ${ }^{53}$ If the reading public could learn to see the press for what it was, an instrument for controlling public opinion, then his destructive criticism would contribute to a positive social action. The unfounded stereotypical views of the populace, based on a latent hatred of Jews and reinforced by the press, could

${ }^{52}$ Both politically and economically, the Neue Freie Presse was the most influential newspaper in central Europe. Wickham steed, a contemporary observer, stated that "the greater part of what does duty for 'Austrian opinion' is dictated or suggested to the public by the editor-propreitor of the Neue Freie Presse." Wickham Steed, The Habsburg Monarchy (London, 1913), 187 ; quoted in Timms, Karl Kraus, Apocalyptic Satirist, 32.

${ }^{53}$ Timms, Karl Kraus, Apocalyptic Satirist, 41. 
finally be exposed for what they were: a scapegoat for the political, social, and economic problems of AustriaHungary. It is this sentiment that Bettauer drew from to create his fictional work and to illustrate the stupidity of anti-Semitism.

Key characteristics of both Die demolirte Literatur and Eine Krone für Zion show Kraus's focus upon language and its abilities to divide, categorize, and label. In Eine Krone für Zion Kraus claims to have heard a Galician Jew state: "Sie b $r \underline{\text { o }}$ Ch e n uns nicht" (They have not broken us) ${ }^{54}$ It is the particular pronunciation of brochen that is distinctive in this statement, and such dialectical variances marked the Ostjuden as unsuspecting targets for attack.

Rather than aspiring towards assimilation, the zionist Ostjuden consciously rejected western culture in favor of their own. Their goal was to maintain their eastern heritage in the face of westernization. Kraus exposed the multiple levels upon which anti-Semitism and Zionism operated in Vienna through the following ironic statement:

Es dreht sich ja doch nur um gewisse, im Pferch des Ghetto gezeugte Aeusserlichkeiten, die freilich unsere Hetzrabbiner in dem parodistischen Bewusstsein ihrer "Sendung" wie

${ }^{54}$ Kraus, "Eine Krone für Zion, " 310. 
ein Allerheiligstes conserviren möchten. Das Judentum wird sie opfern müssen: unschwer wird es seinen Gegnern die paar armseligen Handhaben entziehen. "Sie b $r \stackrel{\circ}{c}$ h e $n$ uns nicht!" hörte ich kürzlich einen ungeduldigen Herrn aus Tarnopol in einer zionistischen Versammlung wehklagend betheuern. Ich glaube, dass die ganze Judenfrage an diesem umgelauteten " $\circ$ " hängt. Zwischen dem Zuruf: "Schaut, dass ihr weiter kommt!" und dem verzagten: "Sie brochen uns nicht!" scheint mir blos ein kleines Missverständniss rein dialektischer Natur zu liegen.... ${ }^{55}$

It is of course only a question of certain formalities born out in the pen of the ghetto formalities which naturally our rabid rabbis would like to preserve in the parodistic consciousness of their "mission" as something supremely sacred. Jewry will have to sacrifice their mission: it will be easy to deprive their opponents of their few paltry chances. I recently heard an impatient gentleman from Tarnopol declare "They have not broken us!" in a zionist meeting [also, could be rendered as "They do not need us!" when pronounced in the local dialect]. I [Kraus] believe that the entire Jewish Question hangs on this rounded " $\mathrm{".}$ Between the cry, "Look, how far you have come!" and the despondent "They have not broken us!" appears to me a misunderstanding of a pure dialectical nature...

Through this example, Kraus shows that some of the problems of acculturation and adjustment to western Europe did not result from a simple "misunderstanding" on the part of the Ostjuden, but a conscious effort to separate themselves from Viennese society and "not to be broken."

${ }^{55}$ Ibid. 
With this interpretation, Kraus shows that some of the Ostjuden understood their position and were quite willing to remain outside society. On another level, due to the dialectical variations in pronunciation, an eastern vocalization of brochen could be heard as brauchen (need) by the Viennese. Kraus's emphasis on schaut makes this distinction clear. This "lack of need" reveals the plight of the Ostjuden and their attempts to assimilate into Austrian society and the reactions that they experienced. Thus, Kraus's attacks on "Jewish jargon" in the press and his attacks on "Jewish" journalists and intellectuals were driven, at least in part, by his desire to correct what he saw as their fundamental misuse of the German language, a misuse that only exacerbated zionist and anti-Semitic hostilities.

Kraus's satirical mission was to deconstruct ideologies in all forms, whether he personally disliked them or not. Thus his aim was to "counteract partisan imbecility (Parteiverblödung), slogan-mania (Schlagwörterwahn), and the 'befogging of the brain' (Benebelung der Gehirne) in whatever quarter they 
originated."56 Kraus launched Die Fackel with the following ideal in mind: Jewish and liberal corruption in matters of commerce, finance, and particularly the press were the actual causes of anti-Semitism. It was the Galician Jews, however, with their characteristic clothing and orthodox mannerisms, who became easy targets for attack by antiSemites. Kraus chose to attack the very elements he believed to be fostering anti-Semitism, rather than to attack the anti-Semites and their political parties. Much to his dismay, such tactics often earned him praise from anti-Semites, including Jörg Lanz von Liebenfels. ${ }^{57}$

In a special issue of Der Brenner devoted to Kraus, Liebenfels described him as "den Retter des ArioGermanentums" (savior of Aryan-Germandom). Kraus replied

${ }^{56}$ Kraus, Die Fackel, no. 38, 25 (1900) ; no. 90,17 (1901) ; no. 147, 23 (1902). See also, Edward Timms, Karl Kraus, Apocalyptic Satirist, 37.

${ }^{57}$ Liebenfels was a radical anti-Semite and maniacal supporter of the Pan-Germans. He founded the Ostara magazine to disseminate his opinions and was one of the chief sources utilized by Adolf Hitler in the formulations of his ideas on race and the Jews. Liebenfels thought well of Kraus due to the latter's attacks on the Jewish presses and is reported to have once said, "I have never been associated with Karl kraus. I do not know the exact measurements of his skull...Karl Kraus is a genius, a genuine genius, for his work is that of a pioneer and a creator. That alone says something about his true race." Hamann, Hitler's Vienna, 220, 216-222. 
in an essay in Die Fackel by saying "Wie das zugeht, weiß ich nicht, da doch diese Rassenantisemiten auch den Satz aufgestellt haben 'Aus der Rasse kann man nicht austreten'" (How that happens, I do not know, for these race antiSemites have also said 'One cannot escape from one's race'), a well-known phrase by Liebenfels. ${ }^{58}$ As a result of such statements, Kraus attempted to distance himself from both anti-Semites and the "corrupt" members of the Viennese Jewish community. In a 1913 piece, Er ist doch e Jud (He is just a Jew), Kraus attempts to explain, however cryptically, his stance on the "Jewish Question:"

Ich weiß nicht, ob es eine jüdische Eigenschaft ist, das Buch Hiob lesenswert zu finden oder ob es Antisemitismus ist, ein Buch Schnitzlers in die Ecke des Zimmers zu werfen. Ob es jüdisch gefühlt ist oder deutsch, zu sagen, daß die Schriften der Juden Else Lasker-Schüler und Peter Altenberg Gott und der Sprache näher stehen, als alles, was das deutsche Schrifttum in den letzten fünfzehn Jahren, die Herr Bahr lebt, hervorgebracht hat. ${ }^{59}$

I do not know if it is a Jewish quality to find the Book of Job valuable reading, or if it is antisemitic to throw a book by [Arthur] Schnitzler into the corner of the room. Or if it is a Jewish feeling or German to say that the works of the Jews Else Lasker-Schüler and Peter Altenberg stand nearer to God and to language

${ }^{58}$ Karl Kraus, "Er ist doch e Jud," in Untergang der Welt durch schwarze Magie, ed. by Heinrich Fischer, (Munich: Kösel-Verlag, 1960), 332.

${ }^{59}$ Ibid, 335. 
than all of the German works produced in the last fifty years, in which Mr. [Hermann] Bahr has lived.

Here Kraus attempts to show that some Jewish writings are pure, but that others are corrupted through their misuse or abuse of language. Although the writings of Lasker-Schüler and Altenberg reflect the "good" qualities of Jewish literature, their contributions are overshadowed by the "decadence" and "linguistic corruption" in the works of other Jews. Despite the anti-Semitic connotations of some of Kraus's statements, he did hold a moral standard, that of pure, uncorrupt language, from which he attacked those persons whom he saw as contributing to the cultural decline of Europe.

Kraus attempted to create a Jewish "Other" as a focal point for his negativity and to distance himself from it, rather than succumb to "self-hatred" as did Otto Weininger and many others. For Kraus, this "Other" was the liberal, acculturated Jews whom he regarded as fostering antiSemitism through their use of language, their manners, and their actions. ${ }^{60}$ Kraus selected his targets based on their

${ }^{60} \mathrm{Gilman}$, Jewish Self-Hatred, 139-208. For a critique of the concept of "self-hatred," see Alan Janik, "Viennese Culture and the Jewish Self-Hatred Hypothesis: A Critique," 
use of language and political hypocrisy. Popular and wellrespected writers such as Hermann Bahr, Hugo von Hofmannstahl, Felix Salten, Maximilian Harden, Alfred Kerr, Theodor Herzl, Heinrich Heine, and even Sigmund Freud became "bad Jews," and were perceived as the antithesis of the Krausian "good Jew" due to their misuse and corruption of language. They were opposed by "good Jews," such as Otto Weininger, Peter Altenberg, Else Lasker-Schüler, who elevated language in the classical sense of Goethe. It is significant that Kraus is attempting to show that the "Other" is not necessarily the ostjuden, the target of most anti-Semites, but rather the acculturated western Jew who is debasing German culture through language.

Kraus drew a distinction between correct or "nonJewish" (non-mauscheln) as "good," and the "bad" incorrect language of the Jews. One significant example can be found in another attack by Kraus on Felix Salten. Entitled JüdeInde Hasen ("Rabbits with Jewish Dialect"), the

in Ivar Oxaal, Michael Pollack and Gerhard Botz, eds., Jews, Anti-Semitism and Culture in Vienna (London: Routledge and Kegan Paul, 1987), 75-8; Ritchie Robertson, "The Problem of 'Jewish Self-hatred' in Herzl, Kraus and Kafka," Oxford German Studies 14 (1985) : 92-99. Both authors claim that "self-hatred" is an insufficient label for addressing the complexities of identity, either with regard to the Jews or to any marginalized group. 
original story tells of a group of hares who discuss the appearance of a man in their forest. Kraus believed that the story was actually representative of the Jewish minority in Austria and quotes from Salten's work to support his position and then reinterprets the dialogue.

This rabbit, who is clearly no youngster and knows his way around, talks like a book the Zsolnay Publishing House is putting out.... Nothing gets by the instinct of animals. But it is amazing how they assimilated the enemy's speech. Perhaps mimicry as a defense against persecution? One easily gets used to Jewish dialect being used in times of danger; when they are among themselves, they know how to talk German. ${ }^{61}$

From this perspective, Kraus presumes that the correct and precise use of German was one of the first things to be dropped when German Jews were threatened. Salten is simply writing in a "Jewish" fashion using the special or "hidden" language of the Jews to represent fear or emotions among threatened groups. Kraus maintains that the Jews, at least the western Jews, possess a special language that marks them as different and separate from the rest of society. The Yiddish of the Ostjuden is different; it is their true cultural language. The acculturated Jew, however, when

${ }^{61}$ Segel, The Viennese Coffeehouse Wits, 108. 
threatened, would theoretically speak mauscheln, or a garbled mixture of Yiddish and Modern High German. ${ }^{62}$ Linguistic racism is often overlooked or underemphasized in studies of this period. Sander Gilman's Jewish Self-Hatred: Anti-Semitism and the Hidden Language of the Jews is a notable exception which demonstrates how accent, intonation, grammar, and vocabulary are used to marginalize and differentiate segments of a population. Anti-Semites were not necessarily concerned with the Yiddish language of the eastern Jews. ${ }^{63}$ Instead certain groups, which might include kraus, focused their attacks on the "Jewish Jargon" which "masqueraded as the purest and most irreproachable German."64 Gilman's study shows how Austrian and German writers throughout the nineteenthcentury, including Wilhelm Marr, Eugen Dühring, Heinrich von Treitschke, and Theodor Billroth, argued that acculturated Jews were still Jews and spoke German in a

${ }^{62} \mathrm{John} \mathrm{T}$. Waterman, A History of the German Language, revised edition (Washington: University of Washington Press, 1966, reprint Prospect Heights (IL): Waveland Press Inc., 1991), 119.

${ }^{63}$ Gilman, Jewish Self-Hatred, 233-235.

${ }^{64}$ Jacques Le Rider, Modernity and Crises of Identity: Culture and Society in Fin-de-Siècle Vienna, translated by Rosemary Morris (New York: Continuum, 1993), 266. 
peculiarly Jewish way. Such sentiments caused Germanspeaking Jews to become obsessed with linguistic purity and precision. ${ }^{65}$ Kraus saw proper German as the antithesis of the garbled German of the Ostjuden that was branded "Jewish" by the anti-Semites, and also the mauscheln utilized by acculturated Jews to reflect pejorative "Jewish" characteristics.

Kraus's accusation of a "hidden language" of the Jews is reminiscent of Richard Wagner's anti-Semitic essay, Das Judentum in der Musik, first published in 1850. Wagner, like Kraus, considered the worst offence of Judaism to be the corruption of the arts and literature. He claimed that the Jews were incapable of a pleasing artistic presentation because of their very nature as "inferior" and

"aesthetically unsuitable" people. This idea carries over into Wagner's views on language and the inability of Jews to master the language of the country they were living in since they spoke Yiddish as their "natural tongue." 56

${ }^{65}$ Some examples are Eduard Engel's book Sprich deutsch! Ein Buch zur Entwelschung! (Speak German! A Book for Assimilation, or "how not to be an alien"), 1917, and Fritz Mauthner's Beiträge zu einer Kritik der Sprache (Contributions to a Critique of Language), Frankfurt and Berlin, 1982 .

${ }^{66}$ Wagner spoke out against the Germanic embrace of liberalism with the statement, "all our [German] liberalism 
Kraus also promoted the Jewish stereotypes of money and capitalism with regard to the Jews and linked this association with their "hidden" language. Careful not to exclude himself as a non-Jew, Kraus nevertheless drew a firm line between materialistic, linguistically-corrupt "bad" Jews, and non-materialist, linguistically-precise "good" Jews. He even suggests that the "hidden" language of the Jews is in fact materialism:

Ich weiß nun doch nicht, was heute jüdische Eigenschaften sind. Wenn es nur eine gibt, die alle anderen...der singende Tonfall, in dem sie ihre Geschäfte besorgen und besprechen, so sage ich, daß ihn die anderen auch treffen könnten, denn es ist der Tonfall, der das Rollen des Geldes wohlgefällig begleitet. Es ist die

was a somewhat confused intellectual game, in so far as we proposed freedom for the Jews with no knowledge of the race, indeed with a distaste for any contact with them." Wagner claimed that the move towards Jewish emancipation came only from a confused thread of liberalism. Going still further, he said that the Jews took full advantage of such benevolent attitudes in order to place themselves in positions of authority. Wagner maintained that "the Jew is more than emancipated, he is the ruler. And he will continue to rule as long as money remains the power to which all our activities are subjugated." Richard Wagner, "Judaism in Music" in Stories and Essays, edited by Charles Osborne, (London: Peter Owen, 1973), 24, 25 ; Alan David Aberbach, The Ideas of Richard Wagner: An Examination and Analysis of His Major Aesthetic, Political, Economic, Social, and Religious Thoughts (New York: University Press of America, 1984); Ulrich Muller and Peter Wapnewski, eds., Wagner Handbook, translated by John Deathridge (Cambridge, Mass: Harvard University Press, 1992). 
Sprache der welt, es ist ihre sehnsucht und wir dürfen sie, müssen sie darum als einen jüdischen Zug ansprechen, weil es die Mission der Juden war, dank ihrer Überredungsgabe, Ausdauer und größeren Übung im durch die Welt kommen, dieser eben diese Eigenschaften anzuhängen. ${ }^{67}$

Well, I just don't know what today are Jewish qualities, but if there is one out of all the others...it is the song-like tone of voice in which they manage and discuss their businesses. I also say that the other qualities could be discerned in it too, for it is this tone which is such a pleasing companion to the rolling of money. It is the language of the world, it is its longing, and we may, we must, claim it as a Jewish trait because it was the mission of the Jews, thanks to their gift of persuasion, perseverance, and greater training at moving through the world, to which these qualities are attached.

It is important to note that Kraus still praised the original qualities of the Jews: their gifts of persuasion, perseverance, and mobility. However, he connected these positive "foundational" traits to the negative "modern" qualities of capitalist-materialism with which he indicted his contemporaries.

${ }^{67}$ Kraus, "Er ist doch e Jud," 333. This is again similar to Marx's views of Jews as a creation or exponent of capitalism and materialism. Both Kraus and Marx sought to eliminate the "Jewish" money-lender or speculator stereotype by moving away from a capitalist-materialistic system. Kraus favored a liberal-socialism, while Marx envisioned a socialist, and eventually communist, utopia. Marx, "On the Jewish Question" in Early Writings ; Carlebach, Karl Marx and the Radical Critique of Judaism. 


\section{Karl Kraus: "Self-Hater" or "Modern Day Prophet"?}

As a German-speaking Jew with such a negative view of western Jews, it is easy to see why Kraus felt such a pressing need to distance himself from the very group in which he could have been placed. Kraus was battling for the right to be included in German life and literature, even if he claimed that such culture was unworthy. He was in an awkward predicament, fighting what could be termed his "evil Jewish nemeses" in literature and politics, Heinrich Heine and Theodor Herzl. Kraus's response was to create the image of a linguistically perverted "evil" western Jew so that he himself might be accepted into "good" German society.

Was Karl Kraus a Jewish anti-Semite? Despite the fact that some of his writings and views echoed those of selfdeclared anti-semites, Kraus's own situation is too complex to be categorized that simply. Kraus did attack Jews, but he also attacked non-Jews whom he perceived to be contributing to the decline of his time. Kraus published works by anti-semitic authors in his journal, most notably articles by Houston Stewart Chamberlain. However, he also attacked hypocritical legislation and policies, political 
corruption, sexual conservatism, and at times championed the rights of women.

It is clear that Kraus looked upon the westernized acculturated Jews as the "Other" or "bad" Jew because they had failed to assimilate fully and had espoused Jewish stereotypes in their writings. Kraus also sought to protect the ostjuden from exploitation by the zionists by encouraging them towards complete assimilation. The careful distinction between "good" and "bad" lies with Kraus's perception of the western Jews. In Kraus's view, the quasi-assimilated western Jew was closely associated with everything that was negative or perverse. "Good" Jews would assimilate completely, bringing an end to antiSemitism and the "Jewish Problem." Sigurd Paul Scheichl, in a study of Kraus's political views, described Kraus's view of assimilated Jews as follows:

Kraus's attitude to Judaism developed in perfect harmony with his Kulturkritik in so far as the Jews seemed to be part of all the contemporary phenomena which he judged unfavorably: liberalism, liberal corruption of the press and the economy, forgetfulness of nature in bourgeois morality. ${ }^{68}$

${ }^{68}$ Sigurd Paul Scheichl, "Karl Kraus und die Politik," vol. 3 (Ph.D. diss., University of Innsbruck, 1971), 859; quoted in Le Rider, Modernity and Crises of Identity, 258. 
While Kraus consistently used contemporary anti-Jewish clichés and stereotypes, he nonetheless denied that his critiques exemplified self-hatred. In one of his later works, Kraus explicitly praised Judaism:

[Ich] in der freien Verfügung geistigen Hohns, in der Ehrerbeitung für das geschändete Leben und die besudelte Sprache die Naturkraft eines unkompromittierbaren Judentums dankbar erkennt, und über alles liebt: als etwa von Rasse und Kasse, von Klasse, Gasse und Masse, kurz jeglichem Hasse zwischen Troglodyten und Schiebern unbehelligt in sich beruht. ${ }^{69}$

In the spiritual mockery at my candid disposal, and in the veneration for desecrated life and defiled language, which I love over everything, I thankfully recognize the natural force of an uncompromising Judaism as something that exists in and of itself, unmolested by race, money, class, the ghetto and the masses, in short by any sort of hatred between Troglodytes and profiteers.

Instead, Kraus believed that he was attacking his own people in a fashion similar to the old Testament prophets' castigation of the Israelites in times of spiritual weakness. Through such attacks, Kraus hoped to purge the corruptive elements that were oppressing the Jews: antiSemitism, the now "corrupt" and weakened liberalism, and

${ }^{69}$ Karl Kraus, "Warum die Fackel nicht erscheint, " in Die Fackel (München: Kösel-Verlag, 1968-1973), nos. 890905,38 ; quoted in Beller, Vienna and the Jews, 1867-1938, 228-229; also Harry Zohn, Karl Kraus and the Critics (Columbia: Camden House, 1997), 22. 
capitalist materialism. Additionally, Kraus's attacks on Heinrich Heine and other Jewish figures must be balanced with his passionate support of some of his contemporaries: Else Lasker-Schüler, Peter Altenberg, and Berthold Viertel. ${ }^{70}$ When compared to Otto Weininger's self-hatred, Kraus's polemical nature seems to favor a "prophetic" stance. ${ }^{71}$

Despite Kraus's apparent anti-Jewish sentiments, Frank Field has argued that Kraus, always full of contradictions, was a "Jew who had renounced Judaism and yet, for that very reason, felt even more acutely Jewish than before."72 Erich Heller, recalling one of Kraus's own statements, has written that Kraus's anti-Semitism was "a new form of the prophet's indignation at the worshipers of the Golden

${ }^{70}$ S.S. Prawer, "Jewish Contributions to German Lyric Poetry," in Leo Baeck Institute Year Book VIII (1963) : 163.

${ }^{71}$ Gilman, Jewish Self-Hatred. For Weininger, see Nancy Harrowitz and Barbara Hyams, eds., Jews and Gender: Responses to Otto Weininger (Philidelphia: Temple University Press, 1995) ; Ritchie Robertson, The "Jewish Question" in German Literature, 1749-1939 (Oxford: Oxford University Press, 1999) ; Chandak Sengoopta, Otto Weininger: Sex, Science, and Self in Imperial Vienna (Chicago: University of Chicago Press, 2000).

${ }^{72}$ Field, The Last Days of Mankind, 8. 
Calf."73 Kraus was renouncing the "corrupt" Judaism that he saw as contributing to the cultural, ethical, and intellectual decline of western society. In nearparadoxical terms, Kraus hoped to reverse the decline of Europe, in which "corrupt" assimilated Jews were a part, by preaching to other Jews, while at the same time distancing himself from the Jewish community.

According to Berthold Viertel, a close friend of Kraus, the explanation for this apparent paradox is that Kraus is an "Erzjude," or arch-Jew. ${ }^{74}$ Though such a figure might seem a heretic and a betrayer of the success of the Jews, Viertel maintained that Kraus wrote from a critical perspective. As a Jew, Kraus's critical orientation was anti-Jewish. As a guardian of classical German cultural values, he was anti-German. As a proud Viennese profoundly

${ }^{73}$ Erich Heller, In the Age of Prose (New York: Cambridge University Press, 1984), 37. Kraus's phrase is "aber [ich] den Tanz um das goldene Kalb nicht mehr mitmache..." (but [I] no longer participate in the dance around the golden calf). Kraus, "Er ist doch e Jud," 335.

${ }^{74} \mathrm{~A}$ term first used by Martin Buber, in reference to himself, which can be rendered "arch-Jew", in the sense of an Old Testament prophet. Zohn, "Karl Kraus: "Jüdischer Selbsthasser " oder "Erzjude"?" ; idem. Karl Kraus and the Critics. For a further discussion on the influence of Buber and the "Hasidic Spirit" which is connoted with "Erzjude," see Steven Aschheim, Brothers and Strangers, $131-135$. 
rooted in Austria, Kraus was anti-Austrian. ${ }^{75}$ Paul Neumarkt claimed that Kraus assumed the "stance of Jeremiah and Isaiah" and that his call for "social justice and compassion with our fellow man has the ring of the old Testament."76 In his 1913 essay Er ist doch e Jud, Kraus casts himself in the role of a prophet from the old Testament. Kraus was convinced that Judaism in its original foundations was good, that Jews had departed from the "true path" and were now guilty of worshipping the "golden calf" of capitalist-materialism:

Ich glaube von mir sagen zu dürfen, daß ich mit der Entwicklung des Judentums bis zum Exodus noch mitgehe, aber den Tanz um das goldene kalb nicht mehr mitmache und von da an nur jener

Eigenschaften mich teilhaftig weiß, die auch den Verteidigern Gottes und Rächern an einem verirrten Volk angehaftet haben. ${ }^{77}$

I believe I may say of myself that I go along with the development of Jewry right up to Exodus,

${ }^{75}$ Berthold Viertel, Karl Kraus: Ein Charakter und die Zeit (Dresden: Kämerer, 1921)56, 89 ; quoted in Zohn, Karl Kraus and the Critics, 19. Though others accused Kraus of being an anti-Semite, leading Catholic intellectuals in Austria supported Viertel's claims and saw Kraus as an "Erzjude." Sidney Rosenfeld, "Karl Kraus: The Future of a Legacy" Midstream (April 1974) : 78.

${ }^{76}$ Paul Neumarkt, "Kraus, Tucholsky, Felix Mendelssohn: A Trio of Apostates" Jewish Currents 27 (December 1973) : 41 .

$$
{ }^{77} \text { Kraus, "Er ist doch e Jud," } 335 .
$$


but no longer participate in the dance around the golden calf, and from there on only know of sharing those qualities that are connected only with God's defenders and avengers against a people that has gone astray.

Kraus attempted to exempt himself from criticism or "Jewish" associations by isolating himself from other ideological standpoints and by refusing to make alliances that might have otherwise aided him in his efforts. The ethical foundation of his writings lay in the complete independence of Die Fackel from ideological or financial obligations or biases. ${ }^{78}$ Kraus's ideal was to be "a writer without preconceptions who observes things without party spectacles" (das Ideal eines voraussetzungslosen, die Dinge ohne Parteibrille betrachtenden Schriftstellers). ${ }^{79}$ Kraus's absolutist mentality forced him to adopt a desperate polemic with his readers, urging them to think for themselves and to stand up against the mindlessness of a

${ }^{78}$ Kraus financial independence allowed him to publish Die Fackel without sponsorship or dependence upon advertising. Kraus was thereby free from the external pressures or limitations that restricted other publications such as Maximilian Harden's Die Zunkunft. Edward Timms, Karl Kraus, Apocalyptic Satirist: Culture and Catastrophe in Habsburg Vienna (New Haven: Yale University Press, 1986), 36.

${ }^{79}$ Karl Kraus, Die Fackel, no. 90, 17 (1901); quoted in Timms, Karl Kraus, Apocalyptic Satirist, 37. 
technologically innovative but intellectually and morally starved society based on capitalism and mass culture. 


\section{Chapter IV: Austria and Weltgericht}

\footnotetext{
"It is the mission of the press to disseminate intellect and at the same time destroy the receptivity to it." 1

"The making of a journalist: no ideas and the ability to express them." ${ }^{2}$

"One greater than kings had arrived - the newsboy." 3
}

\section{A Short-Lived Faith in Social Democracy}

After the triumph of the Christian Socialists under Lueger in 1897, Karl Kraus condemned the Viennese voting public. For Kraus, the success of Lueger's opportunistic anti-Semitism only confirmed the political backwardness of Austrian politics. He argued that Lueger and his antiSemitic supporters gave "popular expression to this basest of all political ideas [anti-Semitism]" and were "undoubtedly a true reflection of the people's will."4 However, Kraus believed that the Christian Socialists' political incompetence, hitherto hidden by anti-semitism, would soon be unmasked. Kraus's one hope for Lueger was

${ }^{1}$ Karl Kraus, quoted in Harry Zohn, Karl Kraus (New York: Twayne Publishers, 1971), 76.

${ }^{2}$ Ibid, 163 .

${ }^{3}$ Mark Twain, A Confederate Yankee in King Arthur's Court (New York: Heritage Books, 1948), 182.

${ }^{4}$ Karl Kraus, Frühe Schriften, ii, edited by Joh. J. Braakenburg (München: Kösel-Verlag, 1979), 31-32. 
that he might rid Vienna of "Jewish" capitalism and the malignant "Jewish" press. By 1900, however, Lueger had relaxed his confrontational posture with regard to the Jews and had entered into agreements with prosperous Jewish businessmen. To Kraus, this confirmed that anti-semitism was merely a political instrument and that anti-semites had no intention of acting decisively on the "Jewish Question:"

\begin{abstract}
Some obscure Jews have been beaten up, a few teachers have not been promoted-but Rothschild's profits from municipal businesses grow. And since Herr Benedickt [editor-in-chief of the Neue Freie Presse] has for the last twenty years successfully persuaded the Viennese Jews that they have no real interest other than the balance sheet of Wittkowitz [Rothschild-owned iron works] it is therefore no surprise that the readers of the Neue Freie Presse feel very comfortable under the regime. The impartial observer finally discovers that there is only one partisan antiSemitic lie: namely that all Jews are clever people... ${ }^{5}$
\end{abstract}

With the Liberal Party politically isolated and the conservative Christian Socialists in power, Kraus and other Jews turned increasingly to the Social Democratic Party under Viktor Adler. The Austrian Social Democratic Party maintained that the Jews within the Empire did not

${ }^{5}$ Karl Kraus, Die Fackel, (München: Kösel-Verlag, 19681973), 40 (May 1900), 5 ; quoted in Wistrich, The Jews of Vienna in the Age of Franz Joseph, 511. 
constitute a separate nationality or race. Instead of encouraging "destructive" nationalism and ethnic conflict, the Social Democrats allowed Jews and other groups into their party so that they could aid in the class struggle and escape capitalist hegemony. Thus, at least until 1903, Kraus hoped that Social Democracy would encourage and allow mass Jewish assimilation along the paths he envisioned: renunciation of a "Jewish" identity and complete immersion in western society.

However, Kraus's somewhat innocent and naïve hopes for socialism faded in the first years of the twentieth century. Kraus came to believe that the Social Democratic Party was sliding into the same sort of "value vacuum" of social activity and progress as the rest of Viennese society. Thus he claimed:

Auch diese Partei hat die Wirkungen des intellectuellen und moralischen Niederganges unseres öffentlichen Lebens reichlich verspürt. Wer von ihrem Eintritt in die Politik eine Hebung des politischen Niveaus erhofft hatte, ist jetzt stark ernüchtert. ${ }^{6}$

This party [Social Democrat] too has felt in full measure the effects of the intellectual and moral decline of our public life. Anyone who had expected its admission into politics to bring about a rise of political standards has had to have second thoughts.

${ }^{6}$ Karl Kraus, Die Fackel, no. 47, 20 (1900). 
The failure of the Social Democrats to follow their idealistic claims was enough to disillusion Kraus. However, it was his reaction to the party paper, the Arbeiter zeitung, that led to a formal break with the Social Democrats in 1903. Kraus first claimed that Social Democracy worked against its own ends by encouraging embourgeoisiement. The Arbeiter Zeitung only became popular with Jewish readers after it was attacked by Catholic anti-Semites, according to Kraus, while Die Fackel refused to acknowledge such sentiments. ${ }^{7}$ It was even more hypocritical for the Arbeiter zeitung to accept advertisements from exploitative capitalist companies, a failing which Kraus continually pointed out. He considered this action to be the "worst betrayal of a mission in which I believed, and in which I still believe" (schlimmster Verrath an einer Mission, an die ich glaubte und noch glaube).$^{8}$

${ }^{7}$ Ibid, no. 40, 5 (1900). It is true that Die Fackel is not welcome in those homes in which the Arbeiter zeitung is eagerly read since its daily derisions by anti-semites (Wahr ist, dass in jenen Haüsern, in denen die "ArbeiterZeitung" seit ihren täglichen Beschimpfungen der Antisemiten gerne gelesen wird, die "Fackel" keinen Zutritt hat).

$$
{ }^{8} \text { Ibid, no. 21, } 31 \text { (1899). }
$$


Kraus's early admiration of the Social Democratic Party seems to have stemmed from his left-wing intellectual response to the anti-Semitic environment in Vienna, not from some identification with the plight of the working class or of a sincere interest in socialist economic ideology. It is little wonder then that his support quickly evaporated in the day-to-day heat of the Viennese political system. It must also be noted that Kraus was slowly adopting a much more conservative response to the "Jewish Question" than that offered by Social Democracy. Kraus's early solution for the "Jewish Question" was grounded in the notion of complete assimilation. While at first he believed this to be possible through the openness of liberalism and then social democracy, Kraus came to realize that these ideologies were too optimistic in light of anti-Semitic hostility and inflexibility in Vienna. ${ }^{9}$

Kraus responded to the conservative reactionaries, using their own language and stereotypes to attack them. Through this conservative veil, he came to see that Jewish

${ }^{9}$ It is important to note that kraus was not permanently hostile to the Social Democratic Party. Beginning in 1919 and continuing until the late 1920s, Kraus came to support the Social Democratic Party in response to the radicalization of conservative nationalist parties and the chaos surrounding the dissolution of the Habsburg Empire following the First World War. 
assimilation would be extremely difficult, but not impossible. Through the complete rejection of everything Jewish and the whole-hearted adoption of German culture, a small number of Jews could assimilate themselves into Austro-German society. Kraus, convinced that his idea for assimilation was the most realistic, nevertheless acknowledged the implications of his formulations:

Insofern es aber Juden gibt, welche gewisse accidentelle Eigenschaften ihres Lebenskreises, die sie selbst als culturhindernde Elemente abgestreift haben, klar erkennen und tadeln, kann man bisweilen von jüdischen Antisemiten und antisemitische Juden hören. ${ }^{10}$

Insofar as there are Jews who clearly recognize and condemn certain accidental characteristics in their social circles which they themselves have rejected as culturally regressive elements, one can now and then hear of Jewish anti-Semites and anti-Semitic Jews.

This is further evidence of Kraus's shift towards a personal solution to the "Jewish Question" while at the same time recognizing the fragility of his situation and his negativity with regard to Jews as a social group. He chose to create an ideal vision of assimilation into an enlightened liberal world for himself and for others who faced similar problems.

${ }^{10}$ Kraus, Die Facke1, no.24, 6 (1899). 


\section{The Dreyfus Affair and the Krausian Reaction}

In November of 1894, a Jewish officer in the French Army was arrested for allegedly selling military secrets to Germany. This case was not settled until July of 1906 , when the officer, Captain Alfred Dreyfus, was exonerated by the French Supreme Court. ${ }^{11}$ Dreyfus, from an old Jewish family in Alsace, considered himself to be assimilated and was a patriotic Frenchman. ${ }^{12}$ After news of an army cover-up was released, a political scandal erupted in France that grew so that "no political party, no institution, no

${ }^{11}$ Dreyfus was quickly and quietly convicted on the basis of circumstantial evidence, stripped of his rank and sent to Devil's Island off the coast of South America. Dreyfus, who never saw the evidence against him, maintained his innocence. For two years, French military secrets continued to be leaked to the Germans. Another chief military officer (ironically an admitted anti-semite) reopened the investigation and determined that the true culprit was not Dreyfus, but most likely a certain Major Walsin Esterhazy. When faced with the evidence, the French army decided to save face and acquit Esterhazy, leaving Dreyfus to serve out the remainder of his sentence. After great public controversy, Dreyfus was tried a second time in 1899, and again found guilty, but this time with "extenuating circumstances." He received a presidential pardon later that year and was allowed to return to France, but was not fully cleared until 1906. John Merriman, $A$ History of Modern Europe, vol. 2 (New York: W.W. Norton and Company, 1996), 940-943.

${ }^{12}$ Dreyfus's family moved from Alsace to Paris after the German annexation in 1871 . 
religious group, no family, no thinking individual was left unaffected."13 The French novelist Émile Zola, along with several others, came to Dreyfus's aid. Zola published "J'accuse," a feuilleton denouncing the French army and government for concealing the true nature of the case. ${ }^{14}$ The Church and right-wing conservatives quickly responded and moved to support the government against what they believed was a conspiracy of Jews and Freemasons. ${ }^{15}$

The consequences of the Dreyfus Affair spread across Europe as other Jews attempted to show their support for Dreyfus in the face of accusations of a "Jewish conspiracy." From Vienna came Theodor Herzl, acting as a correspondent for the Neue Freie Presse. Herzl and others from the major news organizations of the world saw the Dreyfus Affair as a critical event in the fight for Jewish emancipation, and the plight of French Jews was felt by many. It can indeed be argued that Herzl's Zionist movement became crystallized in his mind as a result of the

${ }^{13}$ Robert S. Wistrich, Between Redemption and Perdition: Modern Anti-Semitism and Jewish Identity (London and New York: Routledge, 1990), 133.

${ }^{14}$ After his campaign, Zola was hounded by the French government and forced to leave Paris. He died a short time later.

${ }^{15}$ Merriman, A History of Modern Europe, $940-943$. 
Dreyfus Affair. ${ }^{16}$ Herzl was in Paris at the Ecole Militaire when Dreyfus was stripped of his rank. For Herzl, the "howling of the mob outside the gates of the parade ground, shouting 'à bas les Juifs,' (down with the Jews; which mimicked the German Juden 'raus) transformed him into the zionist that he was to be." 17

Kraus saw the Dreyfus Affair as yet another example of the existence of a sort of "transparent ghetto" and the failure of Jews to assimilate into western society. Kraus attacked the liberal "Jewish" newspapers of the world, not just the Austrian, but German, French, British, and American papers. According to Theobald, Kraus believed that these papers were "introducing world-wide Jewish solidarity behind a Jew who was on trial for a crime which, even if he was guilty, had nothing to do with his Jewishness," at least before it was sensationalized into a question of anti-Jewish action by the press. ${ }^{18}$

${ }^{16}$ Arthur Hertzberg, ed., The Zionist Idea: A Historical Analysis and Reader (New York: Atheneum, 1959), 45-51.

${ }^{17}$ Ibid, 202.

${ }^{18}$ John Theobald, The Paper Ghetto: Karl Kraus and Anti-Semitism (Frankfurt am Main: Peter Lang, GmbH, 1996), 73 . 
For Kraus, the liberal newspapers of Vienna, ever championing the Enlightenment values of the individual, "invented" the story of Dreyfus as the victim of an antiSemitic monster to sell newspapers and to defend their own selfish interests on the Stock Exchange. This view was also supported by the Social Democrats through the Arbeiter zeitung at the time. ${ }^{19}$ The absurdity of the Dreyfus Affair for Kraus was the decision of the liberal press and the Jewish community to let the honor of world Jewry hang on the guilt or innocence of one man. It would be better that the French captain be unjustly convicted for treason than to create a world Jewish movement to rescue him because that would only cause an increase in the level of general fear of an "international Jewish movement" and hostility towards Jews everywhere. The support of "Jewish" concerns and issues worked directly against the assimilation for which Kraus was calling. Additionally, the Viennese press was creating public hostility toward the French Army, while at the same time ignoring the actions of

${ }^{19}$ Robert S. Wistrich, The Jews of Vienna in the Age of Franz Joseph (Oxford: Oxford University Press, 1989), 512 . 
its own government against Jews. For Kraus, the ultimate hypocrisy of their campaign was blindingly clear. ${ }^{20}$

Kraus was aided in his attack on the liberal press's pro-Dreyfus campaign by Wilhelm Liebknecht, a leading

Social Democrat in Germany. Liebknecht wrote four articles against the Dreyfusards, which were published only in Die Fackel. ${ }^{21}$ Liebknecht believed that Dreyfus was guilty, and any effort on the part of Jews to rescue him would only result in a backlash of anti-semitic sentiment. Going still further, Liebknecht asserted that "any campaign in his [Dreyfus's] favour must be motivated and tainted by selfish Jewish financial interests," a perspective shared by anti-Semitic groups. ${ }^{22}$ It is significant to note that

${ }^{20}$ Ibid, 512-513; Theobald, The Paper Ghetto, 73.

${ }^{21}$ Liebknecht chose to publish his articles in Die Fackel, to which Kraus readily agreed. As a result, both the articles and Kraus's journal circulated widely throughout Europe during this period. A majority of Austrian and German Social Democrats (with the exception of Liebknecht) believed Dreyfus to be innocent and as a result became quite negative towards Kraus and Die Fackel. Liebknecht himself died in 1900, shortly after submitting his last article to Kraus. Frank Field, The Last Days of Mankind: Karl Kraus and his Vienna (New York: St. Martin's Press, 1967), 42-46; Theobald, The Paper Ghetto, $73-4$.

${ }^{22}$ Wistrich, The Jews of Vienna, 512 ; Liebknecht's articles were published under the heading "Nachträgliches zur "Affaire". 
such a view of the "Jewish" campaign was not only shared by Liebknecht and Kraus, but also by Dreyfus himself. ${ }^{23}$

Liebknecht went to great lengths to show how the liberal press linked world Jewry to Dreyfus, and the resulting unfortunate absurdity of the outcome. The press also attacked any anti-Dreyfus argument, while at the same time glorifying Dreyfus's proponents. In explaining his views on the Dreyfus campaign, which Kraus ardently supported, Liebknecht wrote the following:

Urtheilen wir nach dem Erfolg. Ich bin gewiss kein Erfolgsanbeter, aber in praktischen Dingen ist der Erfolg doch oberster Richter. Was war der Erfolg der "Campagne"? Der Zweck war: 1. die Freispruchung des Hauptmanns Dreyfus zu bewirken; 2. dem Antisemitismus, der den Verrath eines Juden gegen die Juden ausbeutete, eine Niederlage zu bereiten. Und das Ergebnis?

Dreyfus ist zum zweitenmal verurtheilt, der Antisemitismus ist weit stärker als vor Beginn der Campagne. Es war ein kolossaler Missgriff, die Sache des Judenthums mit der Sache des Dreyfus eins zu erklären. Ist das Judenthums schuldig, wenn ein Jude das Verbrechen begangen hat? Kein vernünftiger Mensch in Frankreich und außerhalb Frankreich hätte daran gedacht, die Juden für Dreyfus verantwortlich zu machen. Die Folge der Identificierung des Judenthums mit Dreyfus musste sein, dass die zweite verurteilung des Dreyfus sich zu einer Niederlage des Judenthums gestaltet hat.

${ }^{23}$ Dreyfus came to this conclusion after he was exonerated and had become fully aware of the influence and implications of his trial. Theobald, The Paper Ghetto, 73. 
We judge by success. I am certainly no worshiper of success, but in practical things success is the ultimate judge. What was the success of the "campaign?" Its purpose was: 1. to bring about the acquittal of Captain Dreyfus; 2. to inflict a defeat on anti-Semitism, which was exploiting the betrayal of one Jew against all Jews. And the result?

Dreyfus has been judged [guilty] a second time, and anti-Semitism is stronger than it was before the campaign. It was a colossal misconception to identify the Jewish issue with the Dreyfus issue. Is Jewry guilty whenever a Jew has committed a crime? No reasonable person within France or outside of France would have thought that the Jews would be made responsible for Dreyfus. The consequence of the identification of Jewry with Dreyfus must be that the second judgment of Dreyfus turned into a defeat for Jewry itself. ${ }^{24}$

Kraus held similar views, but often focused his sentiments directly on the financial nature of the case for the presses, which he believed to be the real culprit. In satirizing the language of the press, which ranged from "rejoicing to the high heavens" (himmelhochjauzend) to "deathly depressed" (zutodebetrübt), Kraus reduced it to simply the "boom" (Hausse) and "bust" (Baisse) of the economy. ${ }^{25}$ Before the actual news about the second trial of Dreyfus, the following article appeared in the Neue Freie Presse. Kraus, seeing it as characteristic of the Neue

${ }^{24}$ Liebknecht, Die Fackel, edited by Karl Kraus, no.19, 6 (1899).

$$
{ }^{25} \text { Ibid, no } 16,24 \text { (1899). }
$$


Freie Presse's hypocrisy, published it verbatim in Die

Fackel, along with his judgment of its implications.

[from Neue Freie Presse] 'Das Interesse sämtlicher Plätze war heute ausschließlich durch die Frage beherrscht, welchen Ausgang der Process Dreyfus nehmen werde. In Berlin hatte die amtliche Erklärung des Reichsanzeigers einen günstigen Eindruck hervorgerufen und die Börse in feste stimmung versetzt. An der Wiener Börse lagen zahlreiche Verkaufsorders vor. Gegen halb 2 Uhr empfing ein hiesiges Bankinstitut aus Berlin eine Depesche des Inhalts, dass Frankfurt via Brüssel den Freispruch Dreyfus melde. Kurz vorher waren bereits Gerüchte über ein freisprechendes Urtheil verbreitet, welche eine lebhafte Bewegung und eine Courssteigerung der maßgebenden Speculationspapiere hervorriefen. Als gleichzeitig an verschiedene Institute und Privathäuser telephonische Gerüchte über ein freisprechendes Urtheil einlangten, entwickelte sich neuerlich ein reges Geschäft.' [Kraus] So lautet die Wahrheit über den Fall Dreyfus. ${ }^{26}$

[from Neue Freie Presse] The interest of all the markets was dominated exclusively today by the question of the outcome of the Dreyfus case. In Berlin, the official declaration in the Reichsanzeiger had produced a favorable impression, and opened the stock exchange in a stable mood. On the Viennese stock exchange, numerous transactions were made. Around 1:30, one of the banks here received a dispatch from Berlin saying that Frankfurt had heard via Brussels that Dreyfus had been acquitted. Shortly before this rumors of an acquittal had already been circulating and this had given rise to lively market activity and an increase in the exchange rate of the standard securities that had been speculating on this result. When telephone rumors of an acquittal arrived simultaneously in various institutes and private companies, there rapidly developed lively business activity.'

${ }^{26}$ Ibid, no. 16, 24 (1899). 
[Kraus] This is the real truth about the Dreyfus case.

Thus the Dreyfus Affair, for Kraus, reinforced the relationship between Jews and capitalism. It was simply another example of the exploitative activities in which the liberal newspapers, particularly the Neue Freie Presse, engaged to promote and further their own ends at the expense of both the Jews and western society as a whole.

\section{The Hilsner Affair}

\section{- Accusations of Jewish "Ritual Murder"}

Another major eruption of Austrian anti-Semitism occurred in 1899. The Deutsches Volksblatt, in connection with a "ritual murder" case in the little Czech town of Polna, had published an article attempting to revive the medieval anti-Jewish myth of ritual murder. The myth depicted Jewish use of the blood of Christians in the preparation of the Passover meals. It was taken for granted by any reasonable member of Viennese society that such tales were simply superstitious nonsense left over from medieval fear and suspicion of Jews. The blatantly anti-Semitic Deutsches Volksblatt revived the old idea in an attempt to sell issues in the atmosphere surrounding the 
trial of a Jewish man, Leopold Hilsner, accused of ritual murder.

The idea of ritual murder was not new, and in fact there had been several accusations of ritual murder in the Bohemian provinces during the 1890s. The myth of ritual murder, also known as "blood libel," claimed that Jews needed the blood of a Christian, preferably that of a young virgin, in order to make the unleavened bread used in the celebration of Passover. According to the myth, the victim's blood was obtained in a ritualistic manner, following the rules by which Jews slaughtered animals to meet the Kashrut or kosher dietary laws. ${ }^{27}$

As a result of the crises of national identity, Erenetic nationalism, and tensions between ethnic as well as religious groups throughout Europe, fourteen ritual murder cases were recorded during the 1890 s in east and

${ }^{27}$ Encyclopaedia Judaica, vol. IV (Jerusalem, 1971), 1120-1131 ; Červinka Frantisěk, "The Hilsner Affair," in Leo Baeck Institute Year Book XIII (1968) : 142-157 ; Alan Dundes, ed., The Blood Libel Legend: A Casebook in AntiSemitic Folklore (Madison and London: University of Wisconsin Press, 1991) ; Jonathan Frankel, The Damascus Affair: "Ritual Murder," Politics and the Jews in 1840 (Cambridge University Press, 1997) ; Steven Beller, "The Hilsner Affair: Nationalism, Anti-Semitism, and the Individual in the Habsburg Monarchy at the Turn of the Century," in Robert B. Pynsent, ed., T. G. Masaryk (18501937), Volume 2 Thinker and Critic (New York: St. Martin's Press, 1989). 
central Europe. ${ }^{28}$ Other well-known ritual murder cases during the nineteenth-century were the Beilis trial in Kiev in 1913; the Konitz case in 1900 and the case of Xanten in 1891, both in Prussia; the Tisza-Eszlar case in Hungary in 1882, and the Damascus Affair in Syria in $1840 .{ }^{29}$ There was also a ritual murder case in Velizh, Russia, which lasted from 1823 to 1835. This case, however, did not receive international attention at the time. ${ }^{30}$

In light of this sort of widespread superstitious mentality, it was relatively easy to promote the idea of a

${ }^{28}$ It is important to note that France did not experience the same sort of anti-Semitic riots and accusations of "ritual murder" as the rest of Europe. This anomaly can be partially explained through the lack of a continuous Jewish community in France after the medieval expulsion of the Jews. Additionally, the Jews were granted emancipation during the French Revolution and became acculturated and for the most part assimilated in the liberal atmosphere of France. This assimilation was aided in large measure by the small number of Jews in France (approximately 80,000 Jews in a population of over 40 million). However, anti-Jewish attitudes and anti-Semitic hatred was expressed during the Dreyfus Affair, which could be seen as the climax of a latent anti-Jewish sentiment in France that was not manifested in other ways. Frankel, The Damascus Affair, 423 ; Jacob Katz, From Prejudice to Destruction: Anti-Semitism, 1700-1933 (Cambridge: Harvard University Press, 1980) ; Wistrich, Between Redemption and Perdition.

${ }^{29}$ Frankel, The Damascus Affair, 4, 423.

${ }^{30}$ Dundes, ed., The Blood Libel Legend, 136-161, 180-196; Frankel, The Damascus Affair, 423. 
"ritual murder" among the czech population when the body of nineteen year old Anežka Hrůzová, was discovered on April 1, 1899, near the town of Polna. ${ }^{31}$ The main suspect in the initial investigation was a Jewish man, Leopold Hilsner, who had a history of petty theft. ${ }^{32}$ Hilsner had supposedly been seen in the area shortly before the murder had allegedly taken place. He and two unknown Jewish accomplices were implicated in the murder.

In the absence of a significant amount of blood and the lack of evidence for a sexual or monetary motive, the accusation of ritual murder was quickly leveled at Hilsner by the anti-Semitic press. Although no direct mention of "ritual murder" or "blood libel" was made at the trial, the prosecuting attorney's closing remarks claimed that "disgusting people, people of another race, people who have acted like animals, have murdered a virtuous Christian

${ }^{31}$ Polna was in a German-speaking area on the border between Bohemia and Moravia. There were approximately 5,000 inhabitants, of which 212 were Jews. In the antiSemitic atmosphere during and after the Hilsner Trial, many Jews emigrated elsewhere. Today, there are no Jews living in Polna. Červinka, "The Hilsner Affair," 146.

${ }^{32} \mathrm{Hilsner}$ was the stereotypical "poor Jew." He had no fixed income and was described as "a man of low morals, an idler and vagabond who allowed himself to be maintained by his mother, a poor widow who herself depended on alms from other Jews." Ibid. 
virgin so that they could use her blood...for what purpose this race, or sect, need this blood, that this trial has not brought to light." ${ }^{33}$

Hilsner was found guilty on september 16, 1899, and sentenced to death by hanging. His trial sparked debate around the world as Jews themselves were now accused of practicing ritual murder. ${ }^{34}$ After much public outcry and publicity from both anti-Semitic presses and liberal papers defending the Jews, Hilsner was tried a second time in October, 1900. He was found guilty again, but this time sentenced to life in prison. He was later pardoned by Emperor Karl I of Austria in 1916 and lived under the name of Heller traveling between Prague and Vienna. Hilsner died in 1928 at the age of $59 .{ }^{35}$

Tomáš Garrigue Masaryk, a Czech nationalist hero, philosopher, and first president of Czechoslovakia (1918-

${ }^{33}$ Die Neue Freie Press, 16 September 1899, 2 ; quoted in Beller, "The Hilsner Affair," 53.

${ }^{34}$ Červinka, "The Hilsner Affair," 148 ; Beller, "The Hilsner Affair," 53.

${ }^{35}$ The true identity of the murderer was never discovered; and this only fueled further speculation and rumor. Frantisěk Červinka has Hilsner pardoned in 1918, not 1916. The earlier date is from Beller, taken from Encyclopaedia Judaica, vol. III, 46. Červinka, "The Hilsner Affair," 149, 154 ; Beller, "The Hilsner Affair," 55. 
1935), joined in the campaign to dissociate the accusations of ritual murder from the Hilsner case. Masaryk, who grew up surrounded by anti-Semitism and tales of ritual murder, sought "not to defend Hilsner, but rather to defend Christians from superstition." ${ }^{36}$ Masaryk sought to prevent the Hilsner trial from becoming an "Austrian Dreyfus Affair." 37 He also was reacting to his belief that "the mass of Czech readers does not inquire about their [anti-

${ }^{36}$ Beller, "The Hilsner Affair," 56.

${ }^{37}$ In addressing the jury at the Hilsner Trial, the Public Prosecutor cautioned them with the following statements which attest to the large amount of attention that the trail was receiving: "A certain Czech newspaper has referred to the Polna murder as the Austrian Dreyfus affair. It is true that the press printed daily reports several columns long, during the Dreyfus trail, and in the same way the Polna murder has filled both home and foreign newspapers. Two parties [the anti-Semitic press and the Liberal press] opposed to each other have chosen this case in order to clash on the battlefield of the press. Everyone knows them, it is not necessary to name them. Immediately after the discovery of the body of the unfortunate Anežka Hrůzová, the papers of both sides published long articles, raising first of all the question of what might be the motive of this mysterious case.

Esteemed gentlemen, do not let this controversy confuse you. Even if one or the other of the parties publishes long articles, this must not influence your verdict. You must only consider the evidence and decide whether it is to the advantage or detriment of the accused. The motive is of secondary importance." (my emphasis) Červinka, "The Hilsner Affair," 147. 
Semites] sources and data, but blindly believes anything that incriminates the Jews." ${ }^{38}$

During the course of his investigation, Masaryk came to believe that much of the evidence had been misinterpreted or ignored, evidence which ruled out the possibility of a "ritual" murder. Through the use of forensic methods, Masaryk established that the girl had most likely been killed elsewhere and her body moved to the location where it was found. This would account for the small amount of blood found at the scene. Additionally, the girl's throat appeared to have been stabbed, not slit across the neck as a "ritual" murder would have required. The most obvious fact, which was completely ignored at Hilser's first trial, was that the date on which the murder was believed to have occurred was after the Jewish holiday, thereby negating the need for any blood for ritual purposes. ${ }^{39}$

Masaryk was widely criticized for his "debunking" the idea of ritual murder as a motive for Hilsner's crime. In response, he published a letter in the Neue Freie Presse,

${ }^{38}$ Ibid, 149.

${ }^{39} \mathrm{~A}$ summary of Masaryk's findings was published in the Neue Freie Presse, 10 November 1899, 2 ; Beller, "The Hilsner Affair," 54 . 
in which he claimed that the use of ritual murder propaganda in the Hilsner trial was simply "a way of characterizing Jews as economic vampires."40 Masaryk asserted that anti-Semitism only clouded the issue and promoted a mob mentality in response to a lack of political power. The anti-Semitic consequences of the Hilsner trial were felt sharply in Vienna. In september 1899, an antiSemitic meeting was held in the city with Mayor Karl Lueger in attendance. Speeches were given on both Dreyfus and Hilsner and presented the Jews as an international, "interconnected power that could destroy states." ${ }^{41}$ Jewish mysticism and "Jewish" solidarity also became hot issues; one allusion was made to the Hilsner trial and a pervasive fear of the Jews was evident in the feeling that "they have set their foot on our necks; perhaps they want our blood as well." ${ }^{42}$

In light of all the attention surrounding the Hilsner Affair, Kraus was quick to attack the liberal press's coverage of the incident. Kraus did not attack the

${ }^{40}$ Beller, "The Hilsner Affiar," 57.

${ }^{41}$ The basic events of the meeting were reported in the Neue Freie Presse, 28 September 1899, 7 ; Beller, "The Hilsner Affair," 60 .

${ }^{42}$ Ibid. 
Deutsches Volksblatt, as he did not believe that such accusations would be taken seriously. However, when the Jews of Vienna organized a mass movement to reject the accusation of ritual murder and to support Hilsner, Kraus quickly reacted with the following:

Das Deutsche Volksblatt hat die Frage aufgeworfen, ob die Juden sich zu ihrem Osterfeste christlichen Blutes zu bedienen pflegen, und dreitausend Juden unter Führung des Herrn Güdemann stürmen den Musikvereinssaal, um mit einem überzeugten "Nein!" zu antworten. Das klingt zwar wie eine Absage, aber es bedeutet dazu, dass die Juden auf ein vom Feinde abgestecktes Terrain mit imponierender Bereitwilligkeit gefolgt sind. ${ }^{43}$

The Deutsche Volksblatt has raised the question as to whether the Jews customarily serve Christian blood with their Easter festivals, and three thousand Jews under the leadership of Herr Güdemann have stormed the Musikvereinssaal and replied with a forceful "NO!". This sounds like a rejection, but it actually means that the Jews have blundered with enthusiasm upon a terrain cluttered with enemies.

For Kraus, the anti-Semitic press was so crude and ridiculous that even the most naive reader should be able to perceive the inherent contradictions in their publications. For him, the actions of the liberal press drew attention to the Jews and served to validate the claims of the anti-Semites by supporting and encouraging a

${ }^{43}$ Kraus, Die Fackel, no. 19, 24 (1899) ; Theobald, The Paper Ghetto, 69. 
"Jewish" community and Jewish solidarity in the face of hostility. The action of three thousand Jews speaking out against the anti-Semitic press did more to promote popular anti-Semitism than the actual events themselves.

Kraus reacted to the Hilsner Affair in much the same way as he did to the Dreyfus Affair. He believed both men were guilty, but that these cases were made "Jewish" by the anti-Semitic and liberal presses. Both of these groups, in his mind, consciously played off one another in order to promote public hysteria and sell papers. Thus he could claim:

Herr Güdemann vergisst, dass die vernünftigen Christen, wenn sie auch Instinkt und Erziehung bestimmen mag, die Neue Freie Presse und die von ihr gepredigte Finanzmoral zu verachten, darum noch lange nicht ihre Lebensanschauung nach den Plänen des Deutschen Volksblatt und seiner Ritualmorderbuben gezimmert haben. Es ist durchaus nicht notwendig, dass irgend jemand außer den geschäftlich am Blutmärchen Betheiligten zu dieser Frage Stellung nimmt. ${ }^{44}$

Herr Güdemann forgets that reasonable Christians, insofar as their instincts and education make them despise the Neue Freie Presse and the financial morality it preaches, are still far from constructing their lives' world view according to the plan of the Deutschen Volksblatt and its ritual murder boys. It is completely unnecessary that anyone except those professionally involved in the "Blood fairy tale" take a position on this question.

${ }^{44}$ Kraus, Die Fackel, no. 19, 24 (1899); Theobald, The Paper Ghetto, 70-71. 
For Kraus, the Hilsner Affair echoed the Dreyfus Affair in that both men were probably guilty, but that all of world Jewry had been forced to stand alongside them because of the assertions of the liberal press. With both men convicted not once but twice, the suspicion of a "Jewish conspiracy" and fear of Jews was reinforced and strengthened immeasurably. With Hilsner, the myth of ritual murder was revived and made legitimate by the very campaign against it.

Kraus's reactions must be viewed in light of his environment. As an intellectual, he had no positive associations to make with Judaism. Non-Jewish intellectuals looked down upon Jews in general, and every effort was made on the part of acculturated Jews to fit in with the expectations of "high society." By adopting conservative definitions of Jews and anti-Semitism, Kraus in some ways mimicked the prejudices he was subjected to in Vienna. This illustrates Kraus's conception of the nonJewish culture to which he was aspiring, and the contradictory actions of acculturated liberal Jews that, in his mind, were supporting and encouraging anti-semitism. 


\section{"Zivilisation" versus "Kultur"}

The term "civilization" can connote a wide variety of social creations. It can refer to a given society's level of technological development or scientific knowledge, its religious ideas or customs, its forms of judicial punishment, various types of mannerisms, male-female relations, dwellings, foods, and culinary habits. However, the typical concept of "civilization" is a peculiarly occidental development. Western societies have traditionally used "civilization" to define themselves and their "natural" superiority over other groups. ${ }^{45}$

According to the sociologist Norbert Elias, the English and the French have traditionally seen civilization as the measure of their own nations and the significance of the progress of the west. For Germans, Zivilisation is of similar importance, but is arguably of a secondary concern. Zivilisation, in German, is primarily the outward expression of humanity. The ideal for describing German

${ }^{45}$ Norbert Elias, The Civilizing Process: Sociogenic and Psychogenic Investigations, translated by Edmund Jephcott, edited by Eric Dunning, Johan Goudsblom, and Stephen Mennell (Oxford: Blackwell Publishers, 2000), 5. 
pride in their achievements and themselves is better expressed in the term "Kultur." ${ }^{46}$

Whereas the English and French concept of "civilization" can perhaps denote technological, political, economical, moral, religious, or social facts, the German usage of Kultur refers "essentially to intellectual, artistic, and religious facts, and has a tendency to draw a sharp dividing line between facts of this sort, on one side, and political, economic, and social facts on the other."47 English and French usage of "civilization" refers equally to accomplishments and the attitudes or behaviors of people. German Kultur, however, cannot reflect the innate value of an individual in the absence of other accomplishments. The German adjective kulturell, a derivative of Kultur, describes "the value and character of particular human products rather than the intrinsic value of a person." 48

The disparate nature of Kultur is more significant for identifying the intellectual polemic that the German intellectuals reflected. While zivilization acts to limit

\footnotetext{
${ }^{46}$ Elias, The Civilizing Process, 5-6.

${ }^{47}$ Ibid, 6.

${ }^{48}$ Ibid.
} 
differences in nationalities and social groups, Kultur "places a special stress on national differences and the particular identity of groups." ${ }^{49}$ For Elias, this distinction between "civilization" and "Kultur" is a result of the clear conception and unified identity of "French" and "English" as compared with the German. The French and English had a sense of security in their identities that drew strength from the relative stability of their national boundaries and the long histories of their independent societies. The Germans, however, established an independent nation comparatively late in European history. The perennial question "Who or what is German?" has never been satisfactorily resolved. As a result, German Kultur has continually been used - often unscrupulously - to reaffirm German national pride and the distinctiveness of the German people. ${ }^{50}$

According to Elias, the antithesis of "Zivilization" and "Kultur" became crystallized during the eighteenthcentury in the polemics of the German middle class intelligentsia. These intellectuals were responding to the external, superficial "courtly" mannerisms of the upper

$$
\begin{aligned}
& { }^{49} \text { Ibid, } 7 . \\
& { }^{50} \text { Ibid, } 7 .
\end{aligned}
$$


classes. These aristocratic elites did not "produce" in the same sense as the intellectuals and others who aspire towards the ideals embodied in Kultur. The distinction between accomplishment-oriented Kultur and the superficial and aesthetic nature of zivilisation became clear in the minds of eighteenth century German philosophers such as Immanuel Kant. ${ }^{51}$

This distinction was further enhanced by an elite German aristocracy who paid homage to the French and attempted to distance themselves from "middle class" or "bourgeois" society through their use of French language, political ideas, dress, and mannerisms. As a result, the politically isolated German middle class developed an intellectual model of the German ideal, building on the idea of Kultur, which was separated from the political realm. Elias has shown that throughout the late eighteenth-century, a distinct class dichotomy existed. On one side, a French-speaking German nobility held political power, while a German-speaking intelligentsia sought to honor their German heritage and create a German ideal of intellectual thought and literary exploration. It was this

${ }^{51}$ Ibid, $10-11$. 
second group who crystallized Kultur in its opposition to Zivilisation. 52

The German middle class gradually rose from a secondrank status, to the exponent of German national consciousness, and finally to a politically influential ruling class. They achieved this transformation by contrasting themselves with the "Frenchified" aristocratic elite. The national identity inherent in Kultur was now modified from one of social distinction into a national orientation: German "Kultur" against French "Civilité."

In nineteenth and early twentieth century Viennese society, acculturated Jews such as Karl Kraus attempted to assimilate into Austro-German Kultur through the process of Bildung, the acquisition of Kultur through extensive education (often referred to as a "civilizing education"). 53 This process of education would help lead an individual from a backward, medieval superstition and prejudice towards enlightenment. Bildung also offered the opportunity to transcend religious differences between Jews

${ }^{52}$ Ibid, 9-15, 24-26.

53 "The word Bildung combines the meaning carried by the English word 'education' with notions of character formation and moral education." Georege I. Mosse, German Jews Beyond Judaism (Bloomington: Indian University Press, 1985), 3, 1-20. 
and non-Jews through a shared moral and cultural ideal, at least in its early manifestations. By the end of the nineteenth century, the concept of Bildung for Jews was linked to overcoming their own Jewishness, while "most Germans themselves had distorted the original concept beyond recognition" by adding romantic and nationalistic elements. ${ }^{54}$ Under these influences, the concept of Bildung was corrupted and applied to a bourgeois class materialism that directly contradicted the early individualistic goal of self-improvement and advancement.

With this new model of Bildung, educational training for Jews often led to professional careers as doctors, lawyers, teachers, and journalists. Steven Beller has compiled the following statistics for Jewish professionals during the late nineteenth and early twentieth-centuries. ${ }^{55}$ 47.4 percent of Viennese doctors in 1880 were of Jewish heritage, compared with 61 percent in 1881, 50 percent in 1930, and 47 percent in 1936. Jewish lawyers made up 57.9 percent of that profession in 1890, and 62 percent in 1936 . At the University of Vienna, Jewish professors represented 34 percent of all professors in 1910. They were primarily

${ }^{54}$ Ibid, 4-7. 
concentrated in law (24 percent), medicine (51 percent), and philosophy (22 percent). In journalism, Jews comprised between 51.5 and 63.2 percent of the editors, correspondents, and contributors for all the major newspapers in Vienna - not including periodicals or pamphlets - in 1909. Anti-Semitism blocked the path toward a "patriotic" form of assimilation, so many Jews turned to Bildung as a way to immerse themselves in German Kultur so that "true" acceptance into society might gradually be attained in the future. ${ }^{55}$

\section{Kraus's hope for Judaism and Humanity}

Still responding to the cultural milieu in which he found comfort, Kraus blamed the decline of Austro-German society on the intellectuals who forced German Kultur to serve debased Zivilisation. This "civilization" then served capitalist-commercial ends, completely subverting

${ }^{55}$ Steven Beller, Vienna and the Jews, 1867-1938 (Cambridge: Cambridge University Press, 1989), 33-39, 1430 .

${ }^{56} \mathrm{Helmut}$ Gruber, "Red Vienna and the "Jewish Question"," in Leo Baeck Institute Year Book XXXVIII (1993) : 104-105. George L. Mosse, German Jews Beyond Judaism (Bloomington: Indian University Press, 1985) ; idem, Germans and Jews: The Right, the Left, and the Search for a "Third Way" in pre-Nazi Germany (New York: Howard Fertig, 1970). 
the Enlightenment goal of individual happiness and virtue. For Kraus, the failed assimilation of the Jews only exacerbated the problem on two fronts: Jews were viewed as the primary producers of high culture in Vienna and also as the primary agents of materialist-capitalism. By liberating Jews from this debased "Frenchified" culture and exposing those Jewish and non-Jewish elements that were working against humanity and German Kultur, Kraus hoped to solve the "Jewish Question" and set western civilization back on its proper course.

The liberal "Jewish" newspapers, particularly the Neue Freie Presse, became for Kraus the incarnation of all the evils and corruption of Austrian society and of the bourgeois-materialist Zivilisation that he detested. Kraus saw the implicit danger in the combination of highly developed press technology and the equally developed shamelessness of the journalists themselves (die entwickelte Tecknik und die entwickelte Schamlosigkeit).$^{57}$ Rather than debate lofty philosophical issues, Kraus instead focused on the readily quantifiable issues around him that he hoped to change through his satire. By exposing the hypocrisies of and abuses by the press, Kraus

\footnotetext{
${ }^{57}$ Kraus, Die Fackel, nos. 368-369, 47.
} 
hoped to undermine its extensive influence in society. In attacking politicians and legislation, Kraus hoped to promote the equality espoused, but never implemented, by the government. Kraus believed that the Neue Freie Presse forced the subordination of Kultur to Zivilisation and promoted economic chaos through financial speculation and bad investment advice. To prove the lack of intellectual depth of the Neue Freie Presse, Kraus often submitted anonymous articles of complete nonsense written in a dense academic form. These articles were published in complete ignorance on the part of the editors. ${ }^{58}$ Despite these gross oversights, the Neue Freie Presse could control the mass reading public. Its crude sensationalism could condemn or exonerate major social and political issues and figures, such as the coverage of the Dreyfus Affair and the "ritual murder" trial of Leopold Hilsner, in the eyes of the

${ }^{58}$ One of Kraus's more famous exploits was an article describing an earthquake from the perspective of a mining engineer. "It included fictitious distinctions between "cosmic" and "telluric" tremors, and in the course of his description, the mythical engineer related how the mysterious Grubenhund beast became restless and began to bellow." Grubenhund is a Krausian play on words, since it is the beast "causing" the earthquakes and yet is also a type of cart used to haul ore from mines. Allan Janik, and Stephen Toulmin, Wittgenstein's Vienna (New York: Simon and Schuster, 1973) 88-89. 
public, and create the mass hysteria necessary to catapult a nation into war. ${ }^{59}$

Drawing upon John Theobald's formulation, Kraus's solution was to become "an exceptional Jew who overcame his Jewishness," thus transcending man's inhumanity to man and the corruption of "Zivilisation," or so he believed. ${ }^{60}$ Kraus believed that the Jews were capable of assimilation, but only if they would sacrifice the external differences and customs that separated them from Austrian society. According to Kraus, "the unshakable faith in the adaptability of the Jewish character is the best orthodoxy: just once may this faith become the faith of the [our] fathers" (Der unumstössliche Glaube an die Anpassungsfähigkeit des jüdischen Charakters ist die beste

${ }^{59}$ Kraus, Die Fackel, (May 1899) ; Wistrich, The Jews of Vienna in the Age of Franz Joseph, 510-11; Wilma Abeles Iggers, Karl Kraus: A Viennese Critic of the Twentieth Century (The Hauge: Martinus Nijhoff, 1967), 107-109; Theobald, The Paper Ghetto, 64-65, 71-72.

${ }^{60}$ Theobald, The Paper Ghetto, 57. Leopold Liegler also praised Kraus for "overcoming" his own Jewishness. Liegler claimed that "in all periods individual Jews have managed to neutralize the semitic poison within themselves, which has been so harmful to the western spirit, and to develop voluntarily a free, ethical humanitarianism beyond a strictly circumscribed ethnicity." Leopold Liegler, Karl Kraus und sein Werk (Vienna: Richard Lanyi, 1920), 47 ; quoted in Zohn, Karl Kraus and the Critics, 20. 
Orthodoxie: man lasse ihn nur erst einmal den - Glauben der Väter werden) ${ }^{61}$

With this perception of the "Jewish Question," the solution for Kraus became a personal matter. A Jew would have to renounce Judaism and purge himself of the very characteristics that Kraus saw as provoking anti-semitic reactions and contributing to modern decadence of "Zivilization." Only then could Jews assimilate completely into the early nineteenth-century ideal envisioned by Kraus. The current "corrupt" era was in a precipitous decline that could only be reversed, in Kraus's mind, by purging the immoral and materialistic interests of western society and returning to an Enlightenment model of liberalism. ${ }^{62}$ Kraus did not place the blame for this corruption solely on the Jews, but he did attempt to expose the elements, particularly Jewish ones, which were

${ }^{61}$ Kraus, "Eine Krone für Zion,", 309. This is in direct contrast with the views of the Zionists, who rejected the idea of Jewish adaptation to Austro-German society. In actuality, the goal of complete assimilation was something that the younger and older generations shared. Both groups recognized that anti-Semitism was responsible for the continuation of a specifically "Jewish" identity, and both groups believed that assimilation was possible, thus maintaining the "faith" in adaptability that Kraus is suggesting. Beller, Vienna and the Jews, 210 ; Rozenbilt, The Jews of Vienna, 4-12, 124-125.

${ }^{62}$ Beller, Vienna and the Jews, 211. 
contributing to the decline of Europe. However, by identifying and legitimizing the "anti-Semitic producing" qualities of the Jews, Kraus was also accepting and validating one of the major assertions of the anti-Semites: that the Jews were to blame for anti-Semitism. 


\title{
Chapter V: Conclusion: The Last Days of Mankind
}

\author{
"My readers think that I write for the day because my \\ writings are based on the day. So I shall have to wait \\ until my writings are obsolete. Then they may acquire \\ timeliness." 1 \\ "How is the world ruled and led to war? Diplomats lie to \\ journalists, then believe those lies when they see them in \\ print." ${ }^{2}$ \\ "Nothing is more horrible than myself in the mirror of \\ hysteria. Nothing is more vulgar than my style in the \\ hands of another. To imitate me is to punish me." 3 \\ "The development of technology will leave only one problem: \\ the infirmity of human nature." ${ }^{4}$
}

There was something supremely optimistic about the 1iberal, educated, and acculturated Jews in Austria and Germany during the late nineteenth and early twentieth centuries that gave them the false assumption that the parties with which they dealt, the societies in which they lived, and the culture in which they participated were both liberal and rational and shared the same general worldview as themselves. These logical, peaceful, and benevolent Jews, who believed themselves to be protected under the

\section{${ }^{1}$ Karl Kraus, Half-Truths and one and a Half Truths:} Karl Kraus, Selected Aphorisms, edited and translated by Harry Zohn (Montreal: Engendra Press, 1976), 34.

$$
\begin{aligned}
& { }^{2} \text { Ibid, } 81 . \\
& { }^{3} \text { Ibid, } 38 . \\
& { }^{4} \text { Ibid, } 123 .
\end{aligned}
$$


shield of a failing liberalism, suffered from the assumption that those groups who were against them would attempt to reach some sort of compromise along basic liberal, democratic, and humanitarian guidelines. This attitude prevailed among the assimilated Jews of Austria and Germany from the years following their emancipation from the ghettoes in 1867 to the Anschluß toward the end of the 1930s. It was only after the unbelievable horrors of Hitler and the Nazi party were discovered that the true dangerous and dire potential of their situation became clear.

\section{Kraus's Evolution-}

\section{The Expiration of the Word}

As anti-Semitism grew ever more violent and the political system in Austria and Germany became increasingly reactionary, Kraus modified his stance toward Jews and their "hidden" language in the late 1920s and early 1930s. In response to the radicalization and rabid nationalism of the conservative parties during the 1920s, Kraus shifted from political isolation towards the Social Democratic 
party. ${ }^{5}$ With the rise of the Nazis, the perversion of language by non-Jews reached new heights. Kraus continued to attack what he regarded as the corruption of language, but he no longer considered it a peculiarly "Jewish" threat. Instead it was further evidence of the success of "Zivilization," through the actions of the Jews and other corruptive elements, over German "Kultur."

The utter depravity of the Nazi propagandists was far worse than the aesthetic and cultural offenses of the liberal press. The Nazi slogans transcended the figurative and metaphorical language of the previous era transforming word into deed. Words, no longer the precise tools of rhetoric, became the instruments for mobilizing an unthinking populace against specific groups and encourage an intense hatred of the Jews.

Kraus's last major work, Die Dritte Walpurgisnacht, was written in the summer of 1933. Some selections of it were published in issues of Die Fackel, but Kraus chose at the last minute not to publish it in its entirety, out of a fear that it would motivate the Nazis to commit further

${ }^{5}$ Edward Timms, Karl Kraus, Apocalyptic Satirist: Culture and Catastrophe in Habsburg Vienna (New Haven: Yale University Press, 1986), 360-362. 
acts of violence. ${ }^{6}$ In this final work, Kraus predicted and prophesied many of the horrors to come with the Nazis after Anschluß. What most concerned him was the complete subjugation of language to actions, to the point that the power and purity of language was lost:

Wenn diese Politiker der Gewalt noch davon sprechen, daß dem Gegner "das Messer an die Kehle zu setzen", "der Mund zu stopfen" sei, oder "die Faust zu zeigen" ; wenn sie überall "mit harter Faust durchgreifen" wollen oder mit "Aktionen auf eigene Faust" drohen: so bleibt nur erstaunlich, daß sie noch Redensarten gebrauchen, die sie nicht mehr machen. Die Regierung, die "mit aller Brutalität jeden niederschlagen will, der sich ihr entgegenstellt" - tut es. "Ausstoßen aus der Deutschen Arbeitsfront "läßt das Brachium erkennen, mit dem deren Machthaber an einer Kehlkopfverletzung beteiligt war; und vollends erfolgt die Absage an das Bildliche in dem Versprechen eines staatspräsidenten:

Wir sagen nicht: Auge um Auge, Zahn um Zahn, nein, wer uns ein Auge ausschlägt, dem werden wir den Kopf abschlagen, und wer uns einen Zahn ausschlägt, dem werden wir den Kiefer einschlagen.

Es geschieht aber auch ohne die Vorbedingung. Und diese Revindikation des Phraseninhalts geht durch alle Wendungen, in denen ein ursprünglich blutiger oder handgreiflicher Inhalt sich längst zum Sinn einer geistigen offensive abgeklärt hat. Keine noch so raffinierte spielart könnte sich dem Prozeß entziehen - selbst nicht das entsetzliche: "Salz in offene wunden streuen". Einmal mußs es geschehen sein, aber man hatte es

${ }^{6}$ Karl Kraus, Die Dritte Walpurgisnacht, edited by Heinrich Fischer, (Munich: Kösel-Verlag, 1952), 308, 310 ; Sidney Rosenfeld, "Karl Kraus: The Future of a Legacy" Midstream (April 1974) : 76. 
vergessen bis zum Verzicht auf jede Vorstellung eines Tätlichen, bis zur völligen Unmöglichkeit des Bewußtwerdens. Man wandte es an, um die grausame Erinnerung an einen Verlust, die Berührung eines Seelenleids zu bezeichnen: das gibt's immer; die Handlung, von der's bezogen war, bleib ungedacht. Hier ist sie:

Als sich der alte Genosse beim Kartoffelschälen einen tiefen Schnitt in die Hand zufügte, zwang ihn eine hohnlachende Gesellschaft von Nazi, die stark. blutende Hand in eine Sack mit Salz hineinzuhalten. Das Jammergeschrei des alten Mannes machte ihnen großen spaß.

Es bleibt unvorstellbar; doch das es geschah, ist das Wort nicht mehr brauchbar....Es war eine Metapher gewesen.?

Whenever these politicians of violence still talk of their opponents with "holding a knife to their throats", "stuffing their mouths", or "shaking a fist"; whenever they constantly take "drastic measures with hard fists" or threaten with "action on one's own initiative": it remains only surprising that they still use phrases, which they no longer create. The government that "wants to beat down with all brutality anyone who opposes it" - does it." Expelled from the Deutschen Arbeitsfront "enables us to recognize the organ/wing by which its leaders participated in a throttling, quieting the opposition, and ultimately there follows the rejection of the figurative in the promises of the Federal President:

We do not say: an eye for an eye, tooth for a tooth, no, whoever pokes out one of our eyes, we will cut off his head, and whoever knocks out one of our teeth, we will smash in his jaw.

It is happening, but even without the prerequisite. And this re-vindication of the

${ }^{7}$ Kraus, Die Dritte Walpurgisnacht, 122-124. 
meaning of the phrases runs through all turns of phrase in which an originally bloody or violent meaning has been long detached from the sense of a spiritual offense. Not even the still refined play on words could escape this process - not even the horrific "to pour salt into open wounds." Once it must have happened, but one had forgotten it to the point of the renunciation of any idea of violence, to the point of complete impossibility of conscious comprehension. One used it in order to designate the terrible memory of a loss, the touch of soulful sorrow: it has always been so; the behavior from which it had derived remains in the subconscious. Here it is:

When the old inmate peeling potatoes made a deep cut in his hand, a jeering group of Nazis forced him to stick his heavily bleeding hand in a sack of salt. The miserable screams of the old man were great fun for them. ${ }^{8}$

It remains inconceivable, but it happened nevertheless; the word is no longer useful... it had become a metaphor.

In referring to the rise of the Nazis and the complete inability to polemicize against them, Kraus concluded in 1936 that "the word expired when that world awoke" (das Wort entschlief, als jene welt erwachte). ${ }^{9}$ Kraus's

\footnotetext{
${ }^{8}$ Sidney Rosenfeld asserts that Kraus is quoting this description from a report from a concentration camp. (Rosenfeld, "Karl Kraus," 76-77.) This is not stated as such in Kraus's work. However, Kraus does make frequent allusions and references to "Dachau" and "Kozentrationslager"; it is evident that he was aware of their existence while writing this work in 1933.

'This was the final line from Kraus's last poem. Karl Kraus, In These Great Times: A Karl Kraus Reader, edited by Harry Zohn, translated by Joesph Farby, Max Knight, Karl F. Ross, and Harry Zohn (Montreal: Engendra Press, 1976), 259 .
} 
satirical style consisted of using direct quotations from his opponents to uncover their true nature. With the Nazis, however, Kraus realized that the reason and logic of language had been lost. He spoke a language completely different from the mindless hatred of Hitler and the Nazi propagandists. Kraus fought tirelessly to revive the "life-less" body of Austria, but in the end, he knew that it was over. Thus, as Berthold Brecht said of Kraus, "when the age came to die by its own hand, he was that hand."10 For Kraus, westernized Jewry was one of the major contributors to the decline of Europe. This decline afflicted all of Europe and was the result of humanity's drive for technological advances combined with moral, intellectual, and spiritual apathy.

Das Um und Auf meiner politischen Gesinnung besteht darin, daß ich diesem aller Männerlichkeit abtrünnigen und allen Glauben zu sich herabzweifelnden Wesen den Ruin der Welt und des staates im besondern zuschreibe, diese Staates, der in Wahrheit der Exponent aller Unruhe ist und allen femininen Verfalls. ${ }^{11}$

The end-all and be-all of my political convictions is that I attribute the ruin of the

${ }^{10}$ Walter Benjamin, Illuminationen (Frankfurt am Main: Suhrkamp Verlag, 1961), 388.

${ }^{11}$ Karl Kraus, "Er ist doch e Jud," in Untergang der Welt durch schwarze Magie, ed. by Heinrich Fischer, (Munich: Kösel-Verlag, 1960), 335. 
world and of the state in particular to all those who are unfaithful to humanity [the Jewish press] and who doubt all beliefs; or this state which in truth is the exponent of all unrest and all effeminate decline [echoing the alleged link between Jews and femininity]. ${ }^{12}$

\section{Karl Kraus and the "Third Force"}

George L. Mosse has analyzed what he termed the "Third Force" in German society in the first decades of the twentieth century. ${ }^{13}$ In this view, the left-wing intellectuals as well as right-wing nationalists retreated from the realm of normal politics and class struggle and into a world comprised of ideologies. Despite their many differences, both groups were responding to their dissatisfaction with the new "modern" world, and rejected this modernity in favor of more radical pursuits. ${ }^{14}$

${ }^{12}$ For discussions on the links between Jews and Femininity, see Sander Gilman, Jewish Self-Hatred: AntiSemitism and the Hidden Language of the Jews (Baltimore: Johns Hopkins University Press, 1986) ; idem, The Jew's Body (New York: Routledge, 1991); Nancy Harrowitz and Barbara Hyams, eds., Jews and Gender: Responses to otto Weininger (Philidelphia: Temple University Press, 1995); Marc Weiner, Richard Wagner and the Anti-Semitic Imagination (Lincoln: University of Nebraska Press, 1997).

${ }^{13}$ George L. Mosse, Germans and Jews: The Right, the Left, and the search for a "Third Way" in pre-Nazi Germany (New York: Howard Fertig, 1970).

${ }^{14}$ Ibid, $4-5$. 
For Mosse, these men had little desire to change society, but instead sought solace in the aesthetic realms of art, literature, language, and music. They became "obsessed with the importance of absolute values and opposed the 'hypocrisy' of political tactics and compromise."15 These proponents of this "third force" were reacting to the very recent past, which they evoked in varying incarnations depending on their perspective. The pan-German nationalists were distancing themselves from the absolute worship of military values and the omnipotence of the state. The socialists and others of the left wing rejected the hard-line Marxism that had thus far failed to provoke the demise of capitalism. As a third constituent, the Jews were running from their memories of the ghettoes and from the reminder of the Ostjuden. ${ }^{16}$ These intellectuals placed their own personal vision of the "ideal" above all other social concerns in the form of the Enlightenment philosophes. Thus, the "third force" provided an escape from the modern capitalisticmaterialistic world into a fantasy world of ideal utopian societies.

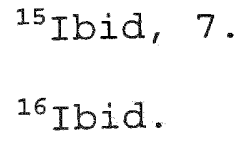


Although Mosse never mentions Karl Kraus by name, the latter does seem to share many of the very qualities and characteristics outlined by Mosse. Kraus himself retreated into a world of ideas and absolutes. His conception of the world was rooted in the purity of the German language and he envisioned an end to anti-Semitism through Jewish assimilation into a fantasy world of "enlightened" liberalism. Kraus vehemently attacked those with different perspectives, but always from the cultural ideal in which he found shelter from the anti-Semitic and materialist world of turn-of-the-century Vienna.

What separated Kraus from the conservative, fanatical anti-Semites was that they saw the negative characteristics of the Jews as being inherent, innate qualities of the Jewish "race." Kraus, on the other hand, regarded these same characteristics as negative, but as a condition of the Jews' ghetto heritage and history. They were the result of Jewish confinement to the ghettoes and the stigma of usury that stemmed from the medieval period. If Jews could only realize the nature of this obstacle and overcome it through the rejection of "Jewish solidarity" and "Jewish identity," the "Jewish Question" would be resolved, at least as Kraus saw the problem. Rather than attacking the negative, 
unsophisticated, stereotypical characteristics of the Ostjuden, who were just beginning to adapt to western society, Kraus focused his venom instead on the "flawed" and "inconsistent" assimilation of acculturated Jews. Believing themselves to be assimilated, these acculturated Jews were hiding behind a façade of aesthetically pleasing artistic, literary, and cultural ideals. If this invisible "ghetto" could be torn down, then the path towards assimilation - Der Weg ins Frei to use Schnitzler's phrase - would be opened for all Jews willing to reject their Jewish identity.

Kraus's conception of Judaism viewed it as an archaic system of beliefs; it held no power in an enlightened, rational world. For him, the renunciation of his Jewish identity was a simple choice, a step towards the assimilation into the liberal western society that he envisioned, but from which he was isolated as a consequence of his Jewish origin. In Kraus's mind, the "Jewish Question" remained because Jews wanted to remain Jews within a non-Jewish society. Thus, his solution was for complete rejection of all notions of Jewish identity and Jewish solidarity. 
Kraus's responses to anti-semitism and his views on the Jews and Jewish assimilation must be placed in the context of his Viennese environment. Kraus's hatred of "Jewish solidarity" and a particular "Jewish identity" were clearly a result of the extreme pressures exerted by Viennese society on its members to conform to its "Germanic ideal" and reject any variances. Kraus's revulsion of "Jewish" qualities was a reflection of the standard reaction of the non-Jewish intellectual elite. His own personal origins, however, made his a very dark reflection with regard to the Jews and the possibility of assimilation into Austro-German society.

One of Kraus's failings was that he severely underestimated the long-term power and effects of antiSemitism on Austro-German society in the aftermath of the First World war. In keeping with his early assessment, Kraus dismissed Judaism as an irrational, archaic, debased ideology that would eventually fade in the "late enlightenment" atmosphere of modernizing Vienna. Instead, Kraus turned his focus on the "Jewish" press, especially the Neue Freie Presse, as representing all the evils of Austrian society and the capitalist-materialist corruption of liberalism that he despised. 
Kraus's writings were not burned in the Nazi roundup of "degenerate" or "communist" (that is, "Jewish") works in 1933. After AnschIuß, however, Kraus's study in Vienna was "ransacked, his furniture smashed, his library and thousands of letters destroyed," along with his still unpublished translations of Shakespeare. ${ }^{17}$ Having died from a stroke on June 12, 1936, Kraus himself was spared this final injury.

So, in conclusion, was Kraus an example of a "Jewish self-hater" or an "Old Testament prophet"? It can be argued that both of these designations are inadequate. The qualities that Kraus seemed to exemplify are those of what can be termed a sort of "modern day prophet." Kraus was forced to respond to the multiple factors of his environment: virulent anti-Semitism, the demise of liberalism, the decay of the Habsburg Empire from within and without, modern capitalist-materialism, the rise of mass media, Zionism, and other social and cultural factors. As a result, Kraus created his own personal resolution to the "Jewish Question" through a radical assimilation and a rejection of his Jewish identity and the materialistic culture of modernity. These modern factors separate him

${ }^{17}$ Rosenfeld, "Karl Kraus: The Future of a Legacy," 77. 
from the sort of "Old Testament" category. However, Kraus was also attempting to revive western society and culture and secure a place for assimilation-seeking Jews within his ideal liberal world. His continual polemics, imploring his readers towards a "critical enlightenment," impart the quality of a tortured prophet to his writings. Thus, Kraus can be seen as a modern day prophet responding to society's obstacles through a linguistically pure world of his own creation. 


\section{Bibliography}

\section{Primary Sources:}

Benda, Julien. The Treason of the Intellectuals (La Trahison des Clercs). Translated by Richard Aldington. New York: W.W. Norton and Company, 1969. First published in 1928 .

Benjamin, Walter. Illuminationen. Frankfurt am Main: Suhrkamp Verlag, 1961.

Illuminations. Edited with an introduction by Hannah Arendt. Translated by Harry Zohn. New York: Harcourt, Brace, and World, 1968.

Bloch, Albert. German Poetry in War and Peace: Poems by Karl Kraus and Georg Trakl, with translations, paintings and drawings by Albert Bloch. Edited by Frank Baron. The Max-Kade Center for German-American Studies: University of Kansas, 1995.

Bettauer, Hugo. Die Stadt ohne Juden: ein Roman von übermorgen. Frankfurt am Main: Ullstein, 1988 .

Cannetti, Elias. The Torch in my Ear. Translated by Joachim Neugroschel. New York: Farrar, Straus, and Giroux, 1982 .

- The Conscience of Words. Translated by Joachim Neugroschel. New York: Seabury Press, 1979.

Gilman, Sander L., and Jack Zipes, eds. Yale Companion to Jewish Writing and Thought in German Culture, 10961996. New Haven: Yale University Press, 1997.

Jünger, Ernst. The Storm of Steel: from the diary of a German storm-troop officer on the Western Front. London: Chatto \& Windus, 1929. Reprint, New York: Howard Fertig, 1996. 
Kaes, Anton, Martin Jay, and Edward Dimendberg, eds. The Weimar Republic Sourcebook. Berkeley: University of California Press, 1994.

Kraus, Karl. Werke. Edited by Heinrich Fischer, 14 vols. (Munich: Kösel-Verlag, 1952-1967). Comprised of the following volumes:

I Die dritte Walpurgisnacht (1952)

II Die Sprache (1954)

II Beim Wort genommen (1955)

IV Widerschein der Fackel (1956)

$\mathrm{V}$ Die letzten Tage der Menschheit (1957)

VI Literatur und Lüge (1958)

VII Worte in Versen (1959)

VIII Untergang der Welt durch schwarze Magie (1960)

IX Unsterblicher Witz (1961)

X Mit vorzüglicher Hochachtung (1962)

XI Sittlichkeit und Kriminalität (1963)

XII Die chinesische Mauer (1964)

XII Weltgericht (1965)

XIV Dramen (1967)

- Die Fackel. München: Kösel-Verlag, 1968-1973.

- Die letzten Tage der Menschheit: Bühnenfassung des Autors. Herausgegeben von Eckart Früh. Frankfurt am Main: Suhrkamp Verlag, 1992.

- Frühe Schriften, 2 vols. Edited by Joh. J. Braakenburg. München: Kösel-Verlag, 1979.

- Half-Truths and one and a Half Truths: Karl Kraus, Selected Aphorisms. Edited and Translated by Harry Zohn. Montreal: Engendra Press, 1976.

In These Great Times: A Karl Kraus Reader. Edited by Harry Zohn. Translated by Joesph Farby, Max Knight, Karl F. Ross, and Harry Zohn. Montreal: Engendra Press, 1976.

No Compromise: Selected Writings of Karl Kraus. Edited by Frederick Ungar. Translated by Sheema $Z$. Buehne, Edward Mornin. Helene Jeher, Marcus Bullock, Michael Bullock, Frederick Ungar, and D.G. Wright. New York: Frederick Ungar Publishing, 1977. 
- The Last Days of Mankind: A Tragedy in Five Acts. Abridged and edited by Frederick Ungar.

Translated by Alexander Gode and Sue Ellen Wright. New York: Frederick Ungar Publishing, 1974.

Marx, Karl. "On the Jewish Question" in Early Writings. Translated by Rodney Livingstone and Gregor Benton. New York: Penguin Books, 1992.

Steed, Wickham. The Habsburg Monarchy. London, 1913. Quoted in Edward Timms, Karl Kraus, Apocalyptic Satirist: Culture and Catastrophe in Habsburg Vienna, New Haven: Yale University Press, 1986.

Twain, Mark. Concerning the Jews. Philadelphia: Running Press, 1985. First published in Harper's New Monthly Magazine, 1897.

. "Stirring Times in Austria." Harper's New Monthly Magazine (1897) : 540.

Wagner, Richard. "Judaism in Music" in Stories and Essays. Edited by Charles Osborne. London: Peter Owen, 1973.

Wassermann, Jacob. My Life as German and Jew. Translated by S.N. Brainin. New York: Coward-McCann, 1933.

Zweig, Stefan, The World of Yesterday. Lincoln and London: University of Nebraska Press, 1964. 


\section{Secondary Sources:}

Aberbach, Alan David. The Ideas of Richard Wagner: An Examination and Analysis of His Major Aesthetic, Political, Economic, Social, and Religious Thoughts. New York: University Press of America, 1984.

Adas, Michael. Machines as the Measure of Men: Science, Technology, and Ideologies of Western Dominance. Ithaca: Cornell University Press, 1989.

Arnold, Heinz Ludwig. Karl Kraus. München: Johannesdruck Hans Pribil KG, 1975.

Aschheim, Steven E. Brothers and Strangers: The East German Jew in German and German Jewish Consciousness, 1800-1923. Madison: University of Wisconsin Press, 1982 .

Culture and Catastrophe: German and Jewish Confrontations with National Socialism and other Crises. New York: New York University Press, 1996.

Beller, Steven. Francis Joseph. London and New York: Longman, 1996.

- Vienna and the Jews, 1867-1938. Cambridge: Cambridge University Press, 1989.

Blackbourn, David. The Long Nineteenth Century: A History of Germany, 1780-1918. Oxford: Oxford University Press, 1998.

Boyer, John W. "Karl Lueger and the Viennese Jews." In Leo Baeck Institute Year Book XXVI (1981) : 125-141.

Brenner, Michael and Derek J. Penslar, eds. In Search of Jewish Community: Jewish Identities in Germany and Austria, 1918-1933. Bloomington and Indianapolis: Indiana University Press, 1998.

Calleo, David. The German Problem Reconsidered: Germany and the World Order, 1870 to the Present. Cambridge: Cambridge University Press, 1978. 
Carlebach, Julius. Karl Marx and the Radical Critique of Judaism. London, Henley, and Boston: Routledge and Kegan Paul, 1978.

Červinka, Frantisěk. "The Hilsner Affair." In Leo Baeck Institute Year Book XIII (1968) : 142-157.

Cuddihy, John Murray. The Ordeal of Civility: Freud, Marx, Levi-Strauss, and the Jewish Struggle with Modernity. New York: Basic Books, 1974.

Daviau, Donald G. "Karl Kraus in English Translation." In The Psychoanalytic Review, edited by Marie Coleman Nelson and Murray H. Sherman. New York: Human Science Press, 1978.

Dundes, Alan, ed. The Blood Libel Legend: A Casebook in Anti-Semitic Folklore. Madison and London: University of Wisconsin Press, 1991.

Eksteins, Modris. Rites of Spring: The Great war and the Birth of the Modern Age. Boston: Houghton Mifflin Co., 1989.

Elias, Norbert. The Civilizing Process: Sociogenic and Psychogenic Investigations. Translated by Edmund Jephcott. Edited by Eric Dunning, Johan Goudsblom, and Stephen Mennell. Oxford: Blackwell Publishers, 2000 .

Field, Frank. The Last Days of Mankind: Karl Kraus and his Vienna. New York: St. Martin's Press, 1967.

Fischer, Fritz. Germany's Aims in the First world War. New York: W.W. Norton and Company, 1967.

Fischer, Heinrich. "The Other Austria and Karl Kraus." In Tyrannos: Four Centuries of Struggle Against Tyranny in Germany. Edited by Hans J. Rehfisch. London: Lindsay Drummond, 1944.

Flügel-Schmidt-Tanger, wörterbuch der Englischen und Deutschen Sprache. Bearbeitet von Prof. Dr. Im. Schmidt und Dr. G. Tanger. Achte Auflage. Berlin: George Westermann, 1914. 
Fraenkel, Josef, ed. The Jews of Austria. London: Valentine, Mitchel1, \& Co., 1967.

Frankel, Jonathan. The Damascus Affair: "Ritual Murder," Politics, and the Jews in 1840. Cambridge University Press, 1997.

Frankel, Johnathan and Steven J. Zipperstein, eds. Assimilation and Community: The Jews in nineteenthcentury Europe. Cambridge: Cambridge University Press, 1992 .

Furguson, Niall. The Pity of War. New York: Basic Books, 1999.

Fussell, Paul. The Great War and Modern Memory. Oxford: Oxford University Press, 1975.

Gay, Peter. Freud, Jews, and Other Germans: Masters and Victims in Modernist Culture. New York: Oxford University Press, 1978.

Gilman, Sander L. Jewish Self-Hatred: Anti-Semitism and the Hidden Language of the Jews. Baltimore: Johns Hopkins University Press, 1986.

- The Jew's Body. New York: Routledge, 1991.

Goldberg, David Theo and Michael Krausz, eds. Jewish Identity. Philidelphia: Temple University Press, 1993.

Grimstad, Keri. Masks of the Prophet: The Theatrical World of Karl Kraus. Toronto: University of Toronto Press, 1982 .

Gruber, Helmut. "Red Vienna and the "Jewish Question"." In Leo Baeck Institute Year Book XXXVIII (1993) : 99118 .

Grunberger, Richard. "Jews in Austrian Journalism." In The Jews of Austria: Essays on their Life, History and Destruction, ed. Josef Fraenkel, (83-95). London: Mitchell \& Co., 1967. 
Halliday, John D. Karl Kraus, Franz Pfemfert and the First World War: A Comparative study of Die Fackel and Die Aktion between 1911-1928. Passau: Andreas-HallerVerlag, 1986.

Hamann, Brigitte. Hitler's Vienna: A Dictator's Apprenticeship. Translated by Thomas Thornton. Oxford: Oxford University Press, 1999.

Harrowitz, Nancy and Barbara Hyams, eds. Jews and Gender: Responses to Otto Weininger. Philidelphia: Temple University Press, 1995.

Heller, Erich. In the Age of Prose. New York: Cambridge University Press, 1984.

The Disinherited Mind: Essays in Modern German Literature and Thought. New York: Farrar, Straus, and Cudahy, 1957.

Hertzberg, Arthur, ed. The Zionist Idea: A Historical Analysis and Reader. New York: Atheneum, 1959.

Horne, Jon and Alan Kramer. "German 'Atrocities' and France-German Opinion, 1914: The Evidence of German Soldiers' Diaries." Journal of Modern History 66 (March 1994) : $1-33$.

Horak, Roman, Wolfgang Maderthaner, Siegfried Mattl, Gerhard Meissl, Lutz Musner, and Alfred Pfoser, eds. Metropole Wien: Texturn der Moderne, 2 vols. Wein: Universitätsverlag, 2000.

Iggers, Georg G. The German Conception of History: The National Tradition of Historical Thought from Herder to the Present. Middletown (CT): Wesleyan University Press, 1968.

Iggers, Wilma Abeles. "Karl Kraus and his Critics." Modern Austrian Literature 8 (1975) : 26-47.

Karl Kraus: A Viennese Critic of the Twentieth Century. The Hauge: Martinus Nijhoff, 1967.

Janik, Allan and Stephen Toulmin. Wittgenstein's Vienna. New York: Simon and Schuster, 1973. 
Jones, Gail Sarah. "Karl Kraus's Die letzten Tage der Menschheit: Language as the Despair and Hope of Man." Master's Thesis, State University of New York at Stoney Brook, 1976.

Johnston, William M. The Austrian Mind: An Intellectual and Social History, 1848-1938. Berkeley: University of California Press, 1972.

Kann, Robert A. A History of the Habsburg Empire, 15261918. Berkeley: University of California Press, 1974 .

- "German-Speaking Jewry During Austria-Hungary's Constitutional Era (1867-1918)." Jewish Social Studies $X$ (July 1948) : 239-256.

Kann, Robert A., Béla K. Király, Paula S. Fichtner, eds. The Habsburg Empire in World War I: Essays on the Intellectual, Military, Political, and Economic Aspects of the Habsburg War Effort. New York: Columbia University Press, 1977.

Katz, Jacob. From Prejudice to Destruction: Anti-Semitism, 1700-1933. Cambridge: Harvard University Press, 1980 .

Kohn, Caroline. "Die Wiener jüdische Jargon im Werke von Karl Kraus." Modern Austrian Literature 8 (1975) : $240-267$.

Lasswell, Harold. Propaganda Technique in the First World War. New York: Garland Publishing, 1972. Reprint of 1938 edition. First published in 1927.

Leed, Eric J. No Man's Land: Combat and Identity in World War I. Cambridge: Cambridge University Press, 1979.

Le Rider, Jacques. Modernity and Crises of Identity: Culture and Society in Fin-de-Siècle Vienna. Translated by Rosemary Morris. New York: Continuum, 1993.

Lessing, Theodor. Der jüdische Selbsthaß. Berlin: Jüdischer Verlag, 1930. 
Liegler, Leopold. Karl Kraus und sein Werk. Vienna: Richard Lanyi, 1920.

Marek, George R. The Eagles Die: Franz Joseph, Elisabeth, and their Austria. New York: Harper and Row, 1974.

Mason, John W. The Dissolution of the Austro-Hungarian Empire, 1867-1918, $2^{\text {nd }}$ ed. London and New York: Longman, 1997.

Mayer, Sigfried. Die Wiener Juden: Kommerz, Kultur, Politik, 1700-1900. Wein und Berlin: R. Lömit Verlag, 1918.

McKittrick, Brigid Mary Ursula. Women-The Borderline Case: Karl Kraus and the Role of Women in turn of the century Vienna. Ph.D diss, University of Exeter, 1987.

Mendelsohn, Ezra. On Modern Jewish Politics. Oxford: Oxford University Press, 1993.

Merriman, John. A History of Modern Europe, vol. 2. New York: W.W. Norton and Company, 1996.

Mosse, George L. German Jews Beyond Judaism. Bloomington: Indian University Press, 1985.

- Germans and Jews: The Right, the Left, and the Search for a "Third Way" in pre-Nazi Germany. New York: Howard Fertig, 1970.

Muller, Ulrich and Peter Wapnewski, eds. Wagner Handbook. Translated by John Deathridge. Cambridge, Mass: Harvard University Press, 1992.

Neumarkt, Paul. "Kraus, Tucholsky, Felix Mendelssohn: A Trio of Apostates." Jewish Currents 27 (December 1973) : $37-45$.

Oxaal, Ivar, Michael Pollack, and Gerhard Botz, eds. Jews, Anti-Semitism and Culture in Vienna. London: Routledge and Kegan Paul, 1987.

Oxaal, Ivar and Walter R. Weitzmann. "The Jews of Pre-1914 Vienna: An Exploration of Basic Sociological 
Dimensions." In Leo Baeck Institute Year Book XXX (1985) : 395-432.

Pauley, Bruce F. From Prejudice to Persecution: A History of Austrian Anti-Semitism. Chapel Hill: University of North Carolina Press, 1992.

Prawer, S.S. "Jewish Contributions to German Lyric Poetry." In Leo Baeck Institute Year Book VIII (1963) : $149-170$.

Proctor, Robert N. Value-Free Science? Purity and Power in Modern Knowledge. Cambridge: Harvard University Press, 1991.

Pulzer, P.G.J. "The Austrian Liberals and the Jewish Question." Journal of Central European Affairs XXIII (July 1963) : 131-142.

- The Rise of Political Anti-Semitism. New York, London: John Wiley and Sons, 1964.

Pynsent, Robert B., ed. T.G. Masaryk (1850-1937) Volume 2 Thinker and Critic. New York: St. Martin's Press, 1989 .

Robertson, Ritchie. The "Jewish Question" in German Literature, 1749-1939. Oxford: Oxford University Press, 1999.

"The Problem of 'Jewish Self-hatred' in Herzl, Kraus and Kafka." Oxford German Studies 14 (1985) : 92-99.

Rosenfeld, Sidney. "Karl Kraus: The Future of a Legacy." Midstream (April 1974) : 71-80.

Rosensaft, Menachem $z$. "Jews and Antisemites in Austria at the End of the Nineteenth Century." In Leo Baeck Institute Year Book, 21 (1976) ed. Arnold Paucker. London: Martin Secker and Warburg, 1982.

Roshwald, Aviel and Richard Stites, eds. European Culture in the Great War: The Arts, Entertainment, and Propaganda, 1914-1918. Cambridge: Cambridge University Press, 1999. 
Rozenbilt, Marsha L. The Jews of Vienna, 1867-1914.

Albany: State University of New York Press, 1983.

Ruppin, Arthur. The Jews in the Modern World. New York: Macmillan and Co., 1934. Reprint New York: Arno Press, 1973.

- The Jews of To-DaY. Translated by Margery

Bentwich. New York: Henry Holt, 1913.

Scheu, Robert. Karl Kraus. Vienna: Jahoda \& Siegel, 1909 .

Schorske, Carl E. Fin-de-Siècle Vienna: Politics and Culture. New York: Vintage Books, 1981.

Schwarz, Egon. Poetry and Politics in the Works of Rainer Maria Rilke. Translated by David E. Wellbery. New York: Frederick Ungar Publishing, 1981.

Segel, Harold B. The Viennese Coffeehouse Wits, I8901938. West Lafayette: Purdue University Press, 1993.

Sengoopta, Chandak. Otto Weininger: Sex, Science, and Self in Imperial Vienna. Chicago: Chicago University Press, 2000 .

Sherman, Murray H., ed. Psychoanalysis and old Vienna: Freud, Reik, Schnitzler, Kraus. New York: Human Sciences Press, 1978.

Snell, Mary. "Karl Kraus's The Last Days of Mankind." Forum for Modern Language Studies 4 (July 1968) : $234-237$.

Spalter, Max. Brecht's Tradition. Baltimore: The Johns Hopkins Press, 1967.

Stern, J. P. "Karl Kraus's Vision of Language." Modern Language Review 61 (January 1966) : 71-84.

"Words Are Also Deeds: Some Observations on Austrian Language Consciousness." New Literary History 12 (1981) : 509-528. 
Steiner, George. "Karl Kraus: Fear and Loathing in

Vienna" London Sunday Times. 12 August 1984, p. 39.

Stonequist, Everett V. The Marginal Man: A Study in Personality and Culture Conflict. New York: Charles Schribner and Sons, 1937. Reprint, New York: Russel1 \& Russe11, 1961.

Szasz, Thomas. Anti-Freud: Karl Kraus's Criticism of Psychoanalysis and Psychiatry. Baton Rouge:

Louisiana State University Press, 1976. Reprint, Syracuse University Press, 1990.

Theobald, John. The Paper Ghetto: Karl Kraus and AntiSemitism. Frankfurt am Main: Peter Lang, GmbH, 1996.

Thon, Jakob. Die Juden in Österreich. Berlin: Halensee, 1908 .

Thornhill, C.J. Walter Benjamin and Karl Kraus: Problems of 'Wahlverwandtschaft'. Stuttgart: Heinz, 1996.

Timms, Edward. Karl Kraus, Apocalyptic Satirist: Culture and Catastrophe in Habsburg Vienna. New Haven: Yale University Press, 1986.

"The Last Days of Mankind: A Neglected Play." Times (London). 22 June $1964, \mathrm{p} .14$.

Toury, Jacob. "Troubled Beginnings: The Emergence of the Österreichisch-Israelitische Union." In Leo Baeck Institute Year Book XXX (1985) : 457-475.

Viertel, Berthold. Karl Kraus: Ein Charakter und die zeit. Dresden: Kämerer, 1921.

Volkov, Shulamit. "Antisemitism as a Cultural Code: Reflections on the History and Historiography of Antisemitism in Imperial Germany." In Leo Baeck Institute Year Book XXIII (1978): 25-46.

Waterman, John T. A History of the German Language, revised edition. Washington: University of Washington Press, 1966. Reprint Prospect Heights (IL): Waveland Press Inc., 1991. 
Weiner, Marc. Richard Wagner and the Anti-Semitic Imagination. Lincoln: University of Nebraska Press, 1997.

Wertheimer, Jack. Unwelcome strangers: East European Jews in Imperial Germany. Oxford: Oxford University Press, 1987.

Whiteside, Andrew G. The Socialism of Fools: Georg Ritter von Schönerer and Austrian Pan-Germanism. Berkeley, Los Angeles, London: University of California Press, 1975 .

Willams, Cedric E. The Broken Eagle: The Politics of Austrian Literature from Empire to Anschluss. New York: Barnes and Noble, 1974.

Wistrich, Robert S. "Austrian Social Democracy and the Problem of Galician Jewry, 1890-1914." In Leo Baeck Institute Year Book XXVI (1981) : 89-124.

- Between Redemption and Perdition: Modern AntiSemitism and Jewish Identity. London and New York: Routledge, 1990.

- "Karl Kraus: Jewish Prophet or Renegade?" European Judaism 9 (Summer 1975) : 32-38.

- Socialism and the Jews: The Dilemmas of Assimilation in Germany and Austria-Hungary. London and Toronto: Associated University Presses, 1982.

- The Jews of Vienna in the Age of Franz Joseph. Oxford: Oxford University Press, 1989.

Zohn, Harry. Karl Kraus. New York: Twayne Publishers, 1971 .

Karl Kraus and the Critics. Columbia: Camden House, 1997.

"Karl Kraus: "Jüdischer Selbsthasser " oder "Erzjude"?" Modern Austrian Literature 8 (1975) : 119. 
"Krausiana: Karl Kraus in English Translation; current criticism of Karl Kraus." Modern Austrian Literature III (1970) : 25-35.

- "Stefan Zweig, the European and the Jew." In Leo Baeck Institute Year Book, 27 (1982) ed. Arnold Paucker. London: Martin Secker and Warburg, 1982.

- "The Stature of Karl Kraus." Midstream (March 1986) : $42-48$. 
"Krausiana: Karl Kraus in English Translation; current criticism of Karl Kraus." Modern Austrian Literature III (1970): 25-35.

- "Stefan Zweig, the European and the Jew." In Leo Baeck Institute Year Book, 27 (1982) ed. Arnold Paucker. London: Martin Secker and Warburg, 1982.

- "The Stature of Karl Kraus." Midstream (March 1986) : $42-48$. 